\title{
Visible-Light-Mediated Alkylation of Thiophenols via Electron Donor-Acceptor Complexes Formed between Two Reactants
}

\author{
Yi-Ping Cai, Fang-Yuan Nie and Qin-Hua Song* \\ Department of Chemistry, University of Science and Technology of China, Hefei 230026, P. R. China. \\ E-mail: qhsong@ustc.edu.cn
}

\section{Contents}

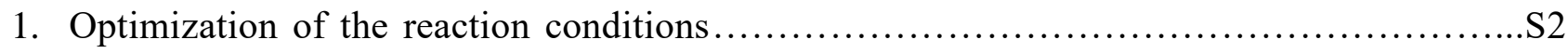

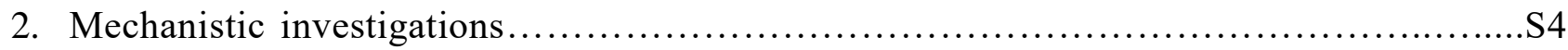

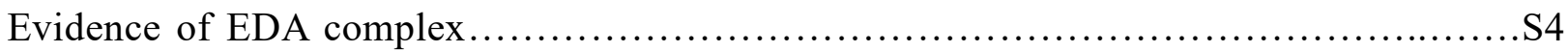

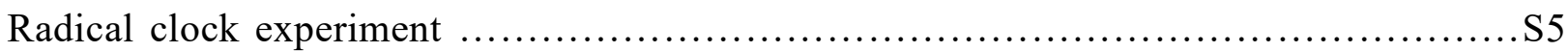

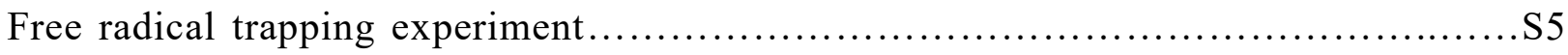

Direct reaction with the thiophenol anion in the absence of a base.......................S7

Measurements of the quantum yield for the synthesis reaction............................ 7

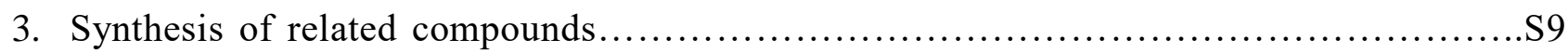

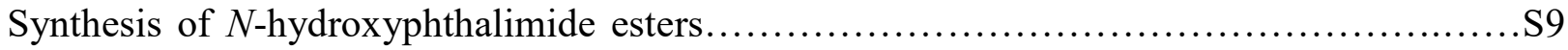

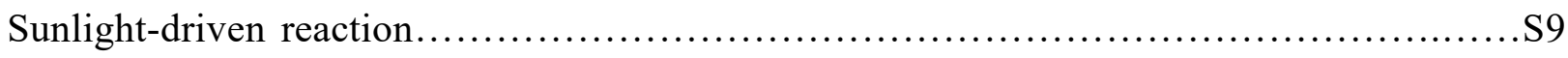

4. Copies for NMR spectra of related compounds.................................. $10-42$ 


\section{Optimization of the reaction conditions}

Table S1. Optimization of the decarboxylative arylthiation conditions

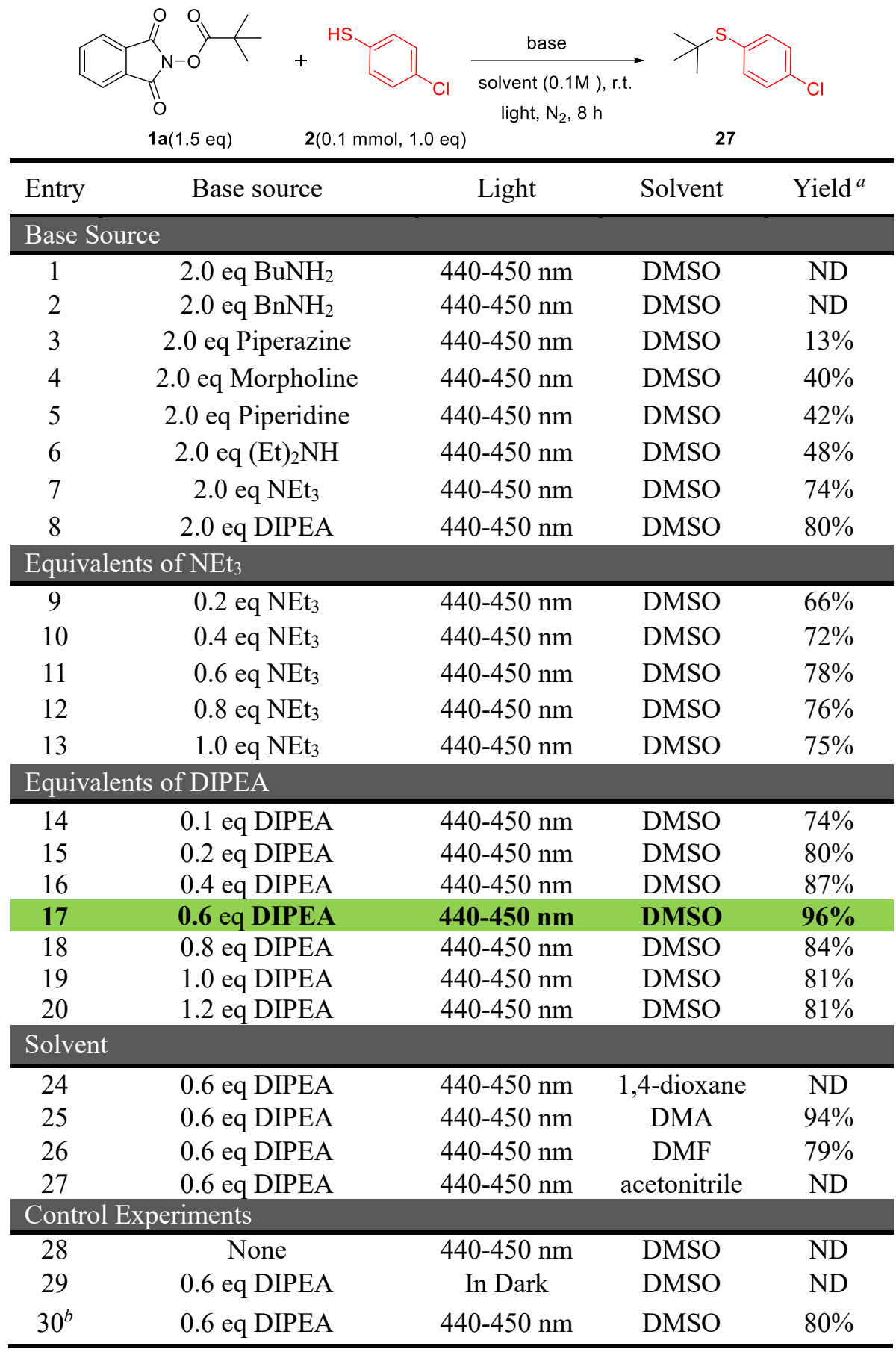

${ }^{a}$ All experiments were performed on a $0.1 \mathrm{mmol}$ scale in $1.0 \mathrm{~mL}$ of solvent $(0.1 \mathrm{M})$ and yields were determined by ${ }^{1} \mathrm{H}$ NMR analysis using 1,3,5-trimethoxybenzene as internal standards. ${ }^{b}$ In air. ND = not detected. 


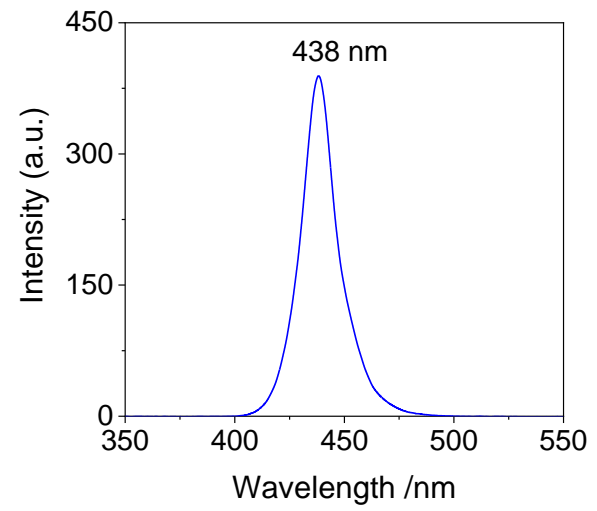

Figure S1. The luminescence spectrum of the blue light lamp used in this work. 


\section{Mechanistic investigations}

- UV-vis Absorption Spectra<smiles>CC(C)(C)C(=O)ON1C(=O)c2ccccc2C1=O</smiles>

$1 \mathrm{a}, 1.5 \mathrm{eq}$

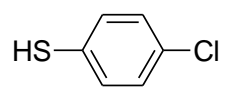

2, $1.0 \mathrm{eq}$<smiles>CCN(C(C)C)C(C)C</smiles>

DIPEA, 0.6 eq

Stock solutions of 1a, $\mathbf{2}$ or DIPEA were prepared at the same ratio as in the reaction. The solutions were prepared in DMSO.
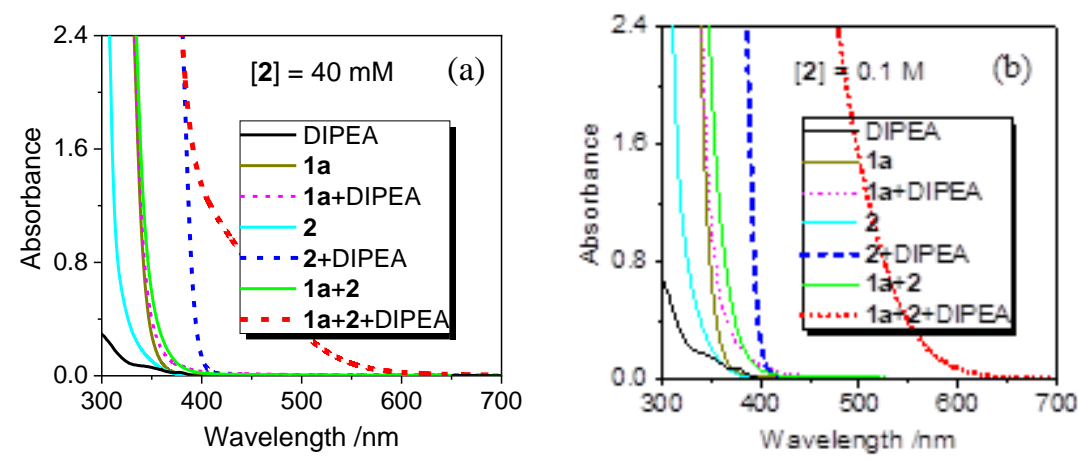

(c)

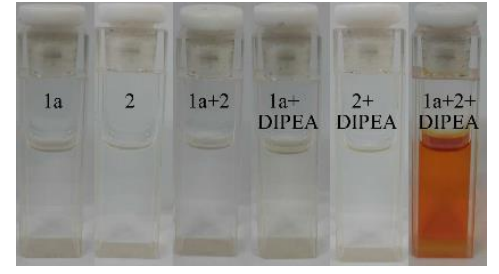

Figure S2. UV/vis absorption spectra of 2 in (a) $40 \mathrm{mM}$ or (b) $0.1 \mathrm{M}$ solutions without or with 1a or/and DIPEA, in DMSO, and (c) photos of various solutions from (b).

\section{- Determination of the association constant $\left(K_{E D A}\right)$ of $1 \mathbf{a}$ and deprotonated 2}

The partial ${ }^{1} \mathrm{H}$ NMR $\left(500 \mathrm{MHz}, d_{6}\right.$-DMSO) of $p$-chlorothiophenol $2(50 \mathrm{mM}, 1.0 \mathrm{eq})+1 \mathrm{a}(75 \mathrm{mM}, 1.5 \mathrm{eq})+$ DIPEA $(30 \mathrm{mM}, 0.6 \mathrm{eq})$ is as follows:

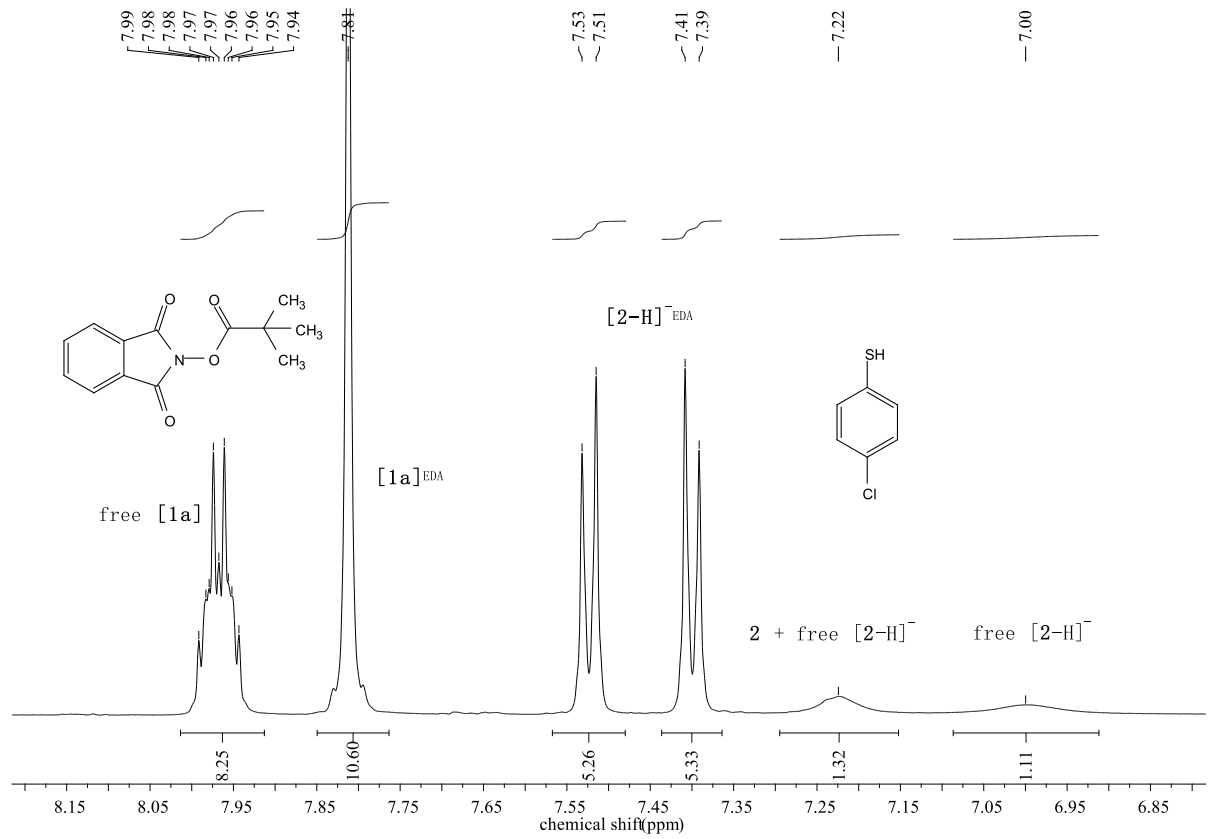

In this NMR spectrum, the peaks which are assigned to the parts in the EDA complex and those to the free 
molecules are observed individually in the same NMR spectrum. Those peaks appear at individual chemical shifts, and so it is suitable for the measurement by NMR spectroscopy to evaluate the equilibrium constant of the EDA complex.

In the experimental condition, NMR sample solutions were prepared, total concentration of $1 \mathbf{a},[1 a]_{0}=0.075 \mathrm{M}$; total concentration of $\mathbf{2},[2]_{0}=0.05 \mathrm{M}$. From the NMR spectral data, the peaks that are assigned to free 1a and 1a in EDA, are observed individually with the integration ratio 8.25 to 10.60 . In the same manner, the peaks that are assigned to free $[\mathbf{2}-\mathrm{H}]^{-}$and $[\mathbf{2}-\mathrm{H}]^{-}$in EDA complex, are observed individually with the integration ratio 1.11 to 5.33 .

$\because \frac{[1 a]_{E D A}}{[1 a]_{0}}=\frac{[1 a]_{E D A}}{[1 a]+[1 a]_{E D A}}=\frac{10.60}{8.25+10.60}$

$\therefore[1 a]_{E D A}=\frac{10.60}{8.25+10.60} \times[1 a]_{0}=0.042 \mathrm{M}$

Thus, the concentration of free $1 \mathrm{a},[1 \mathrm{a}]=[1 \mathrm{a}]_{0}-[1 a]_{E D A}=0.033 \mathrm{M}$

$\frac{[1 a]_{E D A}}{[2-H]^{-} E D A}=\frac{10.60 \div 4}{5.33 \div 2}=0.99$

This result supports that the stoichiometry is $1: 1$ for $\mathbf{1 a}$ and $[2-\mathrm{H}]^{-}$in the EDA complex, so the concentration of the EDA complex $[\mathrm{EDA}]$ can be defaulted to the concentration of $\mathbf{1 a}$ in the EDA complex, $[\mathbf{1 a}]_{\mathrm{EDA}}$, i.e., $[\mathrm{EDA}]=[\mathbf{1 a}]_{\mathrm{EDA}}$.

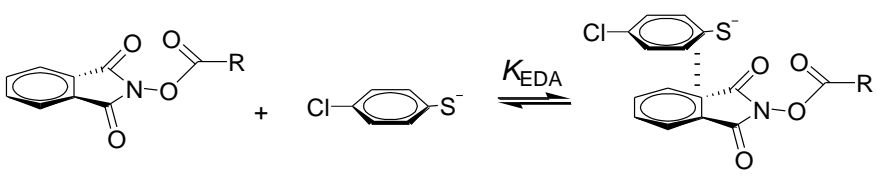

1a $[2-\mathrm{H}]^{-} \quad$ EDA complex

Thus, $K_{E D A}=\frac{[\mathrm{EDA}]}{[1 a][2-H]^{-}}=\frac{[1 a]_{E D A}}{[1 a][2-H]^{-}}=\frac{10.60 \div 4}{0.033 M \times 1.11 \div 2}=145 \mathrm{M}^{-1}$

\section{- Radical clocks experiment}

NHPI esters 11 ( $0.3 \mathrm{mmol}, 1.5$ equiv) and $\mathbf{2}(0.2 \mathrm{mmol}, 1.0$ equiv) were added to a $10 \mathrm{~mL}$ transparent Schlenk tube equipped with a stirring bar. The tube was evacuated and refilled with nitrogen $\left(\mathrm{N}_{2}\right)$ three times. Then DIPEA $(0.12 \mathrm{mmol}, 0.6$ equiv) and anhydrous DMSO $(2 \mathrm{~mL})$ were added via a gastight syringe under nitrogen atmosphere. Afterwards, the tube was sealed, and the reaction mixture was stirred under irradiation with blue LED (440-450 nm, distance approximately $3.0 \mathrm{~cm}$ from the lamp) at room temperature for $8 \mathrm{~h}$. Compound $\mathbf{1 5}$ in the yield of $54 \%$ was separated from the reaction mixture, and no the desired product with cyclopropylmethyl group was detected.

\section{- Free radical-trapping experiment}

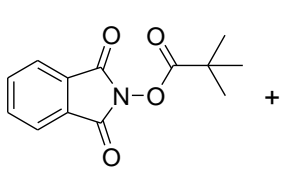

1a (1.5 eq)

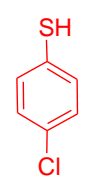

$2(0.1 \mathrm{mmol}, 1.0 \mathrm{eq})$

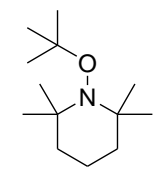

$58 \%$

Calcd for $\mathrm{C}_{13} \mathrm{H}_{27} \mathrm{NO}$ $[\mathrm{M}+\mathrm{H}]^{+}: 214.2165$ Found: 214.21661

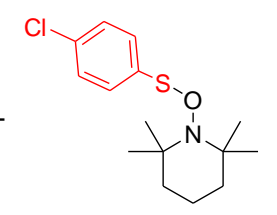

Calcd for $\mathrm{C}_{15} \mathrm{H}_{22} \mathrm{NOSCl}$ $[\mathrm{M}+\mathrm{H}]^{+}: 300.1183$ Found: 300.11838

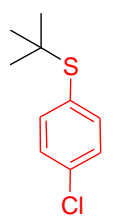

27, Not dectected 
NHPI ester 1a (0.15 mmol, 1.5 equiv), 2 ( $0.1 \mathrm{mmol}, 1.0$ equiv) and TEMPO (0.2 mmol, 2.0 equiv) were added to a $10 \mathrm{~mL}$ transparent Schlenk tube equipped with a stirring bar. The tube was evacuated and refilled with nitrogen $\left(\mathrm{N}_{2}\right)$ three times. Then, DIPEA $(0.06 \mathrm{mmol}, 0.6$ equiv) and anhydrous DMSO $(1 \mathrm{~mL})$ were added via a gastight syringe under nitrogen atmosphere, and the tube was sealed and the mixture was stirred under irradiation with blue LED (440-450 $\mathrm{nm}$, distance approximately $3.0 \mathrm{~cm}$ from the lamp) at room temperature for $8 \mathrm{~h}$. The reaction mixture was analyzed by HRMS with ESI source, no desired product 27 was detected, indicating that the reaction was completely inhibited by TEMPO. Meanwhile, free radical-trapping adducts of tert-butoxy radical with TEMPO and 4-chlorobenzene thiophenol radical with TEMPO were observed with HRMS analysis of the reaction solution at $\mathrm{m} / \mathrm{z} 214.21661$ and 300.11838 respectively (Figure S3). The yield of the former was $58 \%$ by ${ }^{1} \mathrm{H}$ NMR analysis using 1,3,5-trimethoxybenzene as internal standards.

$183-12: 1206$ RT: 3.42 AV: 1 NL: 1.38 E7
T:FTMS + p ESI Full ms [190.0000-350.0000]

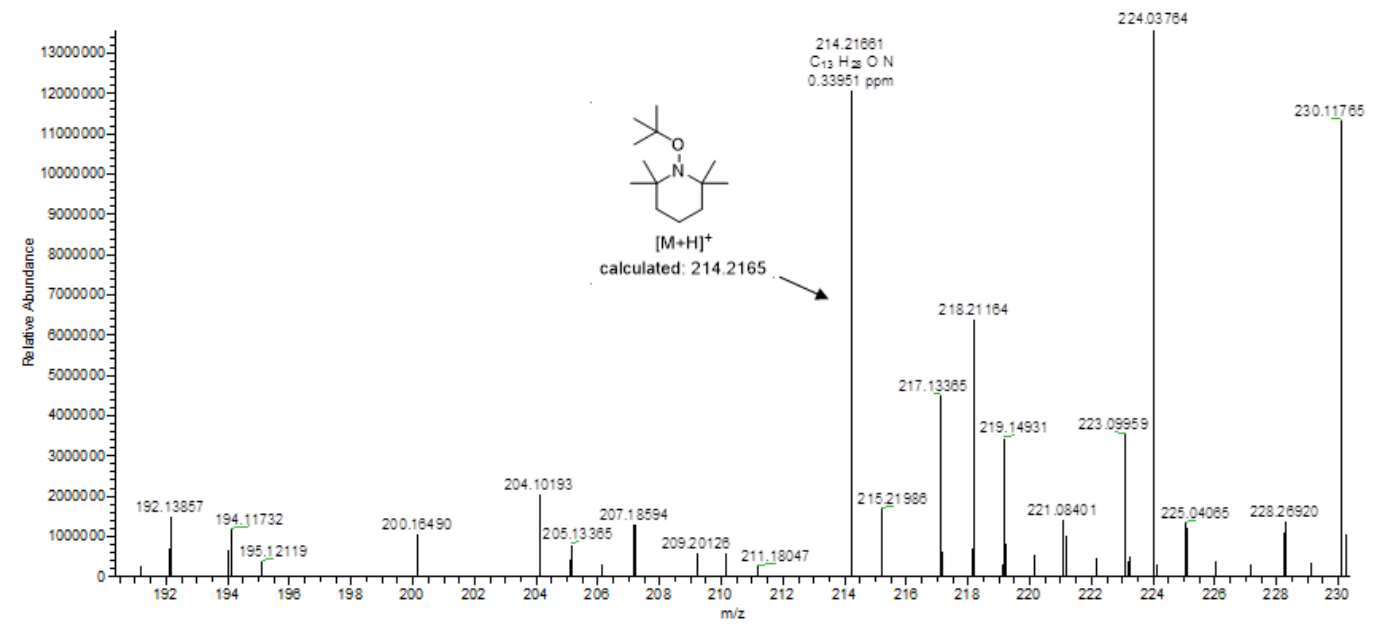

183-12 1208 RT: 3.42 AV: $1 \quad \mathrm{NL}: 4.45 \mathrm{E} 7$
T: FTMS + p ESI Full ms [190.0000-350.0000]

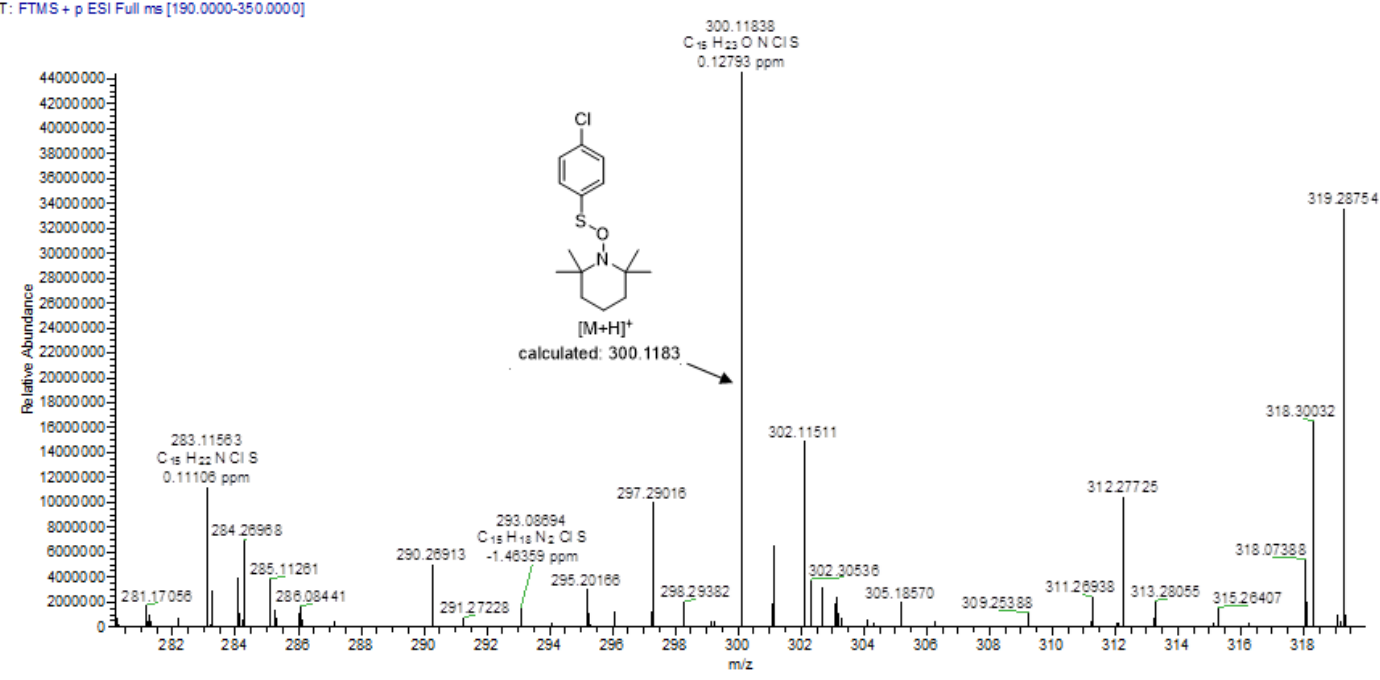

Figure S3. HRMS analysis of free radical-trapping adducts with TEMPO. 


\section{- Direct reaction with the thiophenol anion in the absence of a base}

Because DMSO-insolubility of the sodium salt caused the reaction not to proceed, the reaction was performed in DMA. NHPI ester 1a $(0.15 \mathrm{mmol}, 1.5$ equiv) and sodium 4-chlorothiophenolate $(0.1 \mathrm{mmol}, 1.0$ equiv) were added to a $10 \mathrm{~mL}$ transparent Schlenk tube equipped with a stirring bar. The tube was evacuated and refilled with nitrogen $\left(\mathrm{N}_{2}\right)$ three times. Then anhydrous DMA $(1 \mathrm{~mL})$ was added via a gastight syringe under nitrogen atmosphere, and the tube was sealed with ultrasonic treatment for 15 minutes to promote the solubility of reactants. The reaction mixture was stirred under irradiation with the blue light at room temperature for $8 \mathrm{~h}$, and then washed with water and extracted with ethyl acetate $(3 \times 10 \mathrm{~mL})$ to remove DMSO. The organic layers were combined and concentrated under reduced pressure for ${ }^{1} \mathrm{H}$ NMR analysis with 1,3,5-trimethoxybenzene as internal standards.

\section{- Quantum yield measurements}

The quantum yield of the reaction was measured by chemical actinometry using $\lambda$ max $=438 \mathrm{~nm}$ blue LEDs using potassium ferrioxalate following the procedure of J. N. Demas (J. Phys. Chem. 1981, 85, 2766), Yao Fu (Science 2019, 363, 1429) and F. Glorius (Org. Lett. 2018, 20, 1546).

$0.737 \mathrm{~g}$ of potassium ferrioxalate trihydrate was dissolved in $10 \mathrm{~mL} \mathrm{H}_{2} \mathrm{SO}_{4}(0.05 \mathrm{M})$ and stored in the dark. Then, a buffer solution was prepared by dissolving $2.5 \mathrm{~g}$ of sodium acetate and $0.5 \mathrm{~mL}$ of $\mathrm{H}_{2} \mathrm{SO}_{4}(98 \%)$ in $50 \mathrm{~mL}$ of distilled water.

General Protocol to assess the photon flux of the $438 \mathrm{~nm}$ blue LEDs:

To a $10 \mathrm{~mL}$ Schlenk flask containing a stirring bar, $1 \mathrm{~mL}$ of the actinometer solution was added. Then, the solution was irradiated for $60 \mathrm{~s}$. Immediately, a $100 \mu \mathrm{L}$ aliquot was taken and added to a $10 \mathrm{~mL}$ volumetric flask containing $15 \mathrm{mg}$ of 1, 10-phenanthroline in $3 \mathrm{~mL}$ of the buffer solution. The flask was filled with distilled water. The absorbance of this solution was then measured at $510 \mathrm{~nm}$ by UV/vis spectrophotometry. In a similar manner, this procedure is repeated with the actinometer solution stored in the dark. Using then the Beer's Law, the number of moles of $\mathrm{Fe}^{2+}$ produced by light irradiation is obtained by:

$$
\operatorname{mol}\left(F e^{2+}\right)=\frac{v_{1} v_{3} \Delta A(510 \mathrm{~nm})}{10^{3} v_{2} l \varepsilon(510 \mathrm{~nm})}=\frac{1 \mathrm{~mL} \times 10 \mathrm{~mL} \times 2.95}{10^{3} \times 0.100 \mathrm{~mL} \times 1 \mathrm{~cm} \times 11100 \mathrm{~mol}^{-1} \mathrm{~cm}^{-1}}=2.66 \times 10^{-5} \mathrm{~mol}
$$

Where:

$\mathrm{v}_{1}=$ Irradiated volume $(1 \mathrm{~mL})$.

$\mathrm{v}_{2}=$ The aliquot of the irradiated solution taken for the estimation of $\mathrm{Fe}^{2+}$ ions $(0.100 \mathrm{~mL})$.

$\mathrm{v}_{3}=$ Final volume of the solution after complexation with 1, 10-phenanthroline $(10 \mathrm{~mL})$.

$\varepsilon(510 \mathrm{~nm})=$ Molar extinction coefficient of $\left[\mathrm{Fe}(\mathrm{Phen})_{3}\right]^{2+}$ complex $\left(11100 \mathrm{~L} \mathrm{~mol}^{-1} \mathrm{~cm}^{-1}\right)$.

$1=$ Optical path-length of the cuvette $(1 \mathrm{~cm})$.

$\Delta \mathrm{A}(510 \mathrm{~nm})=$ absorbance difference between the irradiated solution and the solution stored in dark (2.95).

The photon flux (F) is obtained by using the following equation:

$$
\Phi(\lambda)=\frac{\operatorname{mol}\left(F e^{2+}\right)}{F\left(1-10^{-A(\lambda)}\right) t}
$$

Where:

$\Phi(\lambda)=$ The quantum yield for $\mathrm{Fe}^{2+}$ formation at $438 \mathrm{~nm}$ is $1.01 . \mathrm{A}(\lambda)=$ ferrioxalate actinometer absorbance at 438 $\mathrm{nm}$, which was measured placing $1 \mathrm{~mL}$ of the solution in a cuvette of path length $1 \mathrm{~cm}$ by UV/vis spectrophotometry. We obtained an absorbance value of 2.32. $t=$ is the reaction time (60 s). The photon flux (F) is $4.41 \times 10^{-7}$ einsteins/s. 


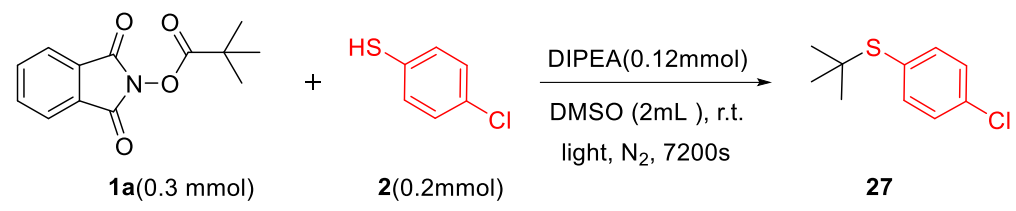

To obtain the quantum yield $(\Phi)$ of the decarboxylative arylthiation. The number of moles of the product $\mathbf{2 7}$ were determined by ${ }^{1} \mathrm{H}-\mathrm{NMR}$ analysis using 1,3,5-trimethoxybenzene as internal standard. As such, a photocatalytic reaction was performed under the set of optimized reaction conditions under visible light irradiation of $438 \mathrm{~nm}$ blue LEDs. After $7200 \mathrm{~s}$ of light irradiation, $1.67 \times 10^{-4}$ moles of 27 were obtained. The quantum yield of this reaction was calculated using the following equation:

$$
\Phi(438 \mathrm{~nm})=\frac{\text { mol of product }}{F\left(1-10^{-A(438 n m)}\right) t}=\frac{1.67 \times 10^{-4} \mathrm{~mol}}{4.41 \times 10^{-7}{\text { einsteins } \mathrm{s}^{-1} \times\left(1-10^{-4.12}\right) \times 7200 \mathrm{~s}}^{2}}=0.053
$$

Where:

$\mathrm{A}(438 \mathrm{~nm})=$ is the absorbance at $438 \mathrm{~nm}$ of the photocatalytic reaction which was measured placing $1 \mathrm{~mL}$ of the solution in a cuvette of path length $1 \mathrm{~cm}$ by UV/vis spectrophotometry (4.12).

$t=$ is the reaction time $(7200 \mathrm{~s})$.

The quantum yield $(\Phi)$ of the reaction is 0.053 . 


\section{Synthesis of related compounds}

- Synthesis of N-hydroxyphthalimide (NHPI) esters
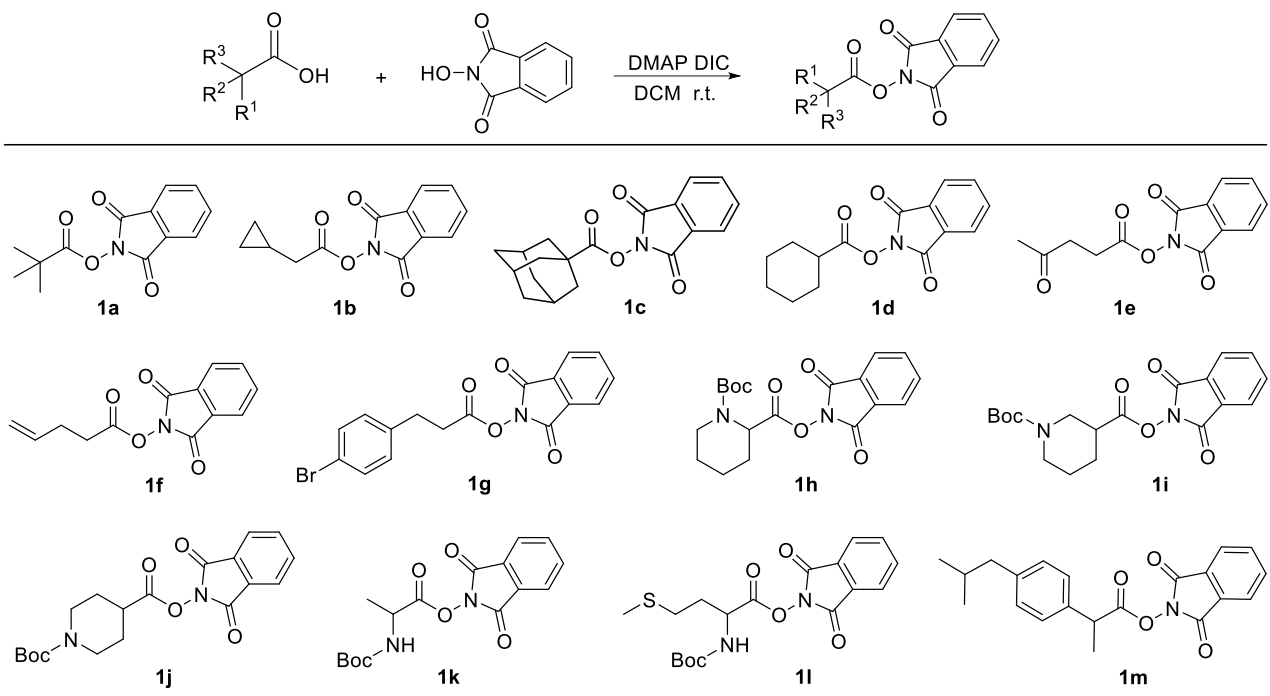

Chart S1. Synthesis of NHPI active esters and their structures

- Sunlight-driven reaction<smiles>CC(C)(C)C(=O)ON1C(=O)c2ccccc2C1=O</smiles>

$1 \mathrm{a}(1.5 \mathrm{eq})$<smiles>Sc1ccc(Cl)cc1</smiles>

$\mathbf{2}(0.1 \mathrm{mmol}, 1.0 \mathrm{eq})$

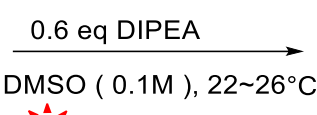

旅 Sunlight, 1 4h<smiles>CC(C)(C)Sc1ccc(Cl)cc1</smiles>

27(up to $87 \%$ )

Table S2. Yields under different sunlight irradiation time.

\begin{tabular}{cc}
\hline Sunlight Irradiation Time & Yield $^{a}$ \\
\hline $10: 00-11: 00(1 \mathrm{~h})$ & $60 \%$ \\
$10: 00-12: 00(2 \mathrm{~h})$ & $87 \%$ \\
$10: 00-13: 00(3 \mathrm{~h})$ & $75 \%$ \\
$10: 00-14: 00(4 \mathrm{~h})$ & $65 \%$ \\
\hline
\end{tabular}

${ }^{a}{ }^{1} \mathrm{H}$ NMR analysis with 1,3,5-trimethoxybenzene as an internal standard. 


\section{Copies for NMR spectra of related compounds}

${ }^{1} \mathrm{H}$ NMR spectrum of Cyclohexyl (4-fluorophenyl) sulfane (3) (500 MHz, $\mathrm{CDCl}_{3}$ ):

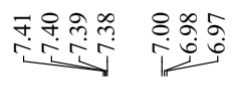

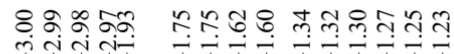

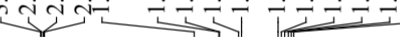
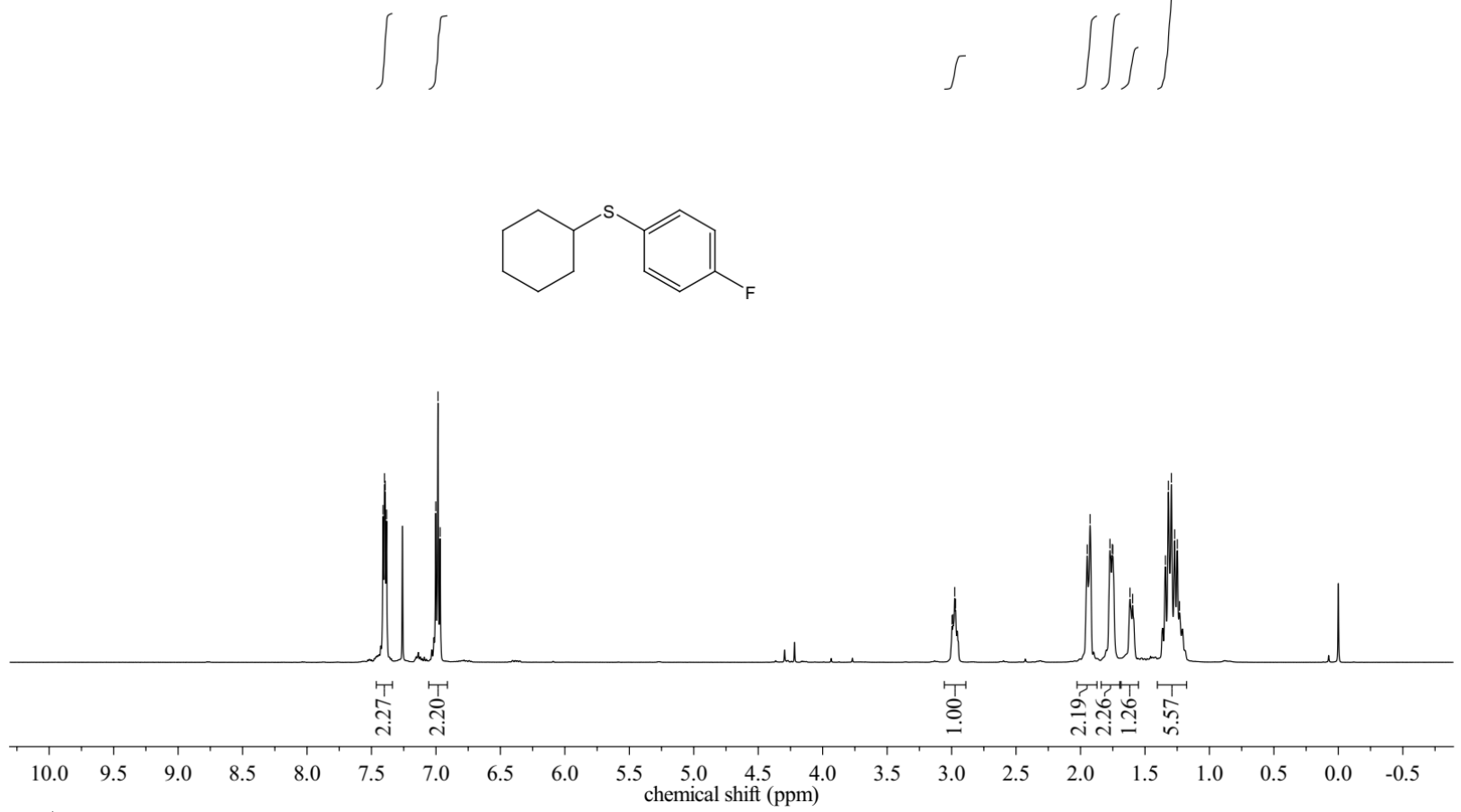

${ }^{13} \mathrm{C}\left\{{ }^{1} \mathrm{H}\right\}$ NMR spectrum of Cyclohexyl (4-fluorophenyl) sulfane (3) (100 MHz, $\left.\mathrm{CDCl}_{3}\right)$ :

$$
\text { ஸீ: }
$$
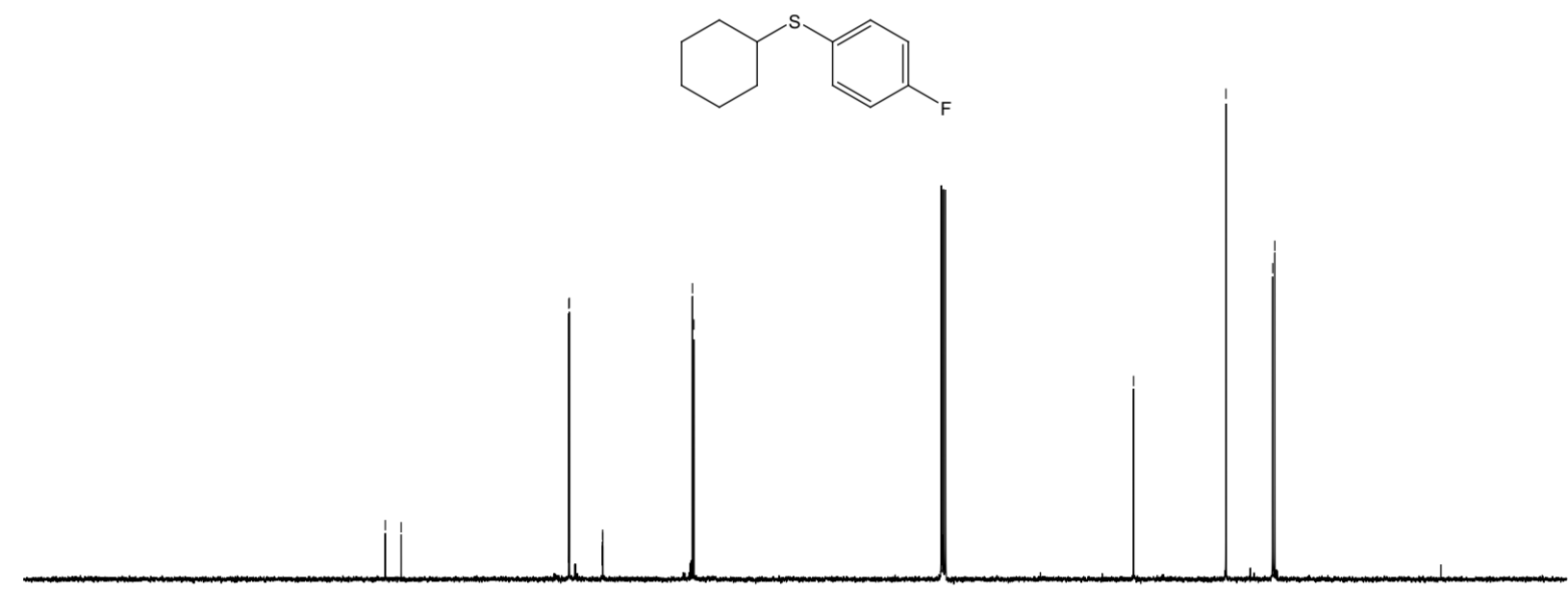

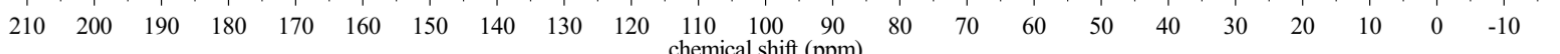


${ }^{19} \mathrm{~F}$ NMR spectrum of Cyclohexyl (4-fluorophenyl) sulfane (3) (375 MHz, $\mathrm{CDCl}_{3}$ ):

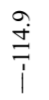<smiles>Fc1ccc(SC2CCCCC2)cc1</smiles>

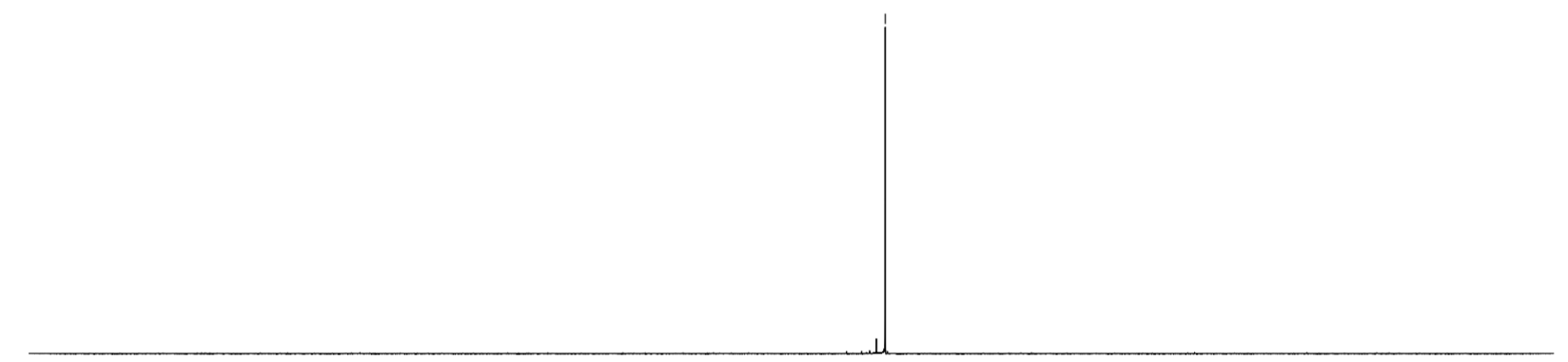

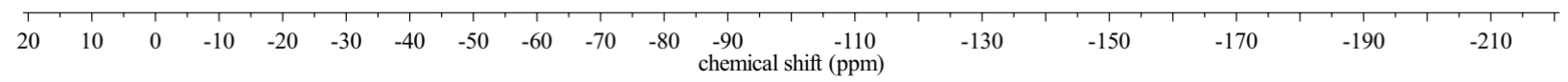

${ }^{1} \mathrm{H}$ NMR spectrum of (4-Chlorophenyl) (cyclohexyl) sulfane (4) (500 MHz, $\mathrm{CDCl}_{3}$ ):

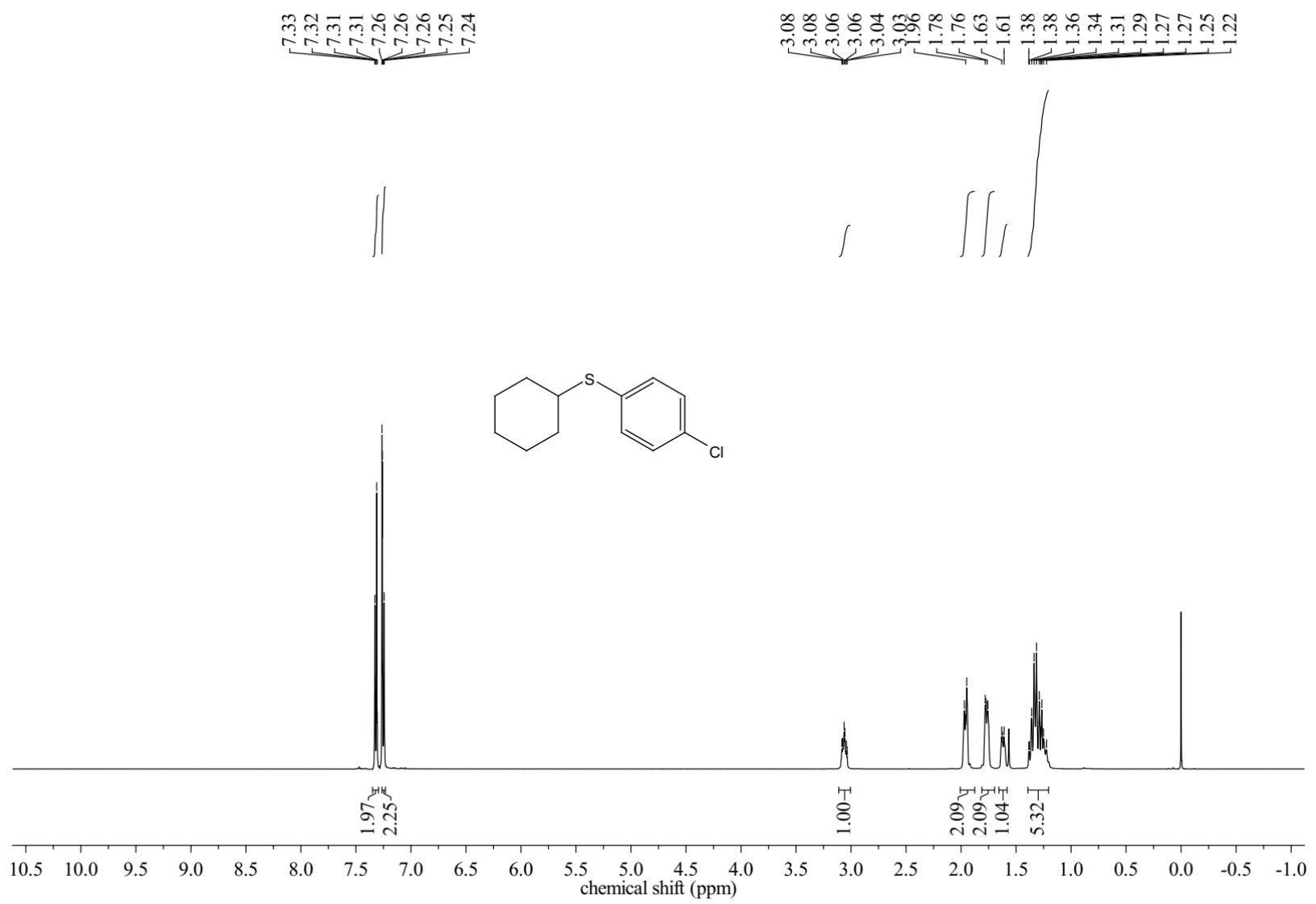


${ }^{13} \mathrm{C}\left\{{ }^{1} \mathrm{H}\right\}$ NMR spectrum of (4-Chlorophenyl) (cyclohexyl) sulfane (4) (125 MHz, $\mathrm{CDCl}_{3}$ ):
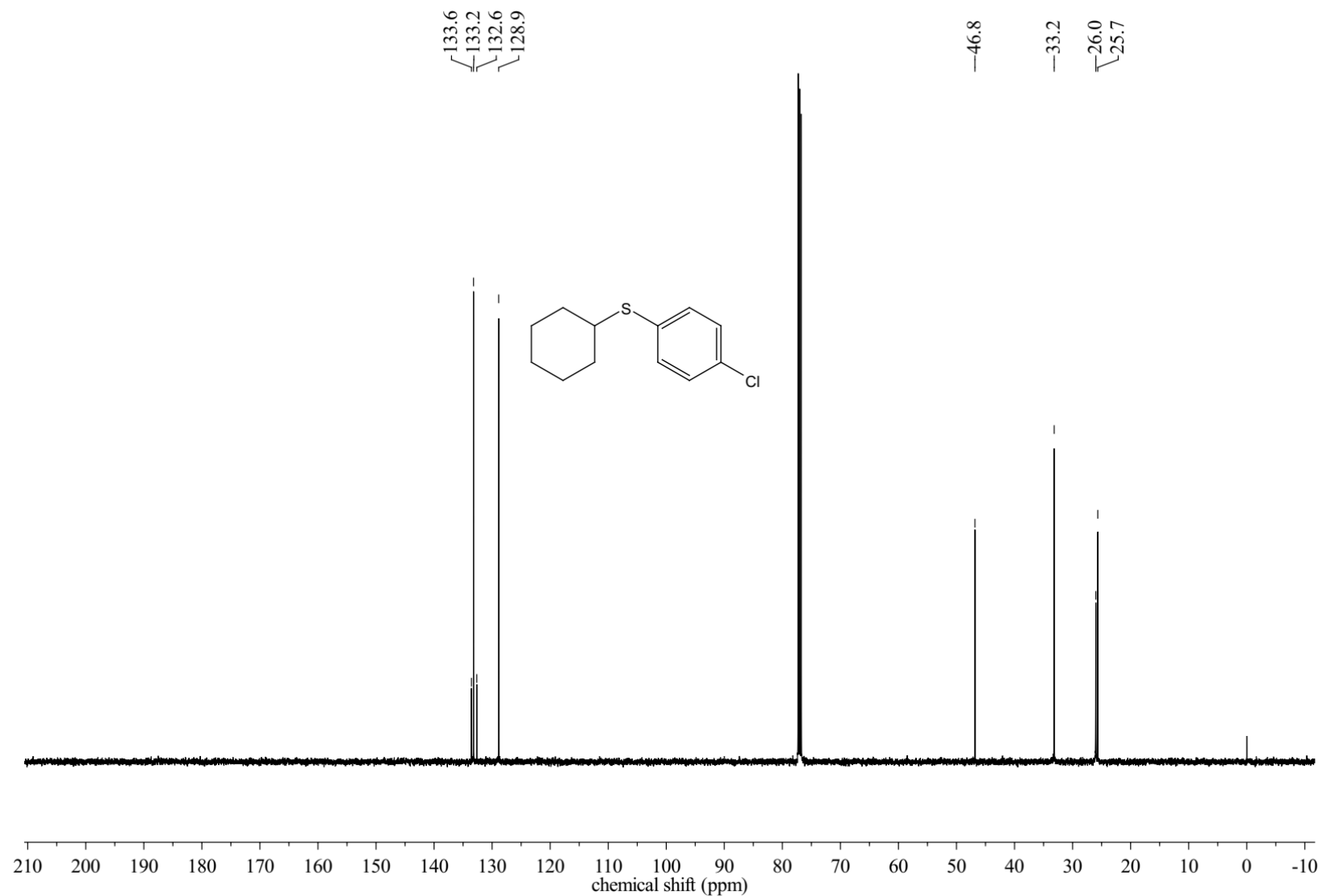

${ }^{1} \mathrm{H}$ NMR spectrum of (4-Bromophenyl) (cyclohexyl) sulfane (5) $\left(500 \mathrm{MHz}, \mathrm{CDCl}_{3}\right.$ ):

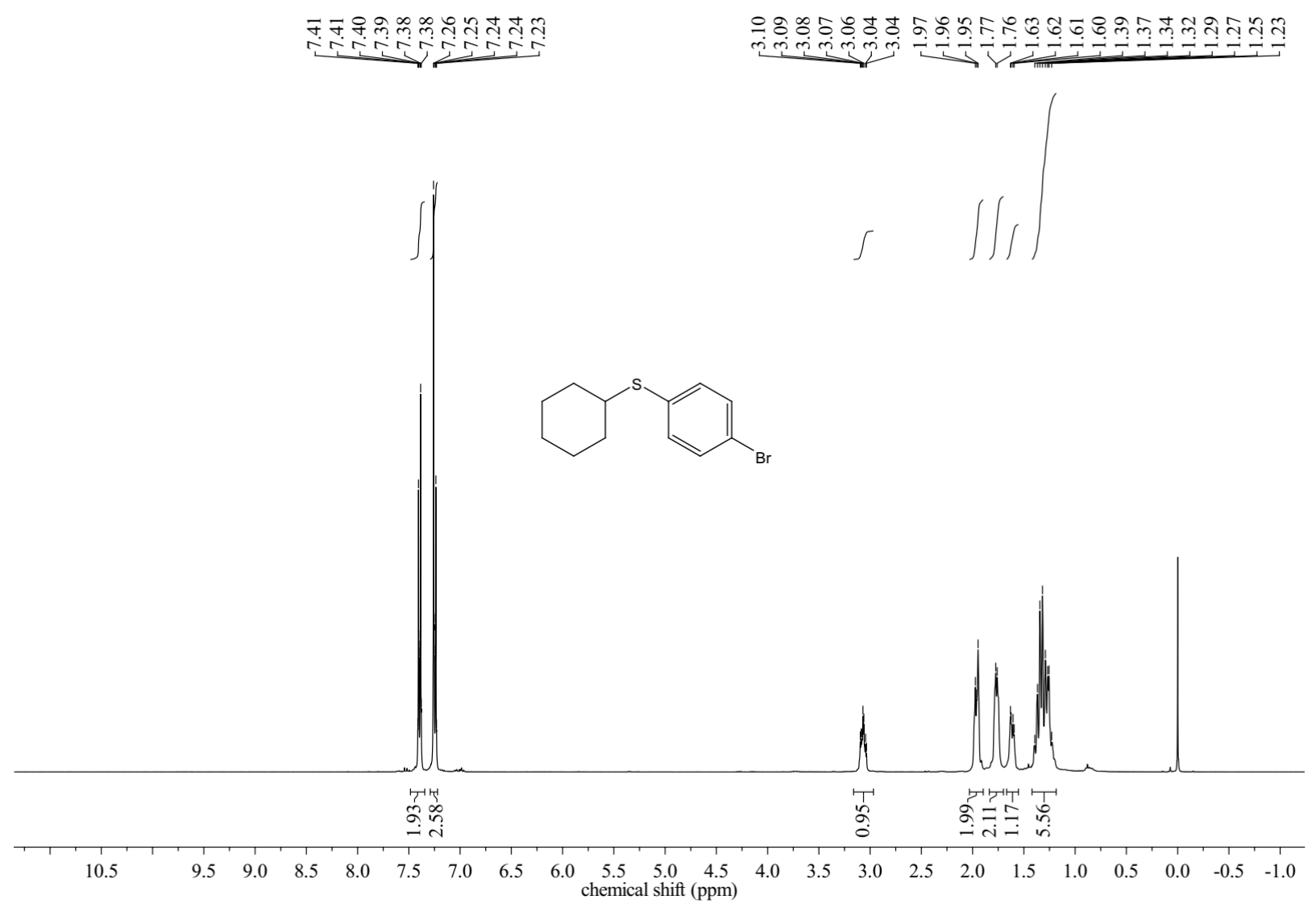


${ }^{13} \mathrm{C}\left\{{ }^{1} \mathrm{H}\right\}$ NMR spectrum of (4-Bromophenyl) (cyclohexyl) sulfane (5) $\left(125 \mathrm{MHz}, \mathrm{CDCl}_{3}\right)$ :

芶芦芦

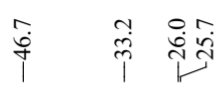
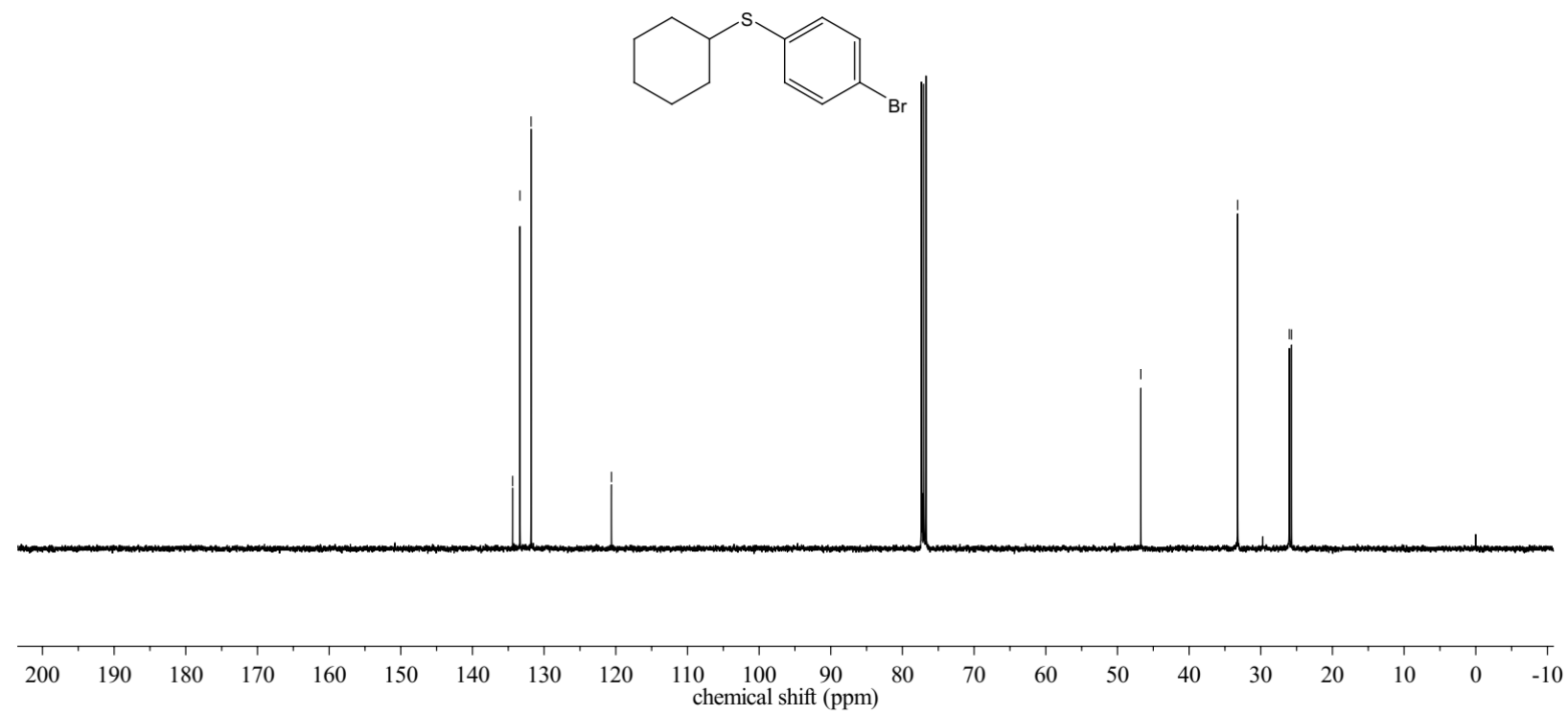

${ }^{1} \mathrm{H}$ NMR spectrum of Cyclohexyl (phenyl) sulfane (6) (500 MHz, $\mathrm{CDCl}_{3}$ ):

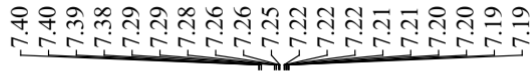

$$
\text { Ili }
$$

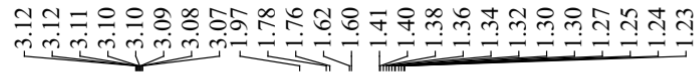

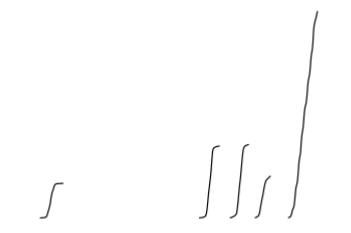

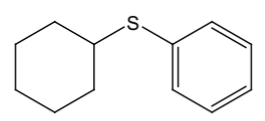

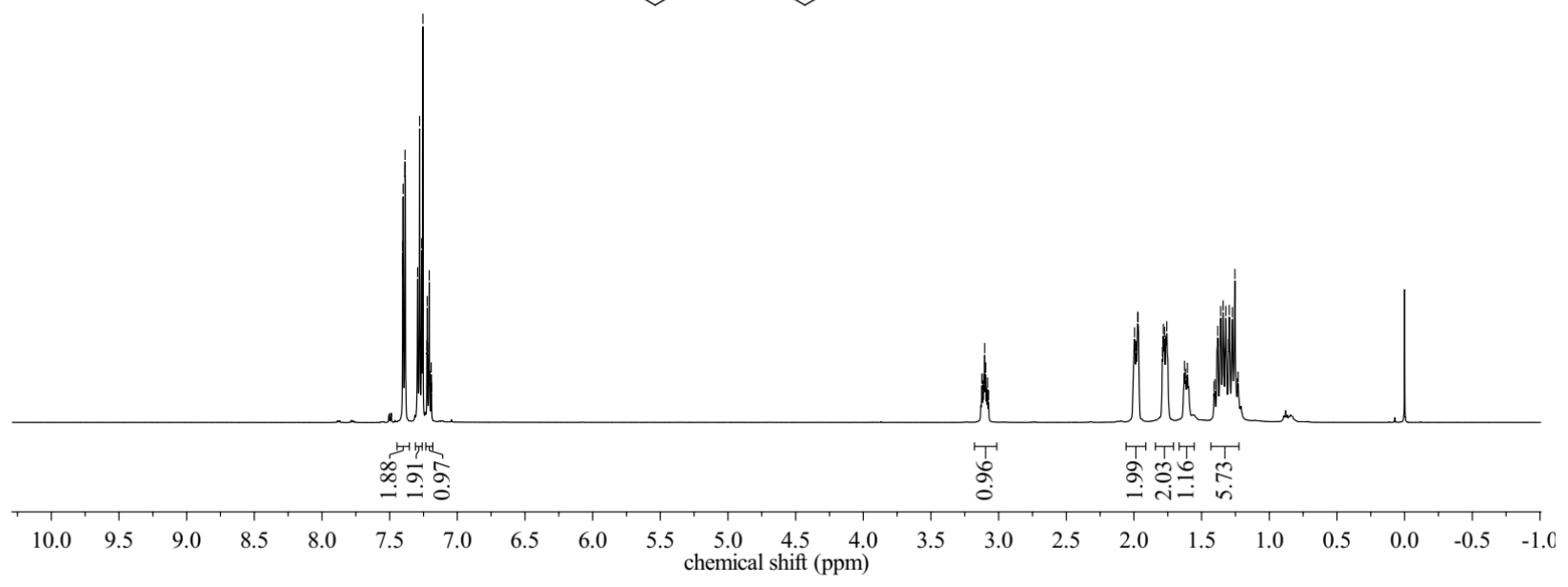

S13 
${ }^{13} \mathrm{C}\left\{{ }^{1} \mathrm{H}\right\}$ NMR spectrum of Cyclohexyl (phenyl) sulfane (6) (125 MHz, $\left.\mathrm{CDCl}_{3}\right)$ :

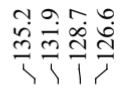

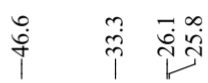
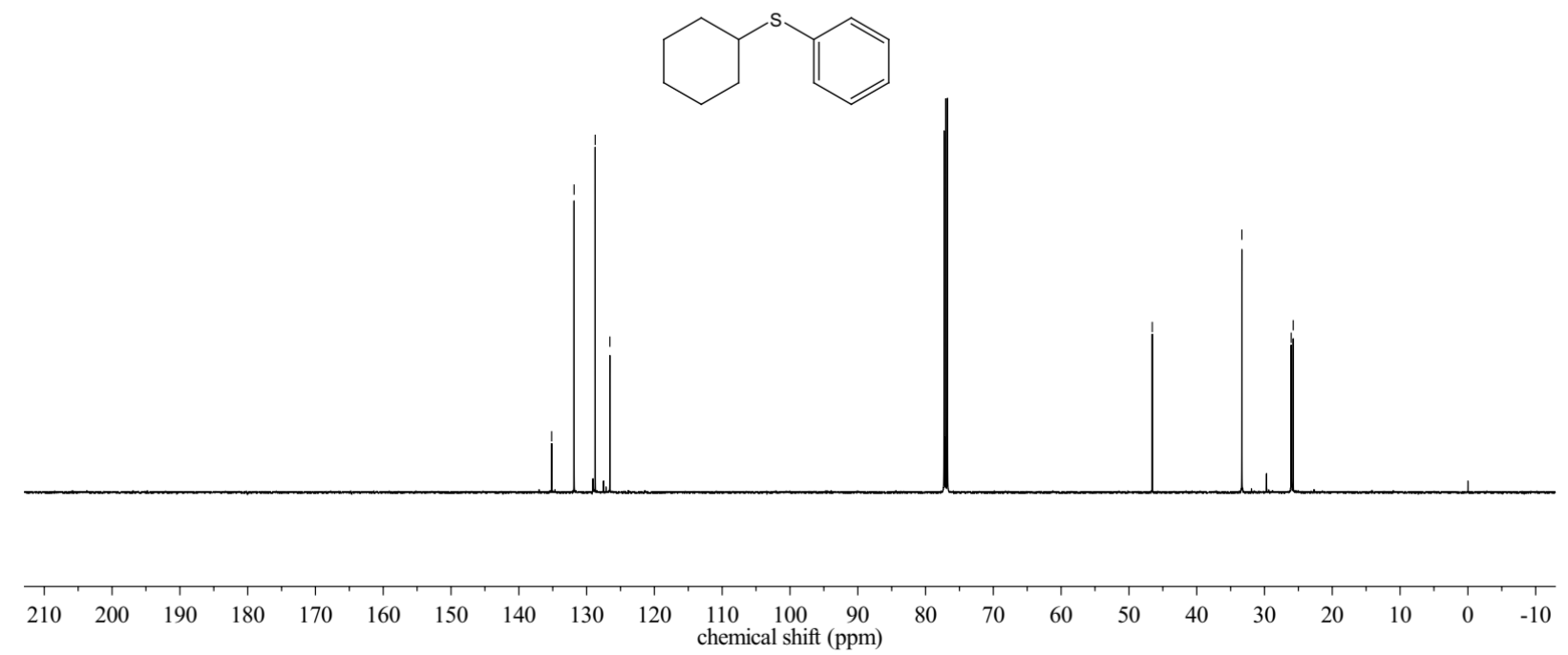

${ }^{1} \mathrm{H}$ NMR spectrum of Cyclohexyl ( $p$-tolyl) sulfane (7) (500 MHz, $\left.\mathrm{CDCl}_{3}\right)$ :

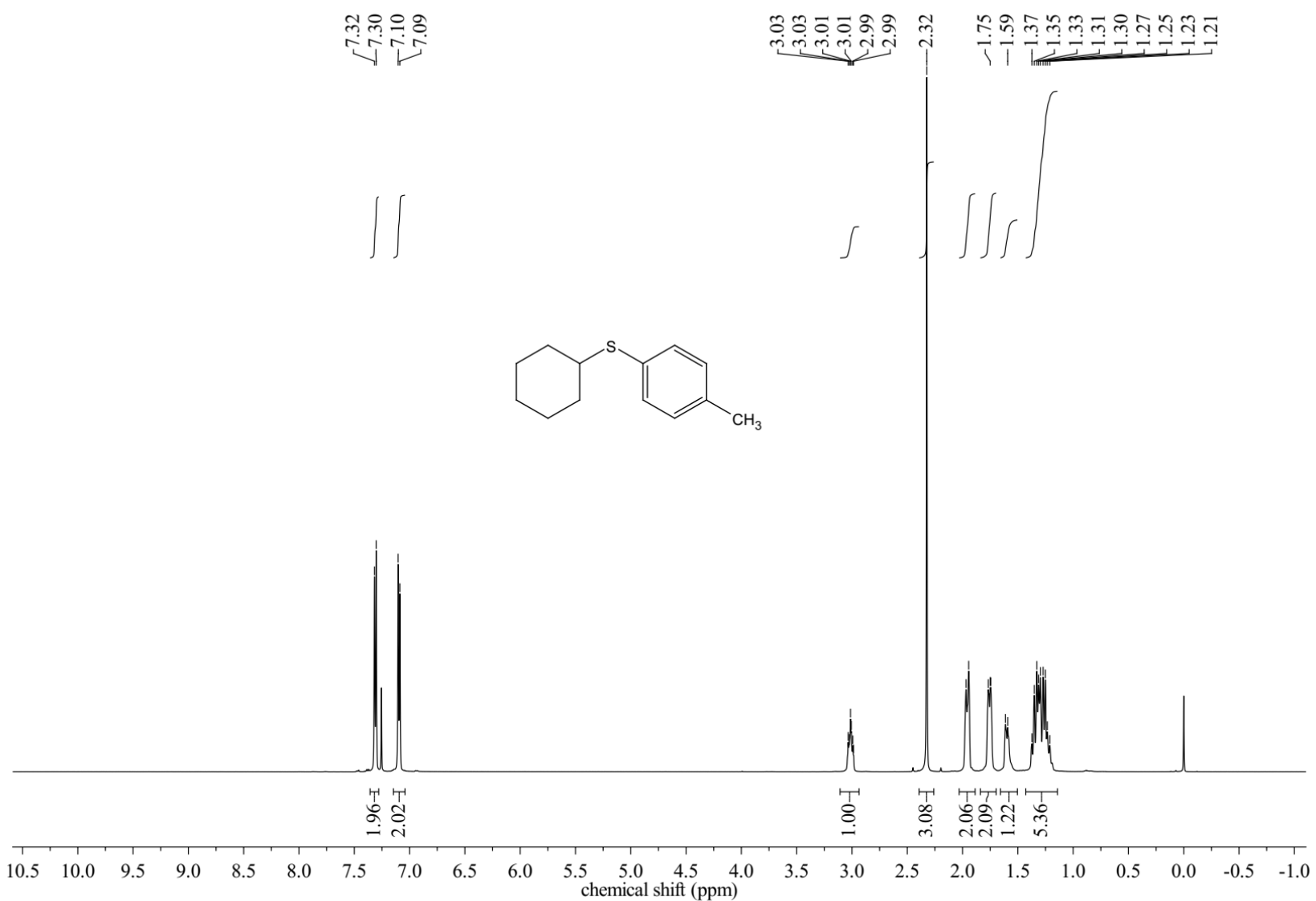


${ }^{13} \mathrm{C}\left\{{ }^{1} \mathrm{H}\right\}$ NMR spectrum of Cyclohexyl (p-tolyl) sulfane (7) (125 MHz, $\mathrm{CDCl}_{3}$ ):
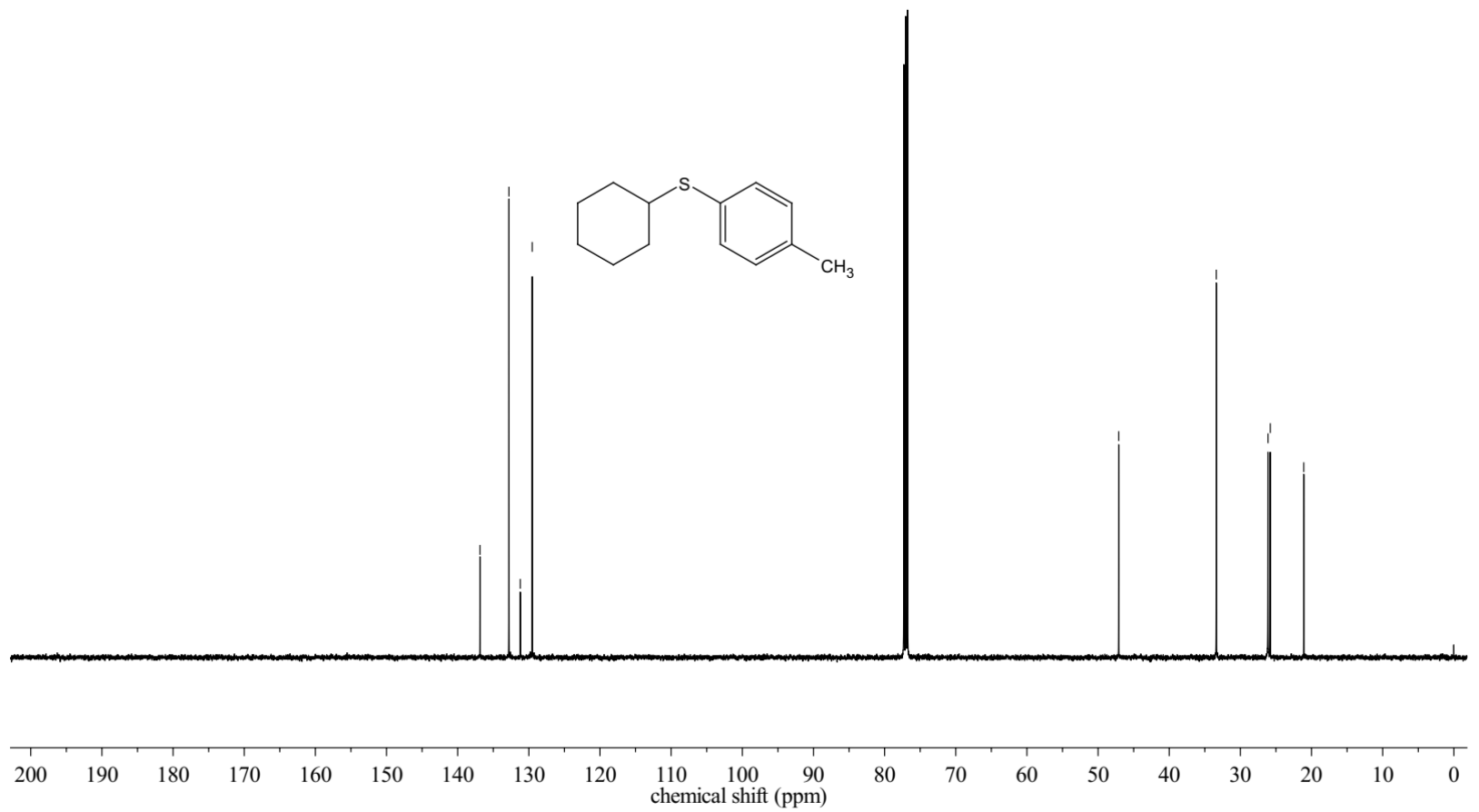

${ }^{1} \mathrm{H}$ NMR spectrum of Cyclohexyl (4-methoxyphenyl) sulfane (8) (500 MHz, $\mathrm{CDCl}_{3}$ ):

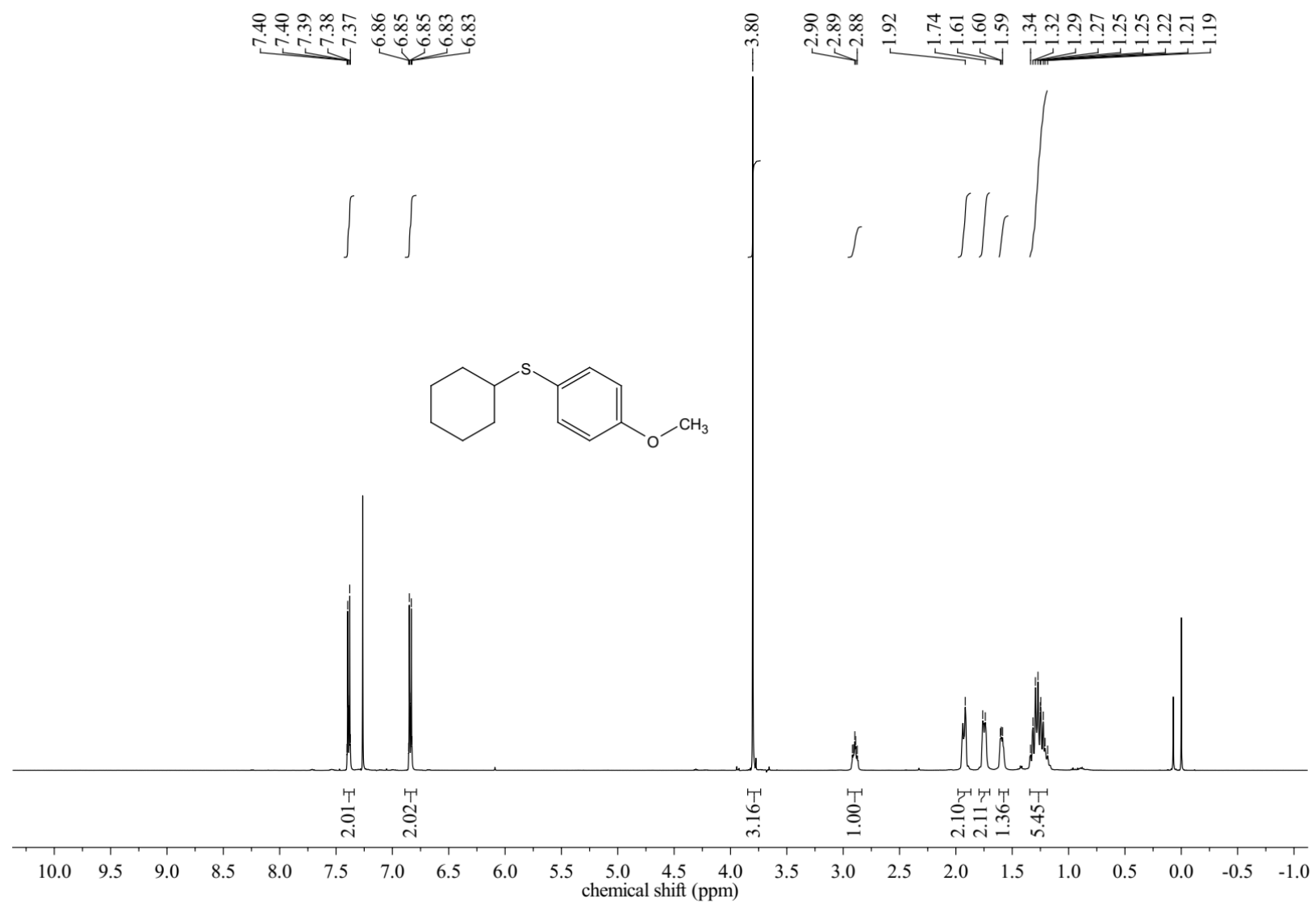


${ }^{13} \mathrm{C}\left\{{ }^{1} \mathrm{H}\right\}$ NMR spectrum of Cyclohexyl (4-methoxyphenyl) sulfane (8) $\left(125 \mathrm{MHz}, \mathrm{CDCl}_{3}\right)$ :
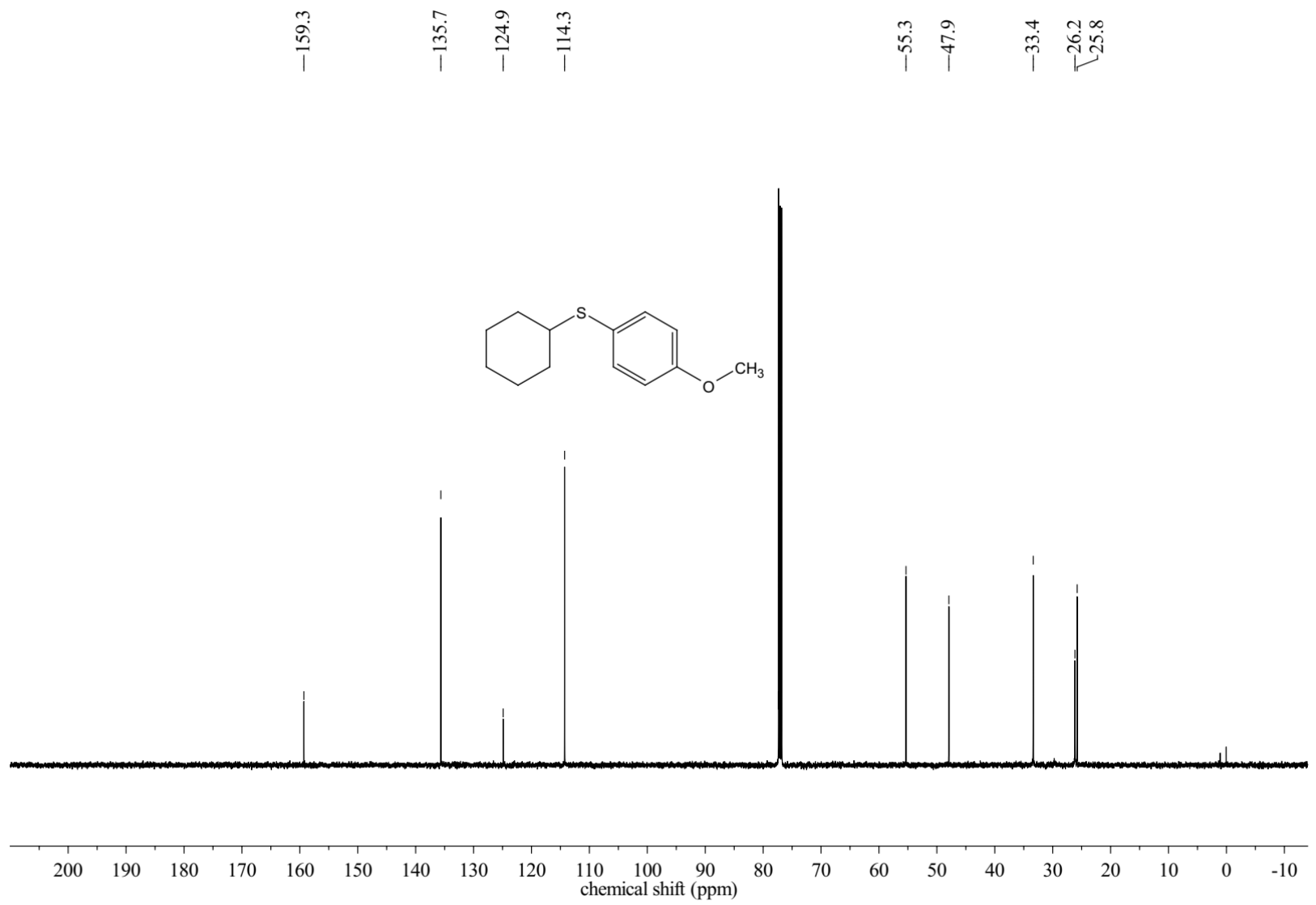

${ }^{1} \mathrm{H}$ NMR spectrum of 2-(Cyclohexylthio) benzo[d] thiazole (9) (500 MHz, $\left.\mathrm{CDCl}_{3}\right)$ :
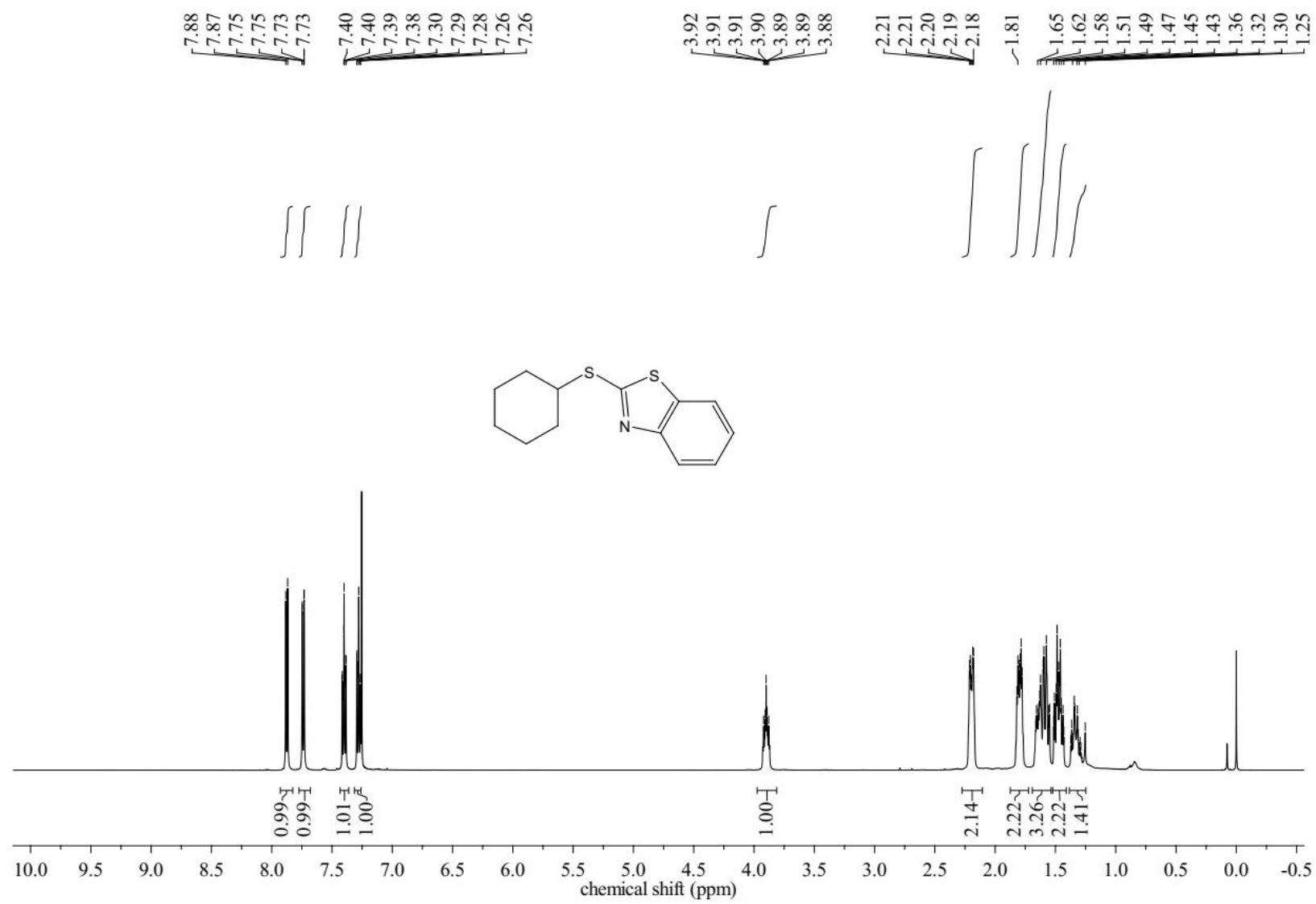
${ }^{13} \mathrm{C}\left\{{ }^{1} \mathrm{H}\right\}$ NMR spectrum of 2-(Cyclohexylthio) benzo $[d]$ thiazole (9) $\left(125 \mathrm{MHz}, \mathrm{CDCl}_{3}\right)$ :

$$
\text { 苋 }
$$
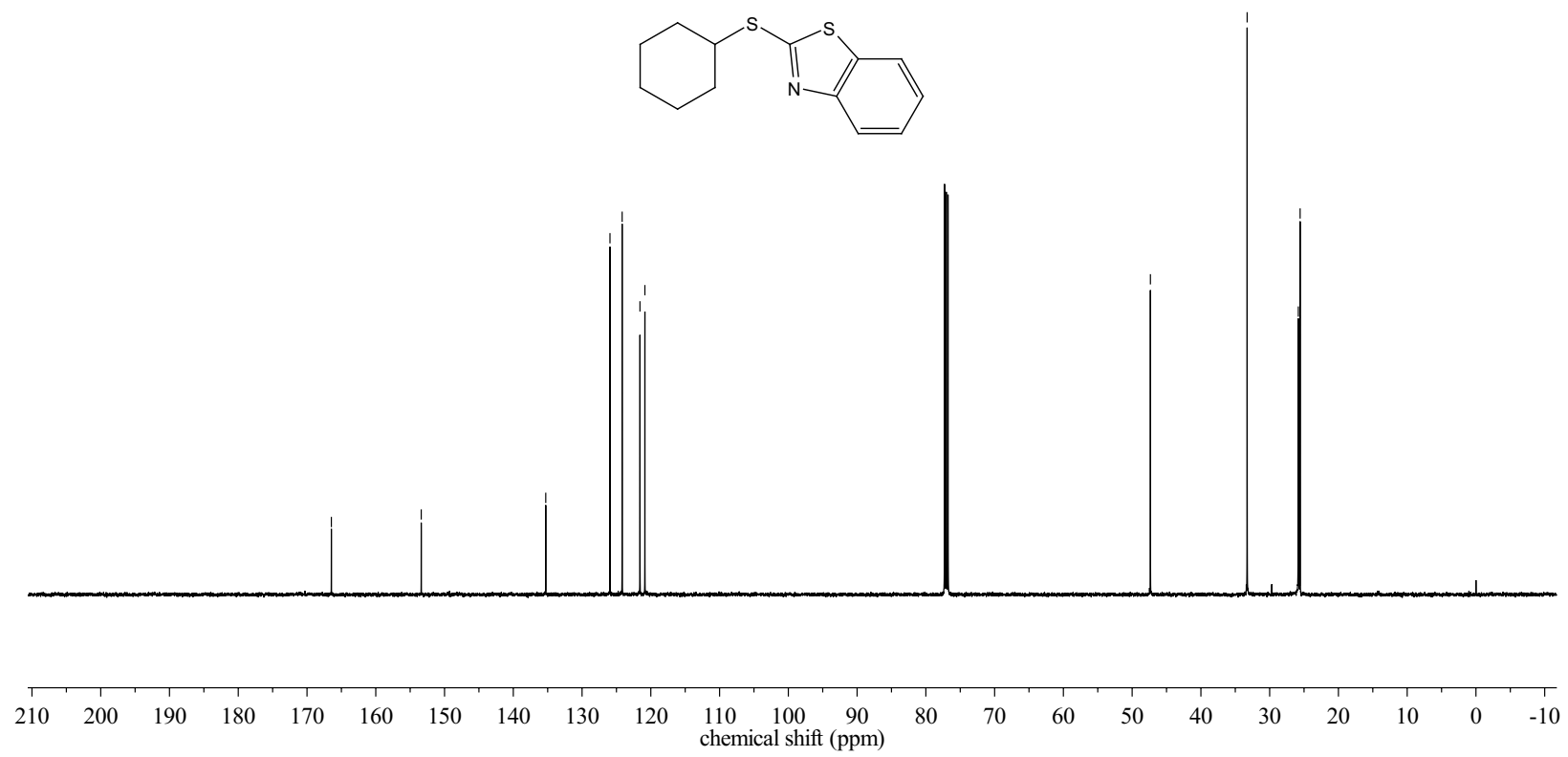

${ }^{1} \mathrm{H}$ NMR spectrum of 2-(Cyclohexylthio) pyridine (10) $\left(500 \mathrm{MHz}, \mathrm{CDCl}_{3}\right)\left(125 \mathrm{MHz}, \mathrm{CDCl}_{3}\right)$ :

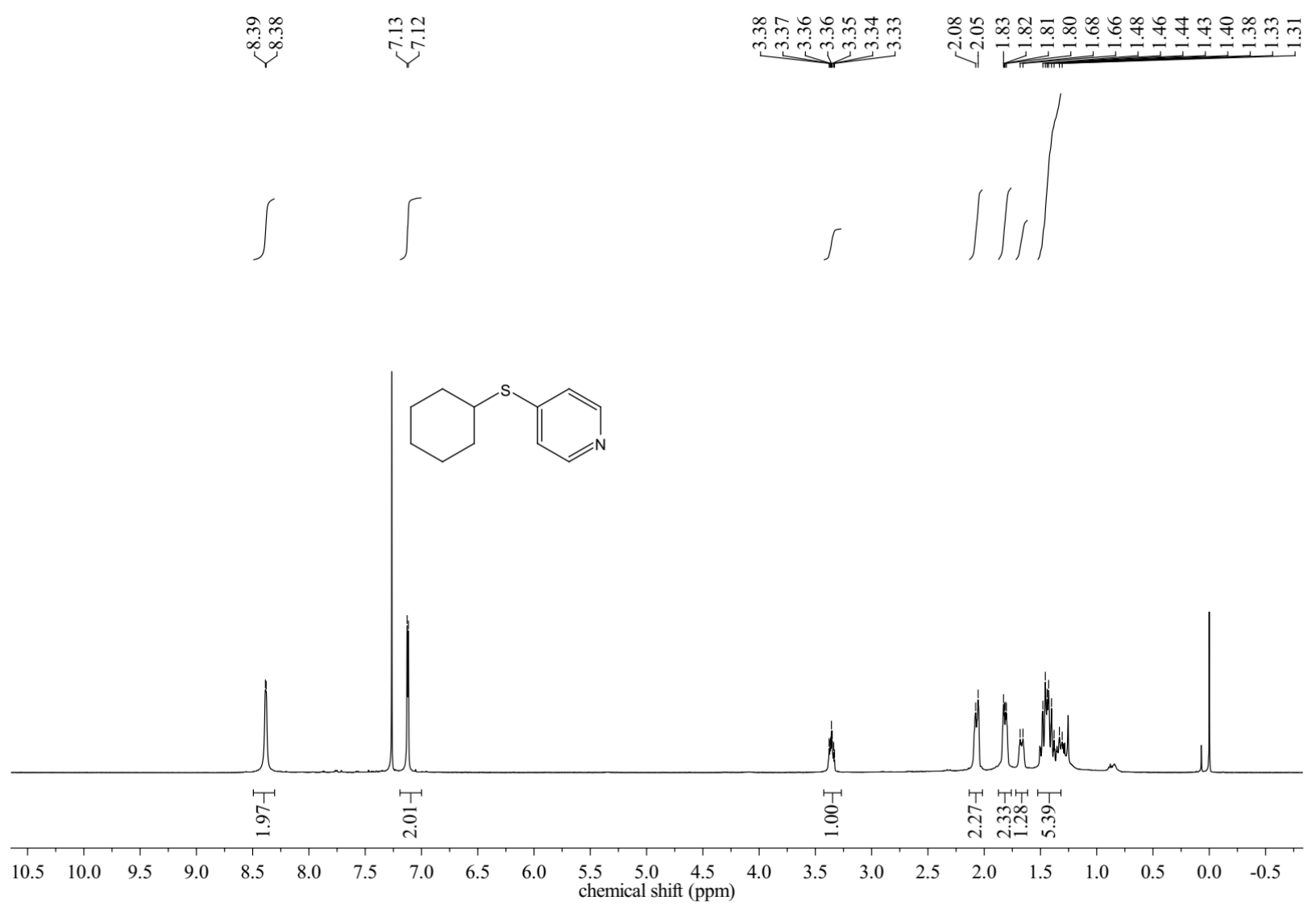


${ }^{13} \mathrm{C}\left\{{ }^{1} \mathrm{H}\right\}$ NMR spectrum of 2-(Cyclohexylthio) pyridine (10) (125 MHz, $\left.\mathrm{CDCl}_{3}\right)$ :

产字 $\stackrel{\infty}{i}$

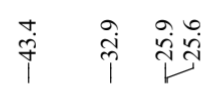
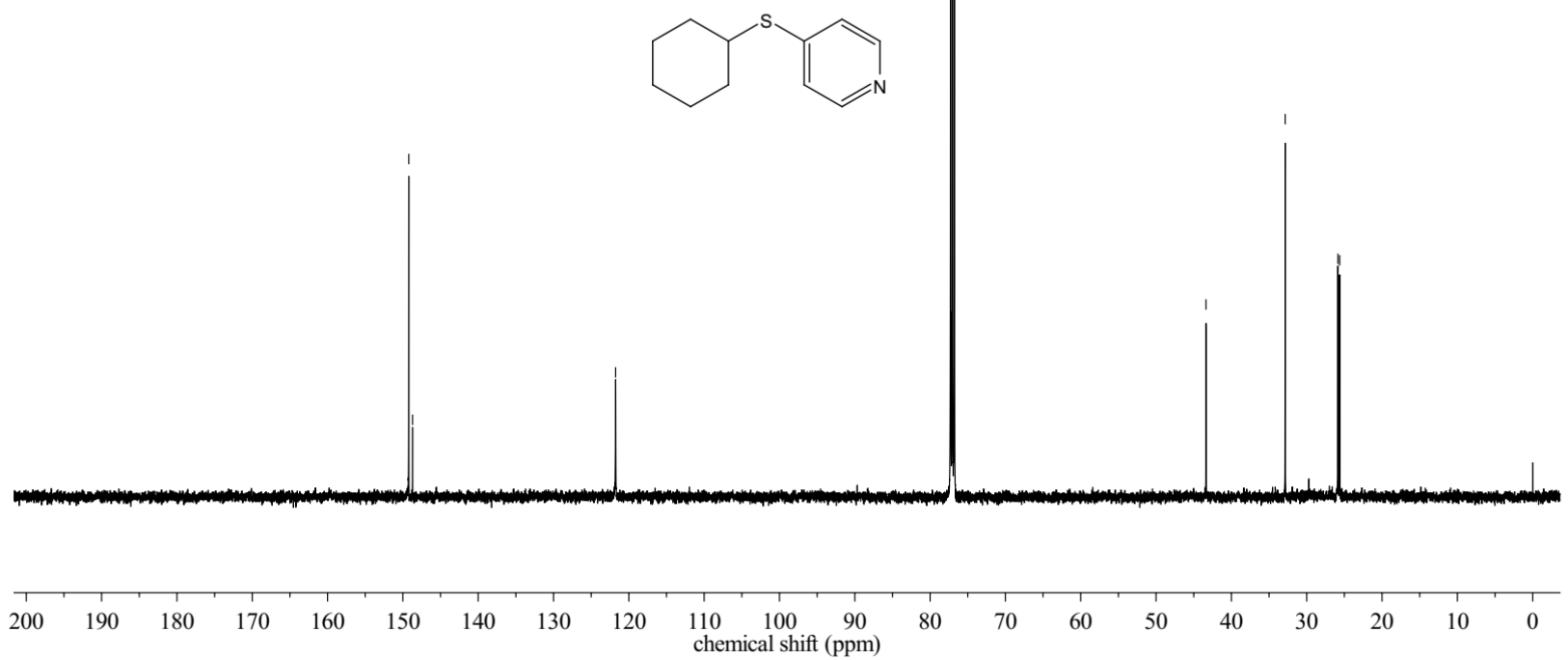

${ }^{1} \mathrm{H}$ NMR spectrum of Cyclohexyl (naphthalen-2-yl) sulfane (11) (500 MHz, $\left.\mathrm{CDCl}_{3}\right)$ :

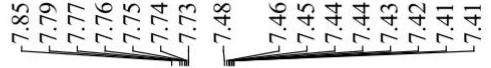

$$
\iint
$$

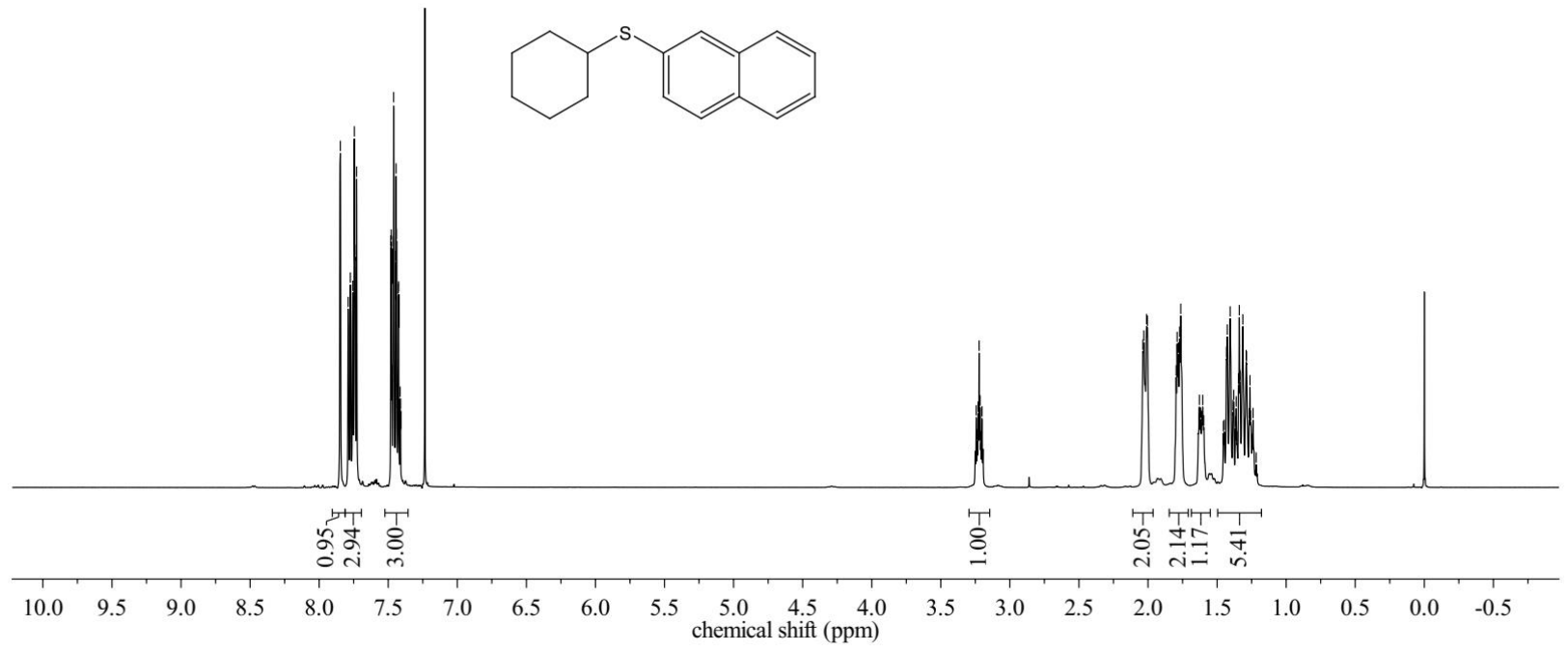

$\mathrm{S} 18$

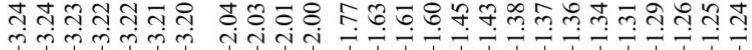


${ }^{13} \mathrm{C}\left\{{ }^{1} \mathrm{H}\right\}$ NMR spectrum of Cyclohexyl (naphthalen-2-yl) sulfane (11) $\left(125 \mathrm{MHz}, \mathrm{CDCl}_{3}\right)$ :

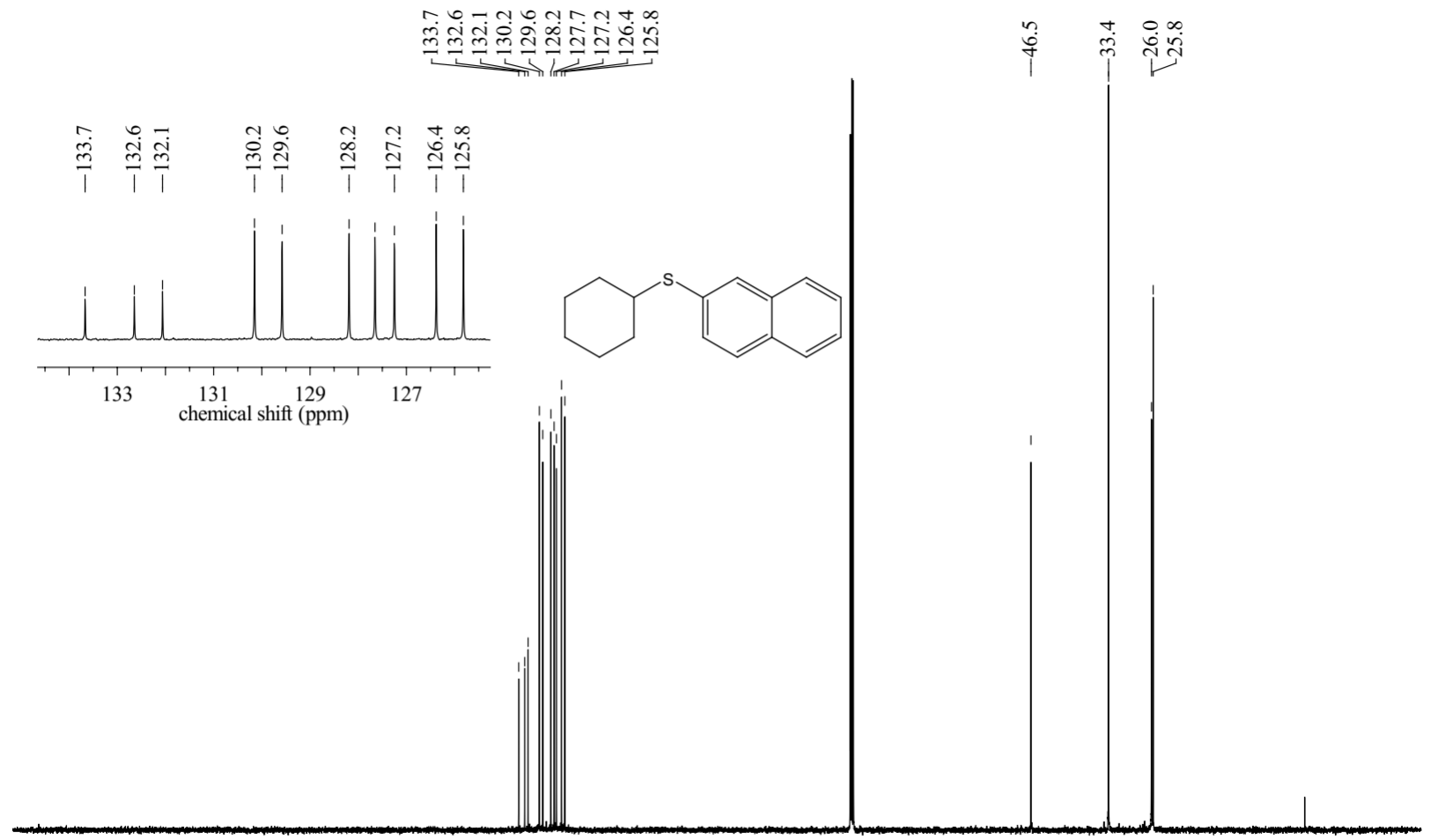

$\begin{array}{llllllllllllllllllllll}210 & 200 & 190 & 180 & 170 & 160 & 150 & 140 & 130 & 120 & \begin{array}{c}110 \\ \text { chemical shift (ppm) }\end{array} & 80 & 70 & 60 & 50 & 40 & 30 & 20 & 10 & 0 & -10\end{array}$

${ }^{1} \mathrm{H}$ NMR spectrum of 4-(Naphthalen-2-ylthio) butan-2-one (12) (500 MHz, $\left.\mathrm{CDCl}_{3}\right)$ :

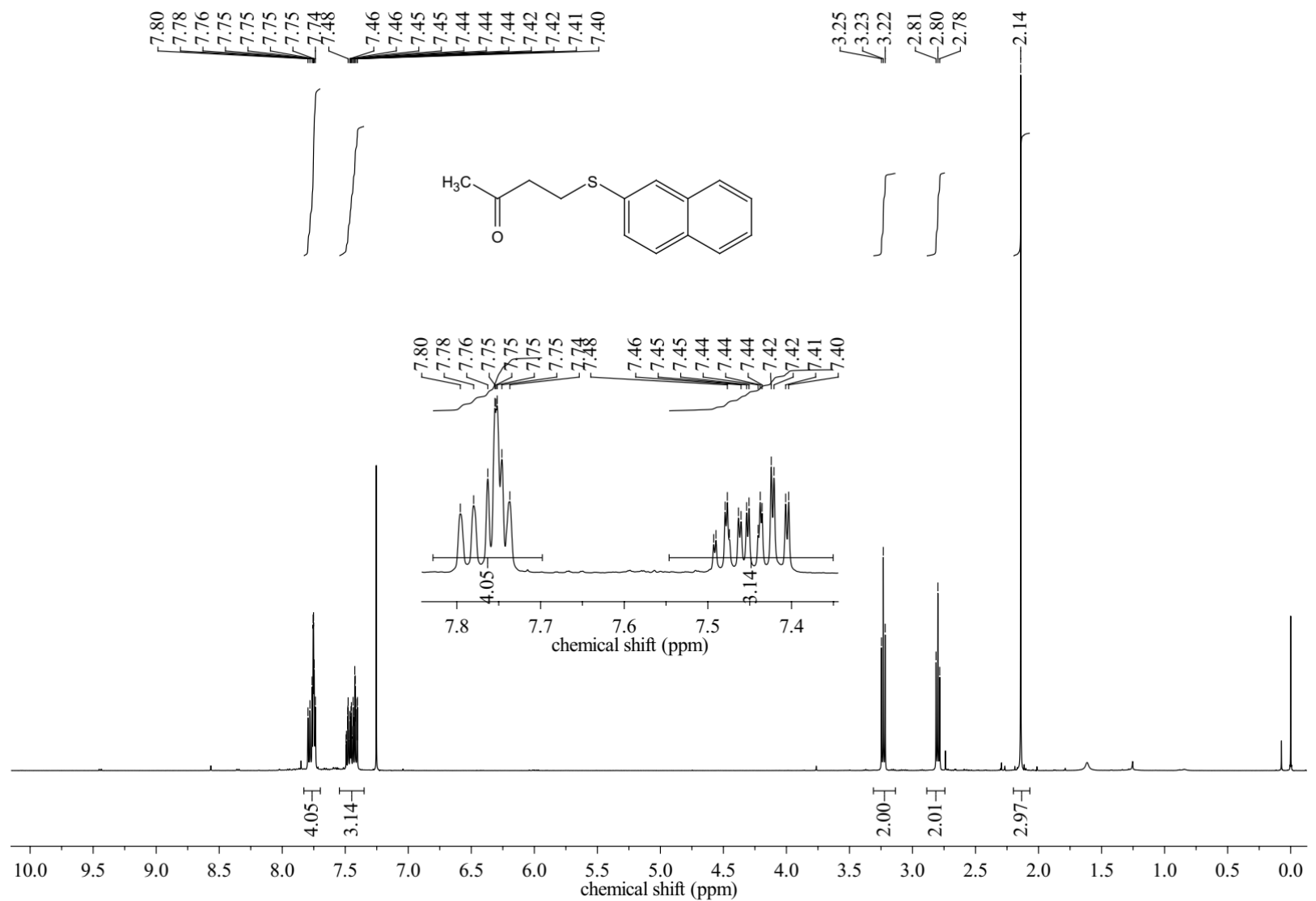


${ }^{13} \mathrm{C}\left\{{ }^{1} \mathrm{H}\right\}$ NMR spectrum of 4-(Naphthalen-2-ylthio) butan-2-one (12) $\left(125 \mathrm{MHz}, \mathrm{CDCl}_{3}\right)$ :

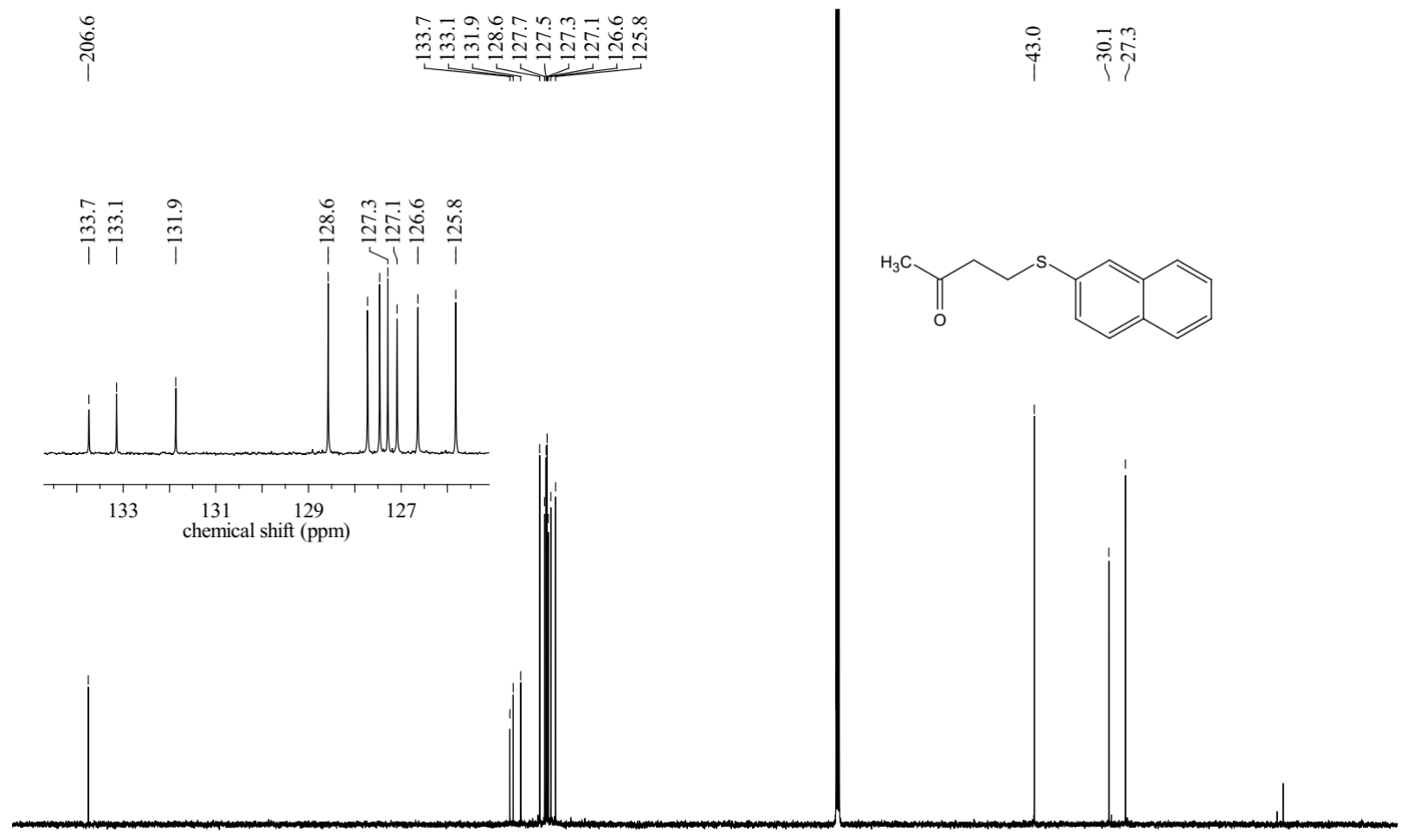

$\begin{array}{lllllllllllllllllllll}210 & 200 & 190 & 180 & 170 & 160 & 150 & 140 & 130 & 120 & \begin{array}{c}110 \\ \text { chemical shift (ppm) }\end{array} & 80 & 70 & 60 & 50 & 40 & 30 & 20 & 10 & 0 & -10\end{array}$

${ }^{1} \mathrm{H}$ NMR spectrum of 4-((4-Fluorophenyl) thio) butan-2-one (13) $\left(500 \mathrm{MHz}, \mathrm{CDCl}_{3}\right)$ :

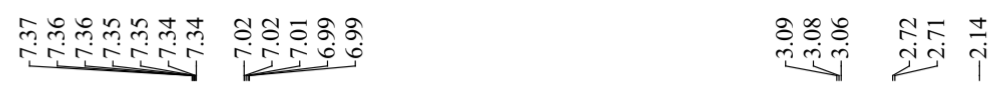
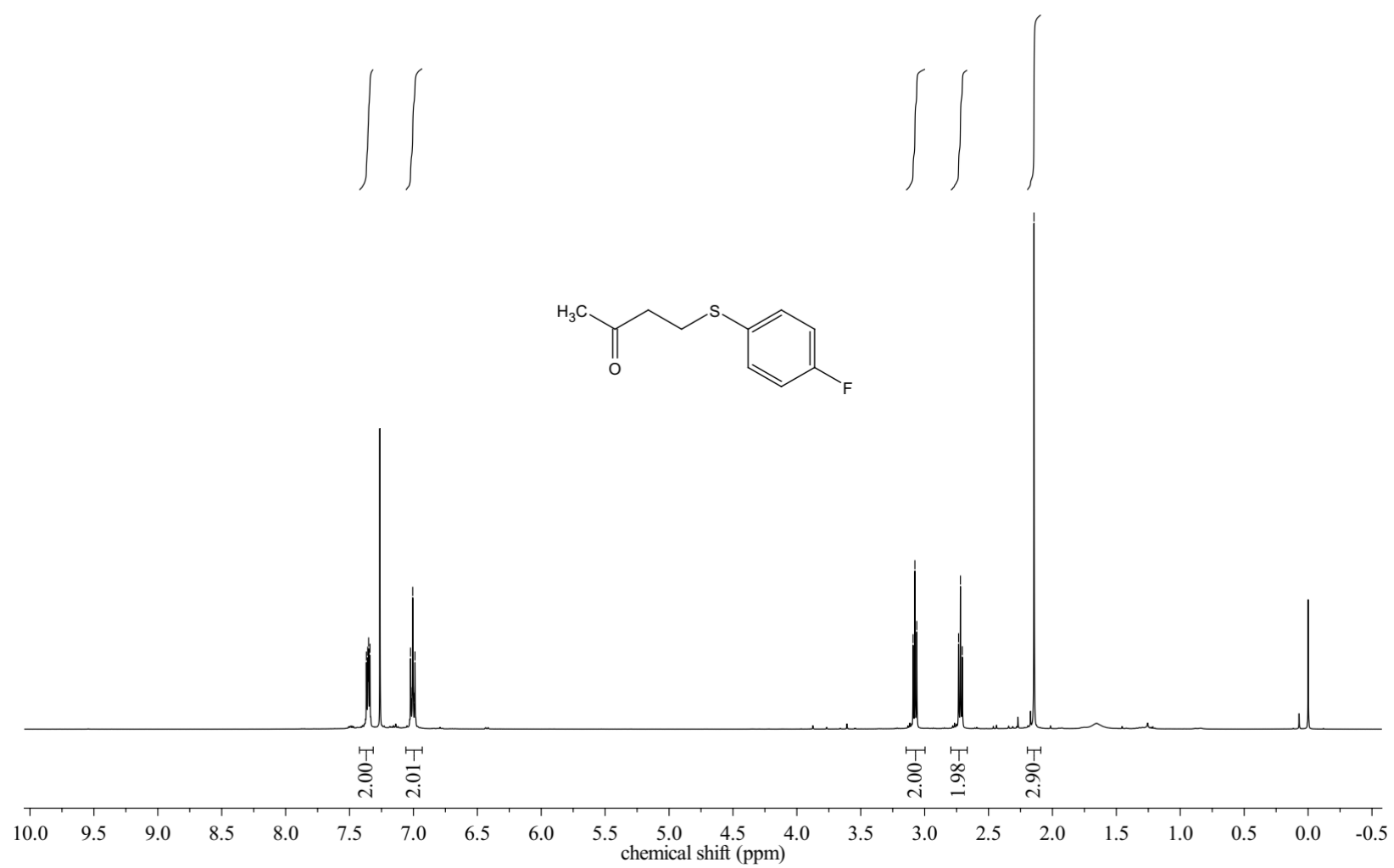
${ }^{13} \mathrm{C}\left\{{ }^{1} \mathrm{H}\right\}$ NMR spectrum of 4-((4-Fluorophenyl) thio) butan-2-one (13) (125 MHz, $\left.\mathrm{CDCl}_{3}\right)$ :

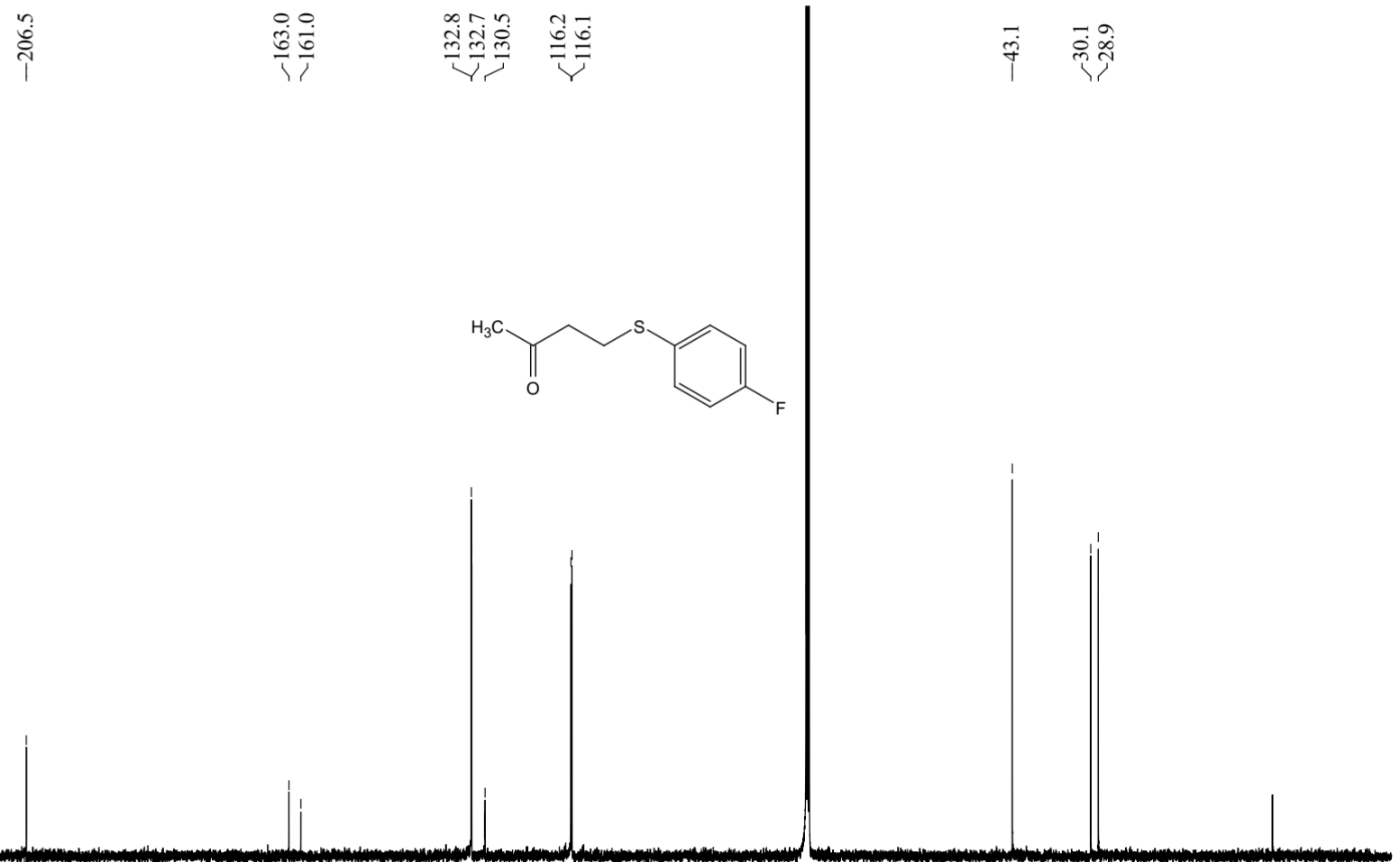

$\begin{array}{lllllllllllllllllllll}210 & 200 & 190 & 180 & 170 & 160 & 150 & 140 & 130 & 120 & \begin{array}{c}110 \\ \text { chemical shift (ppm) }\end{array} & 80 & 70 & 60 & 50 & 40 & 30 & 20 & 10 & 0 & -10\end{array}$

${ }^{19} \mathrm{~F}$ NMR spectrum of 4-((4-Fluorophenyl) thio) butan-2-one (13) $\left(375 \mathrm{MHz}, \mathrm{CDCl}_{3}\right)$ :

$\frac{7}{i}$

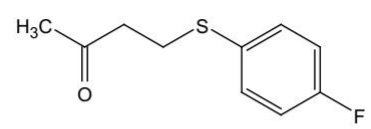

$\begin{array}{lllllllllllllll}-30 & -35 & -40 & -45 & -50 & -55 & -60 & -65 & -70 & -75 & -80 & -85 & -90 & -95 & -100\end{array}$ chemical shift $(\mathrm{ppm})$ 
${ }^{1} \mathrm{H}$ NMR spectrum of 4-((4-Chlorophenyl) thio) butan-2-one (14) (500 MHz, DMSO- $\left.d_{6}\right)$ :

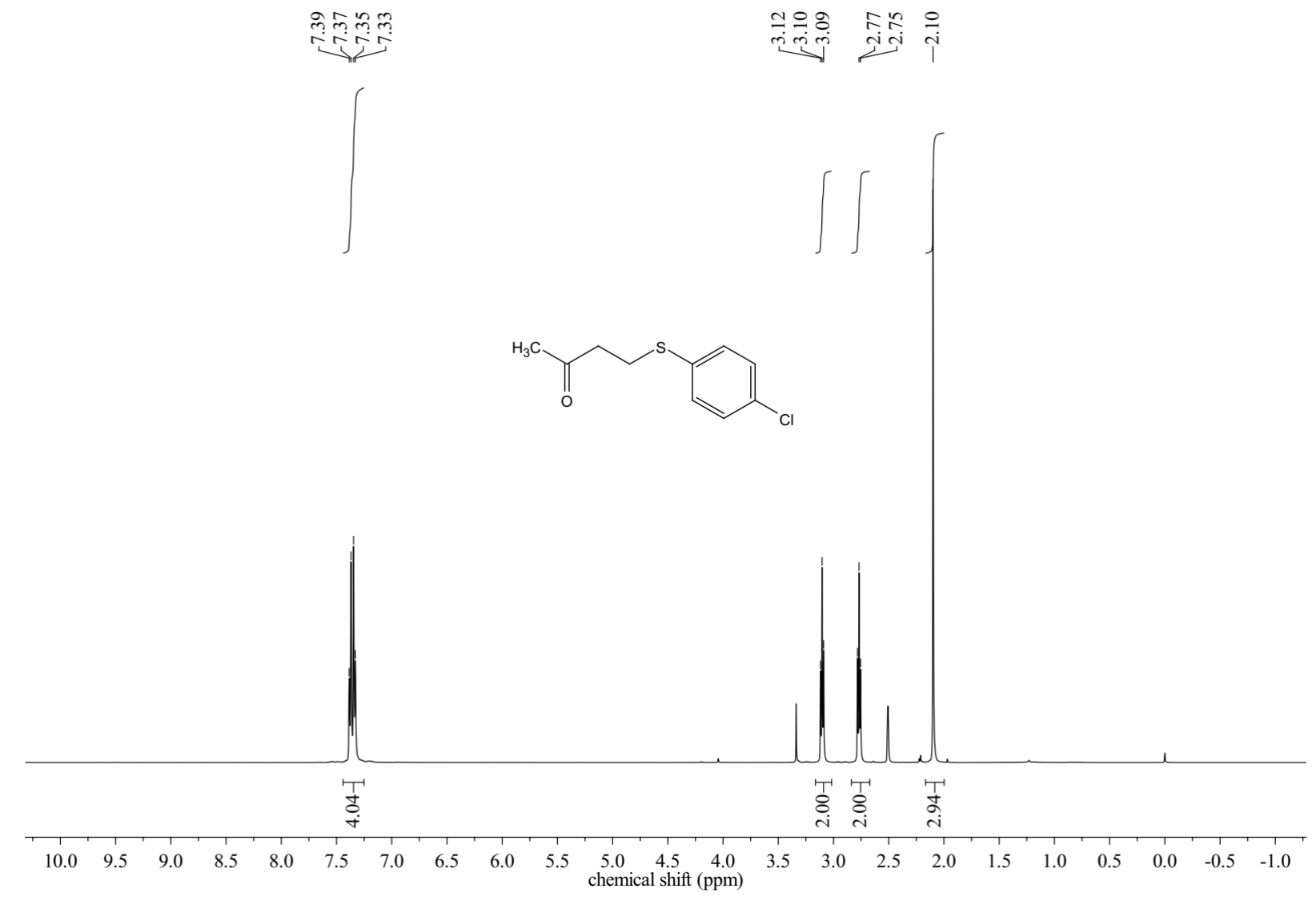

${ }^{13} \mathrm{C}\left\{{ }^{1} \mathrm{H}\right\}$ NMR spectrum of 4-((4-Chlorophenyl) thio) butan-2-one (14) (125 MHz, DMSO- $\left.d_{6}\right)$ :
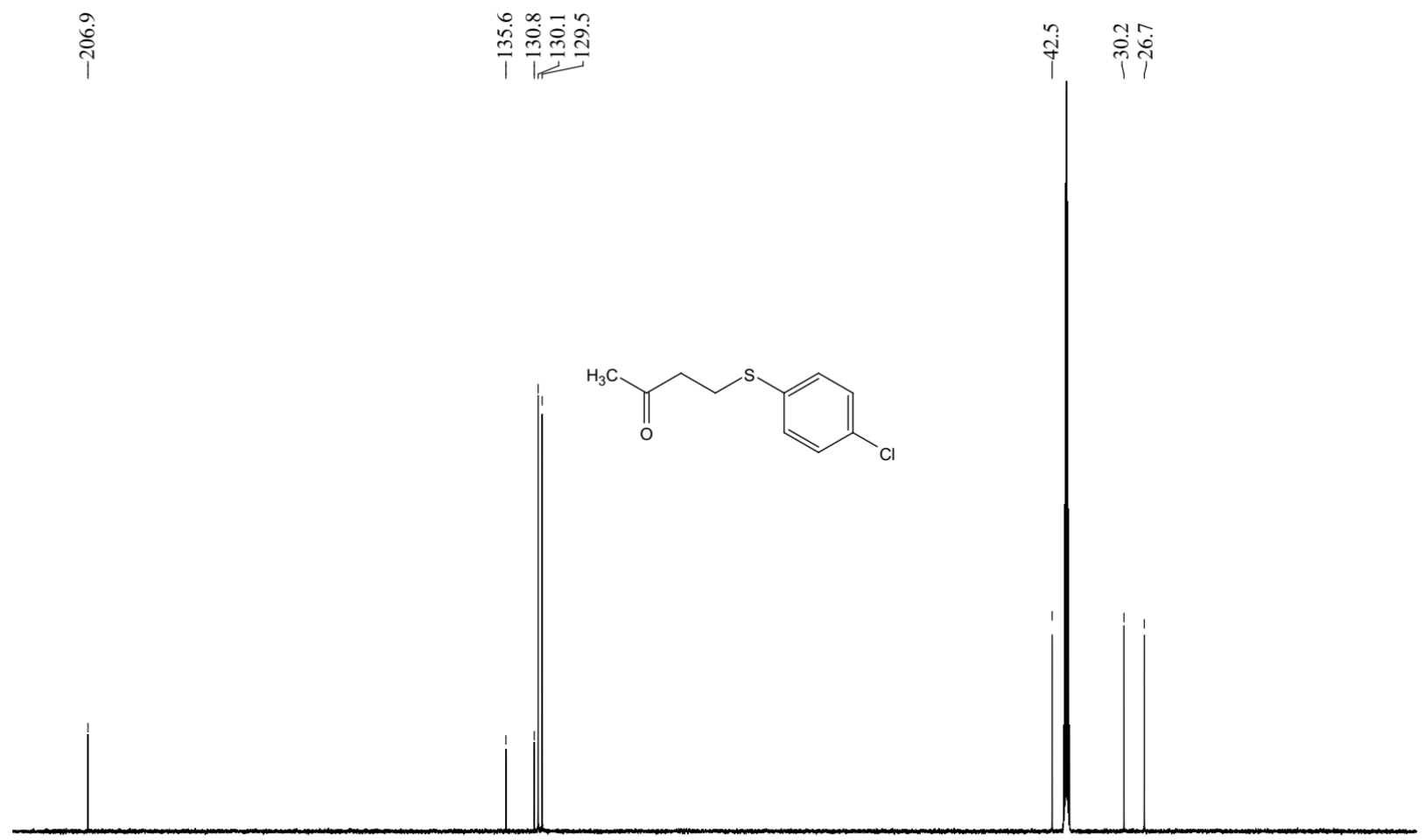

$\begin{array}{lllllllllllllllllllllll}210 & 200 & 190 & 180 & 170 & 160 & 150 & 140 & 130 & 120 & 110 & 100 & 90 & 80 & 70 & 60 & 50 & 40 & 30 & 20 & 10 & 0 & -10\end{array}$ 
${ }^{1} \mathrm{H}$ NMR spectrum of But-3-en-1-yl (4-chlorophenyl) sulfane (15) (500 MHz, $\mathrm{CDCl}_{3}$ ):

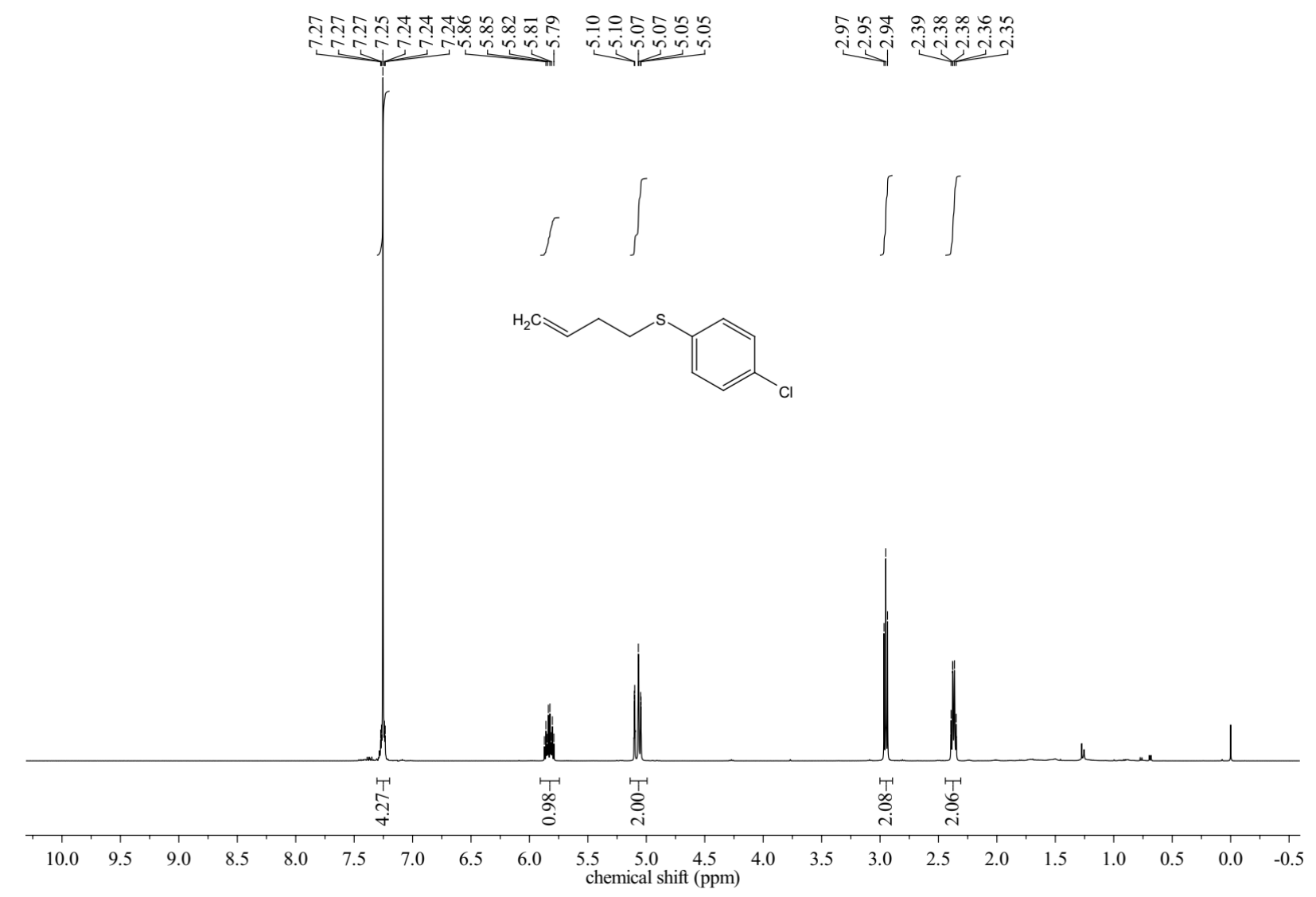

${ }^{13} \mathrm{C}\left\{{ }^{1} \mathrm{H}\right\}$ NMR spectrum of But-3-en-1-yl (4-chlorophenyl) sulfane (15) (125 MHz, $\mathrm{CDCl}_{3}$ ):

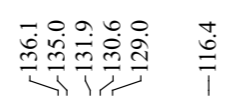

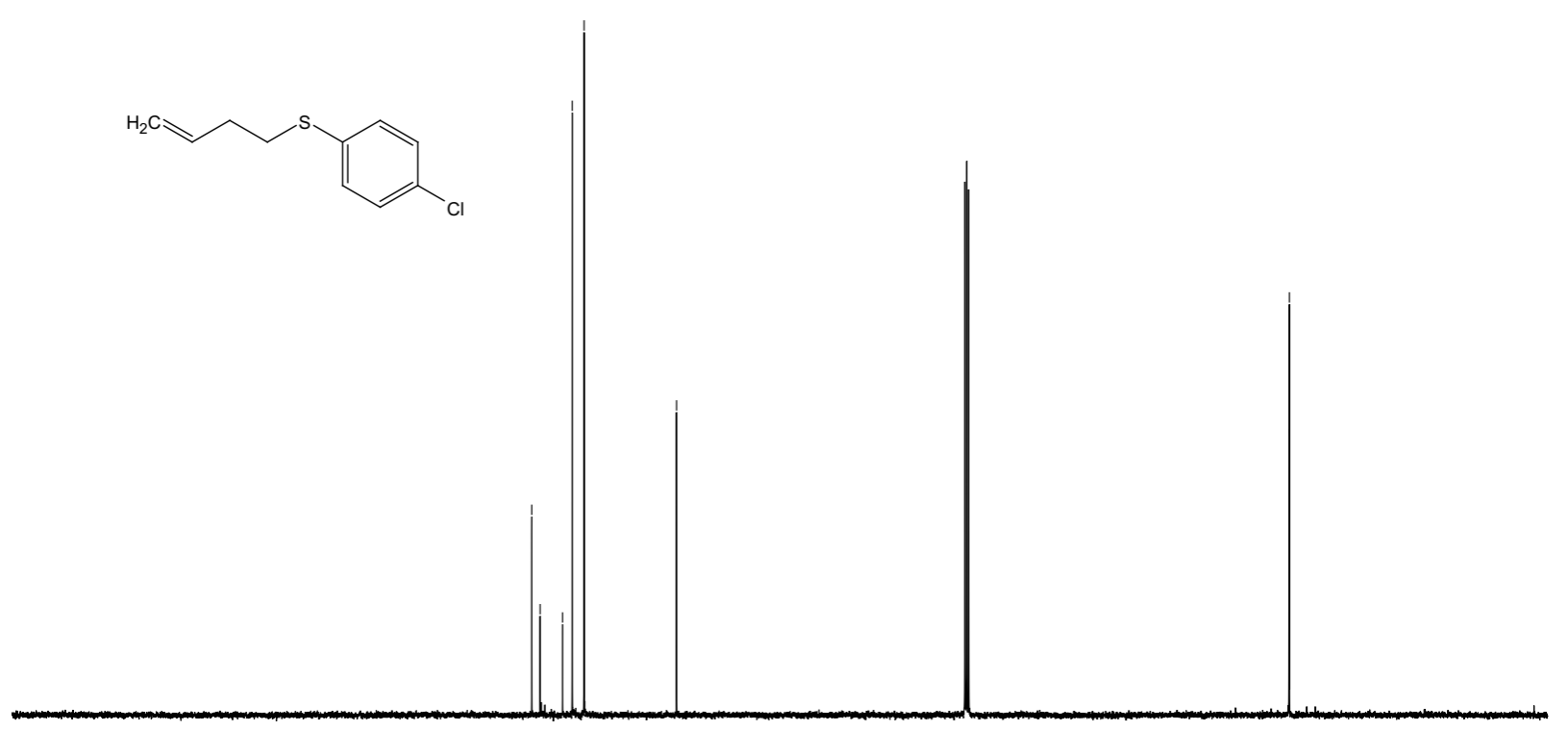

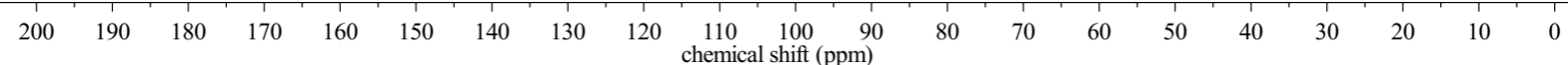


${ }^{1} \mathrm{H}$ NMR spectrum of (4-Bromophenethyl) (4-chlorophenyl) sulfane (16) (400 MHz, $\mathrm{CDCl}_{3}$ ):

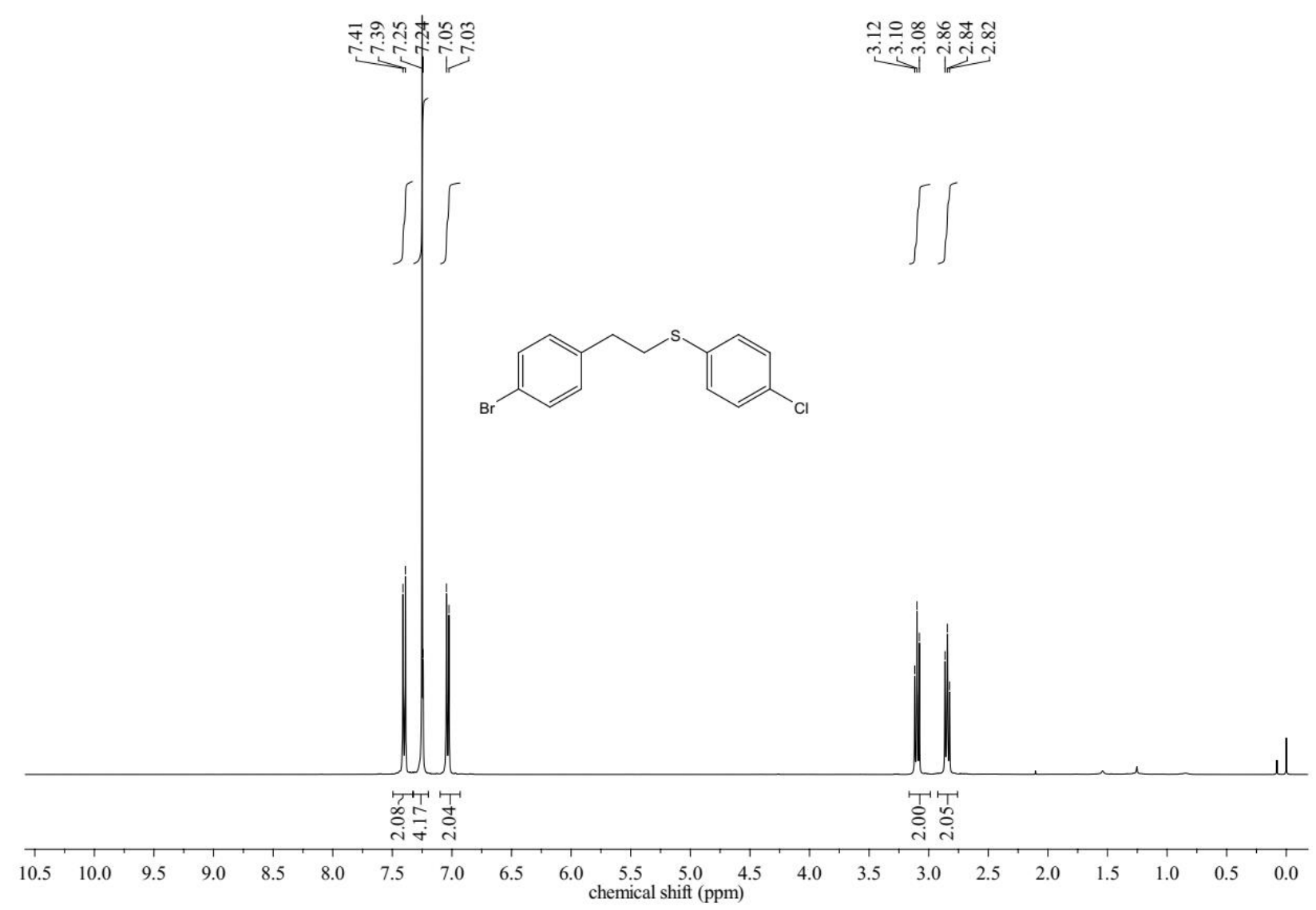

${ }^{13} \mathrm{C}\left\{{ }^{1} \mathrm{H}\right\}$ NMR spectrum of (4-Bromophenethyl) (4-chlorophenyl) sulfane (16) (100 MHz, $\left.\mathrm{CDCl}_{3}\right)$ :

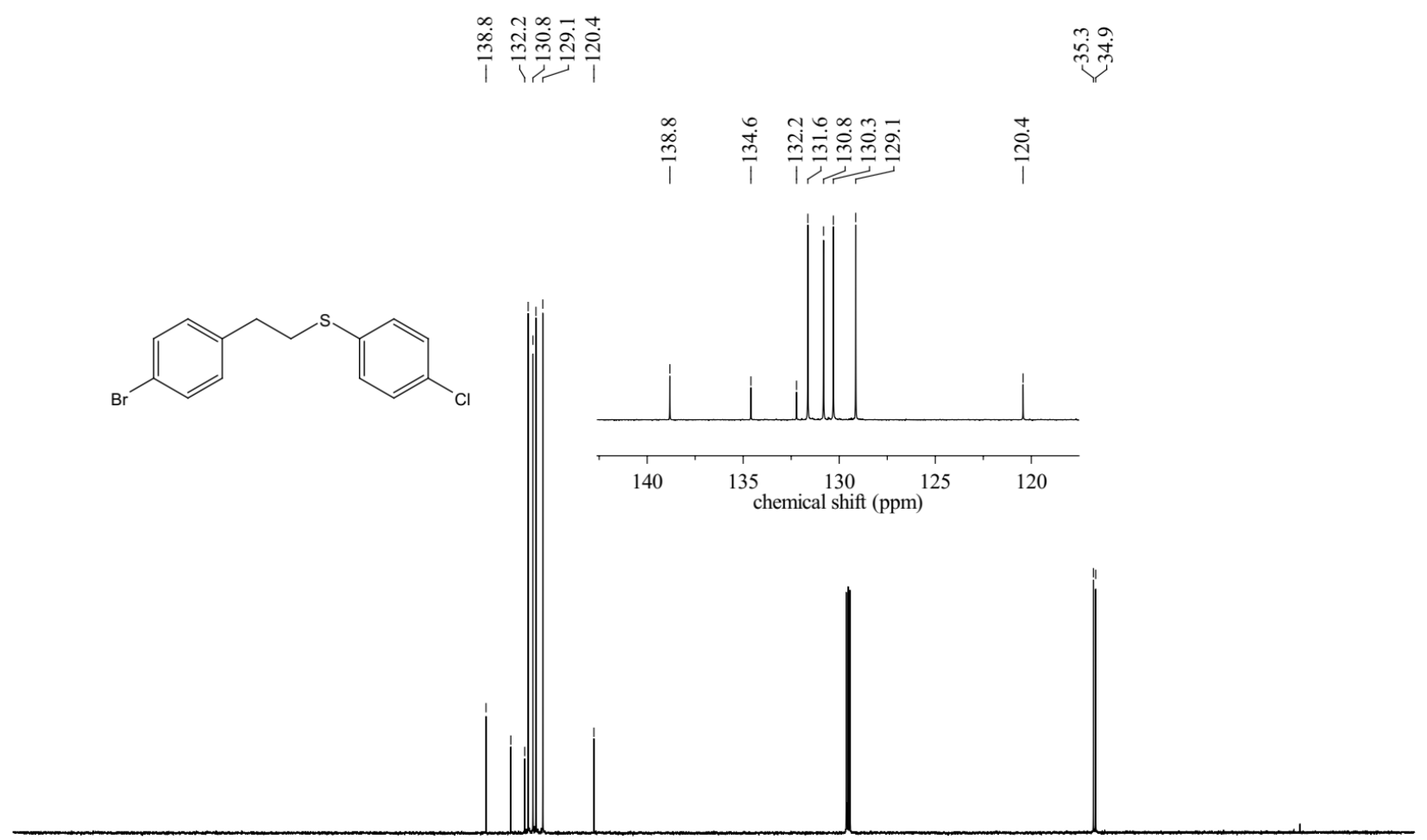

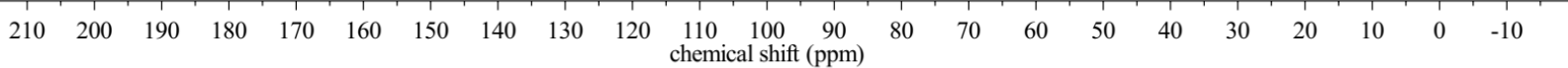


${ }^{1} \mathrm{H}$ NMR spectrum of (4-Bromophenethyl) (4-bromophenyl) sulfane (17) (400 MHz, $\mathrm{CDCl}_{3}$ ):

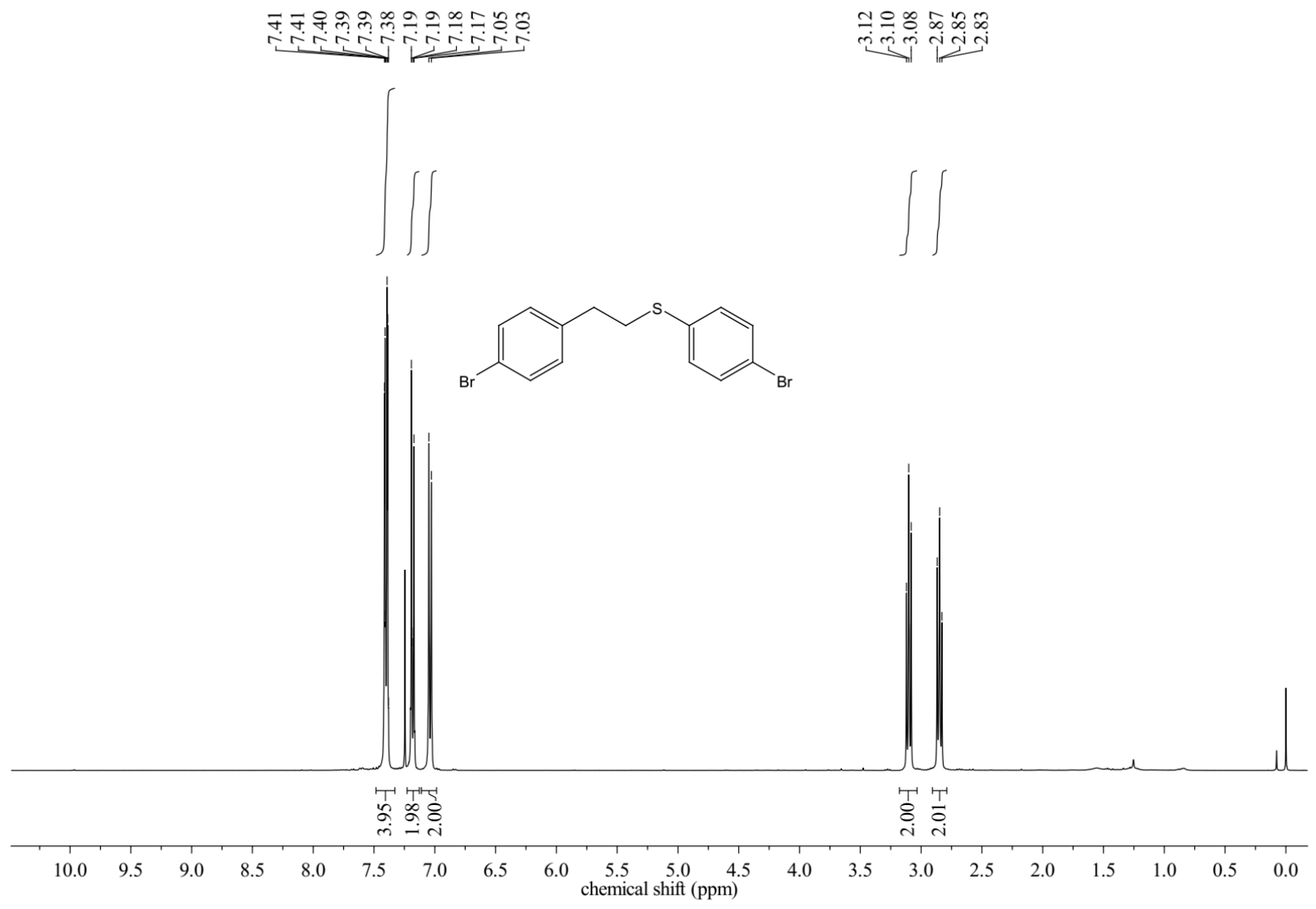

${ }^{13} \mathrm{C}\left\{{ }^{1} \mathrm{H}\right\}$ NMR spectrum of (4-Bromophenethyl) (4-bromophenyl) sulfane (17) (100 MHz, $\mathrm{CDCl}_{3}$ ):

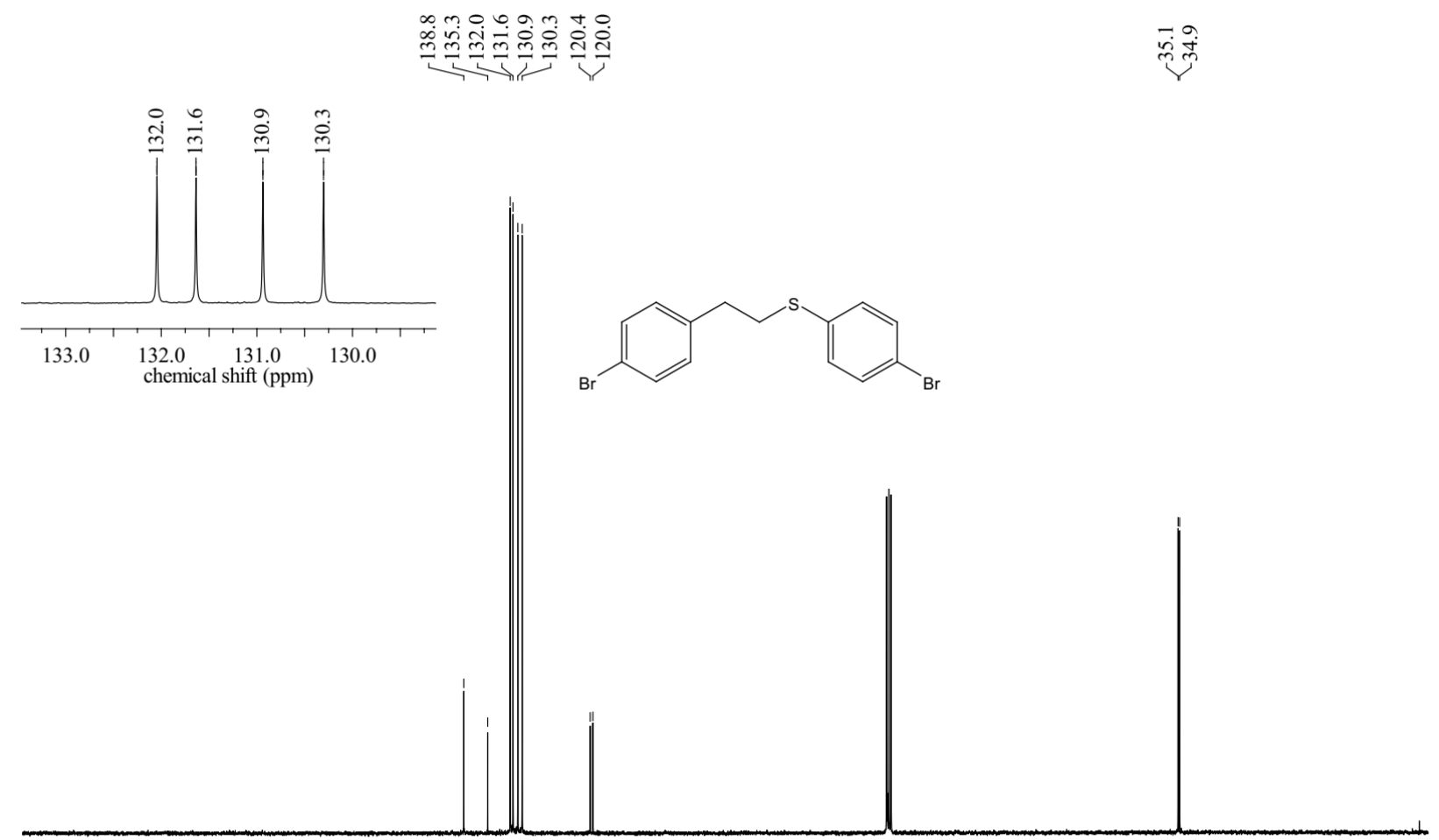

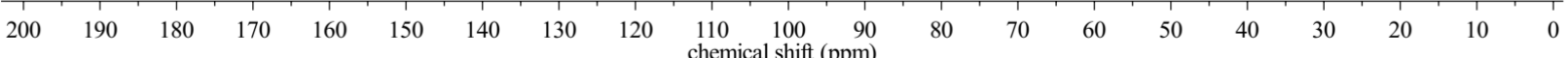


${ }^{1} \mathrm{H}$ NMR spectrum of (4-Chlorophenyl)(1-(4-isobutylphenyl)ethyl) sulfane (18) (500 MHz, $\left.\mathrm{CDCl}_{3}\right)$ :
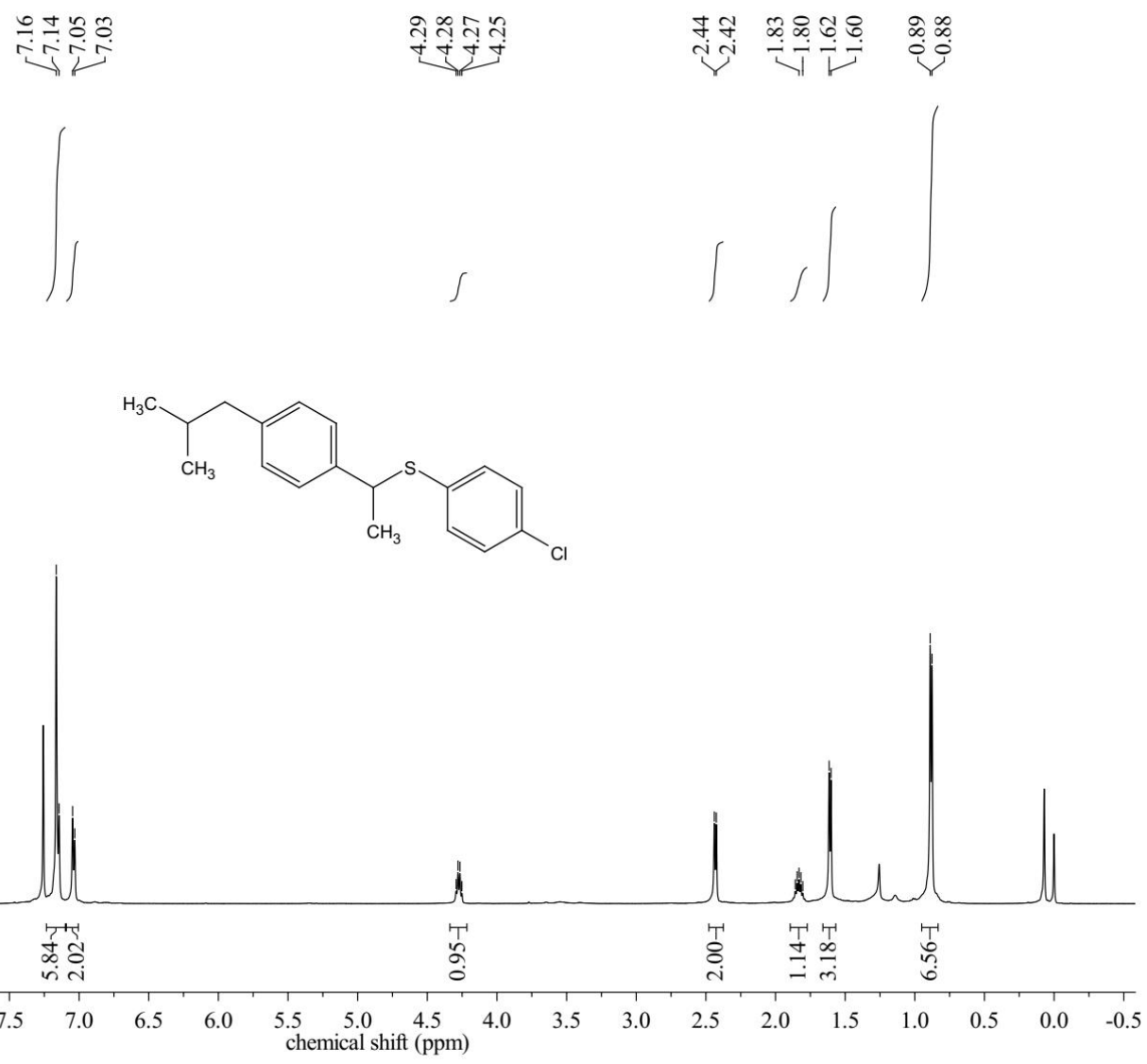

${ }^{13} \mathrm{C}\left\{{ }^{1} \mathrm{H}\right\}$ NMR spectrum of (4-Chlorophenyl)(1-(4-isobutylphenyl)ethyl) sulfane (18) (125 MHz, $\left.\mathrm{CDCl}_{3}\right)$ :

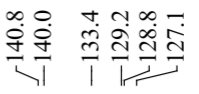

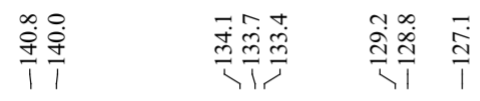
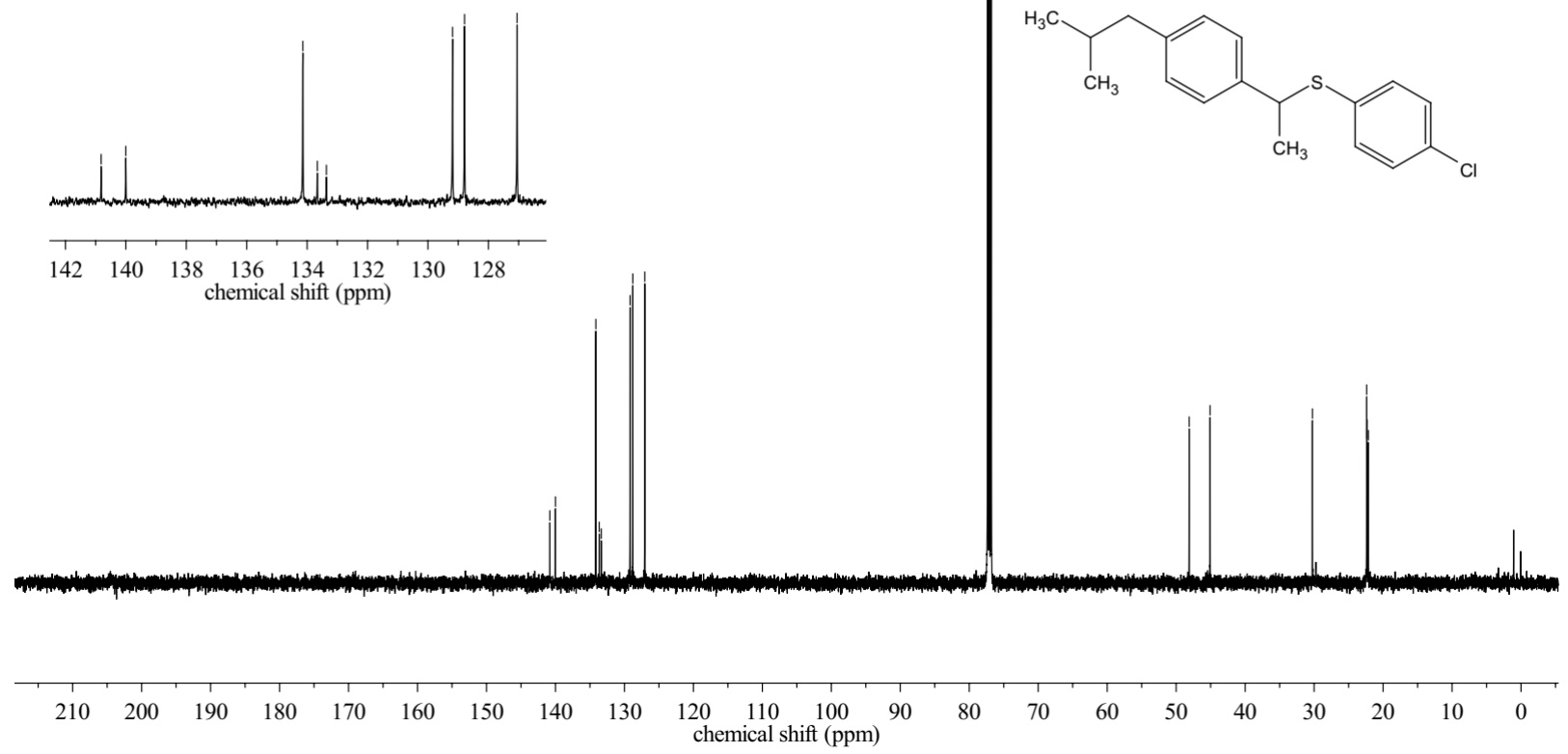

S26 
${ }^{1} \mathrm{H}$ NMR spectrum of tert-Butyl 2-((4-chlorophenyl) thio) piperidine-1-carboxylate (19) (500 MHz, $\left.\mathrm{CDCl}_{3}\right)$ :

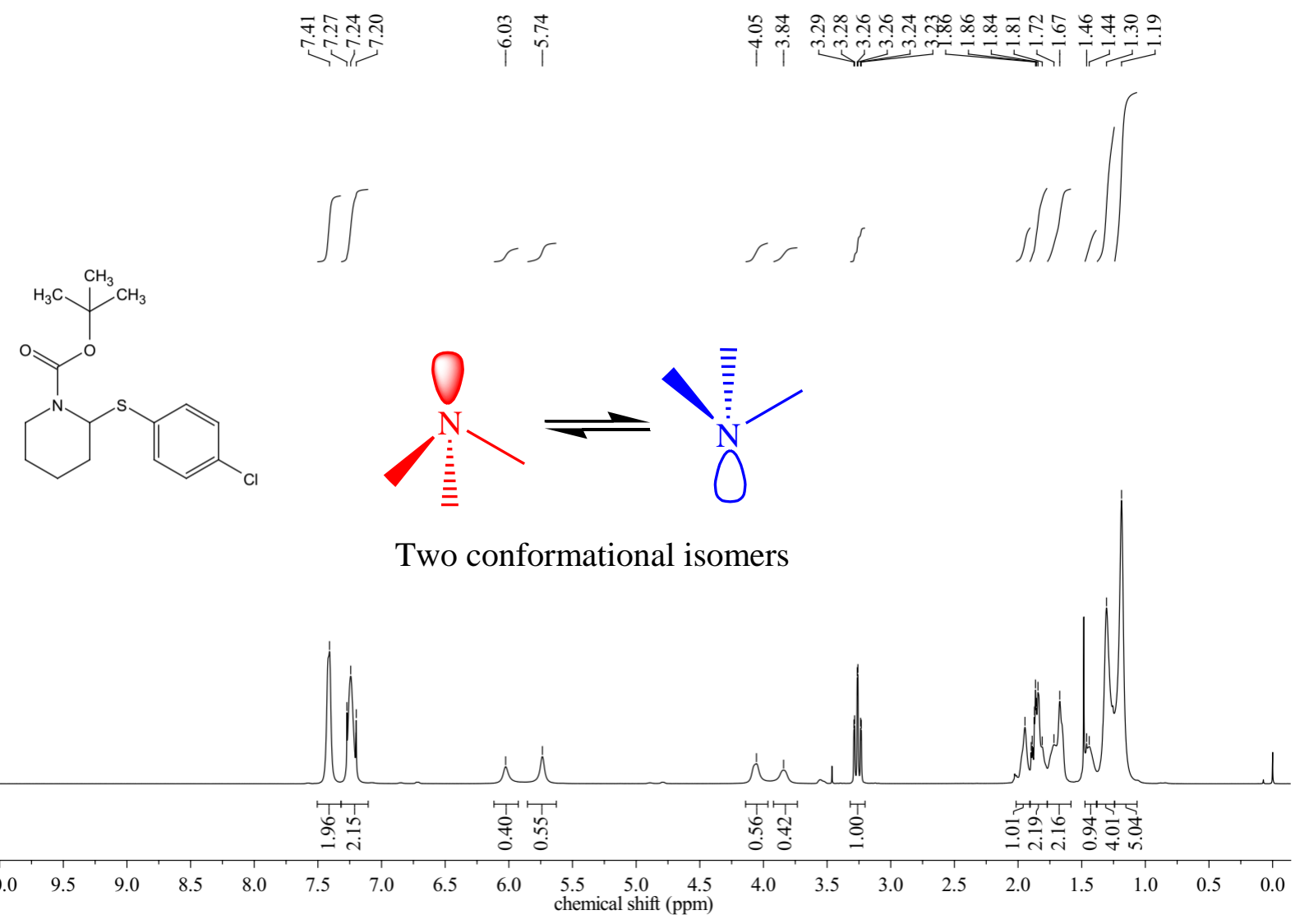

${ }^{13} \mathrm{C}\left\{{ }^{1} \mathrm{H}\right\}$ NMR spectrum of tert-Butyl 2-((4-chlorophenyl) thio) piperidine-1-carboxylate (19) $\left(125 \mathrm{MHz}, \mathrm{CDCl}_{3}\right)$ :

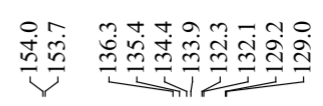

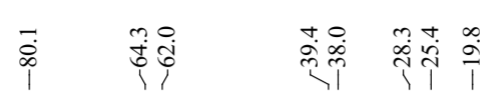
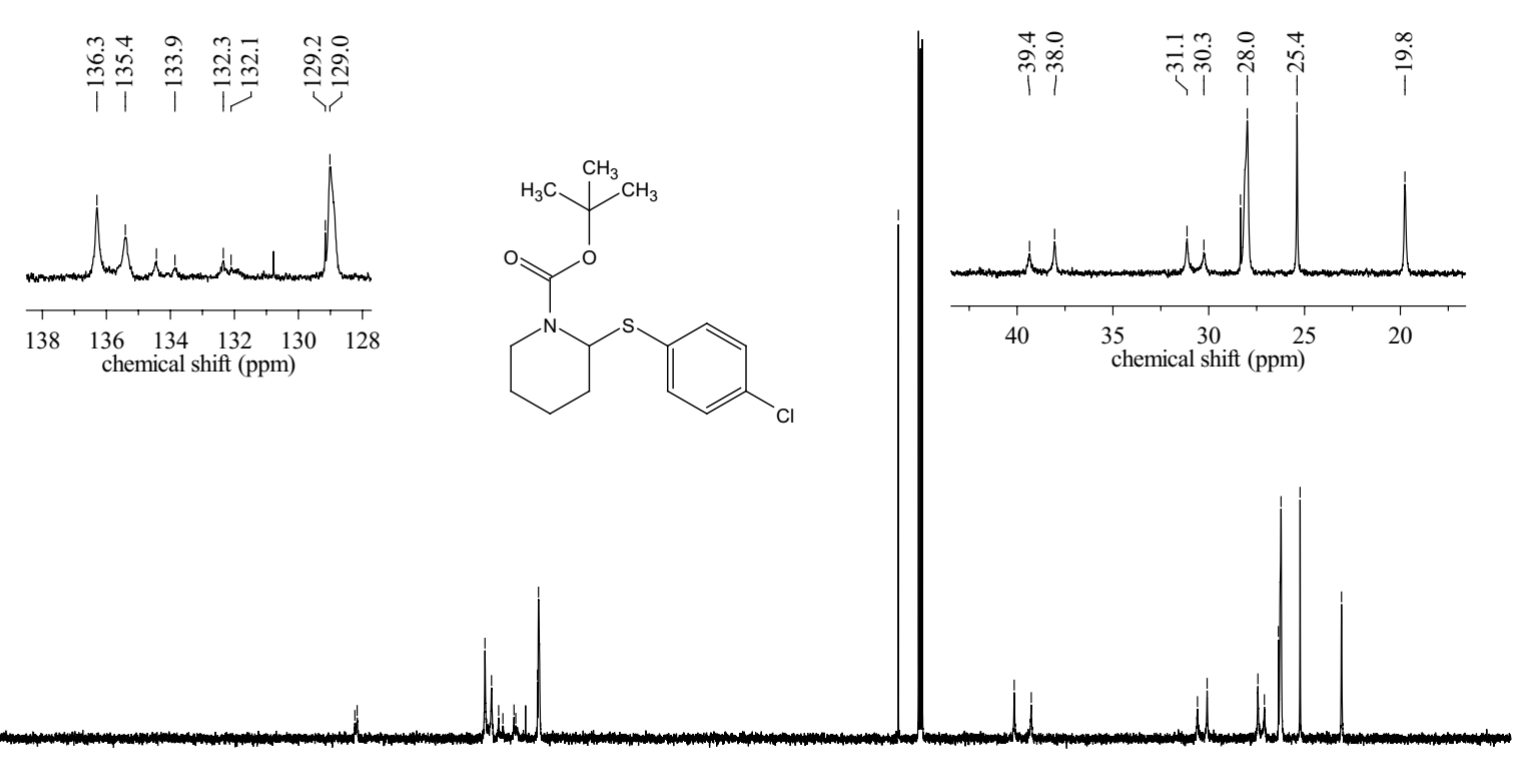

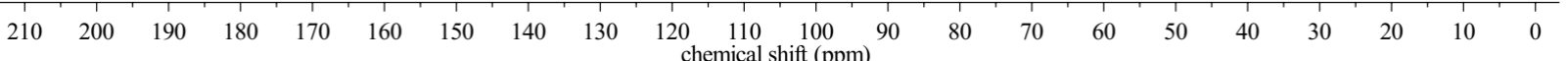


${ }^{1} \mathrm{H}$ NMR spectrum of tert-Butyl 3-((4-fluorophenyl) thio) piperidine-1-carboxylate (20) (500 MHz, $\left.\mathrm{CDCl}_{3}\right)$ :

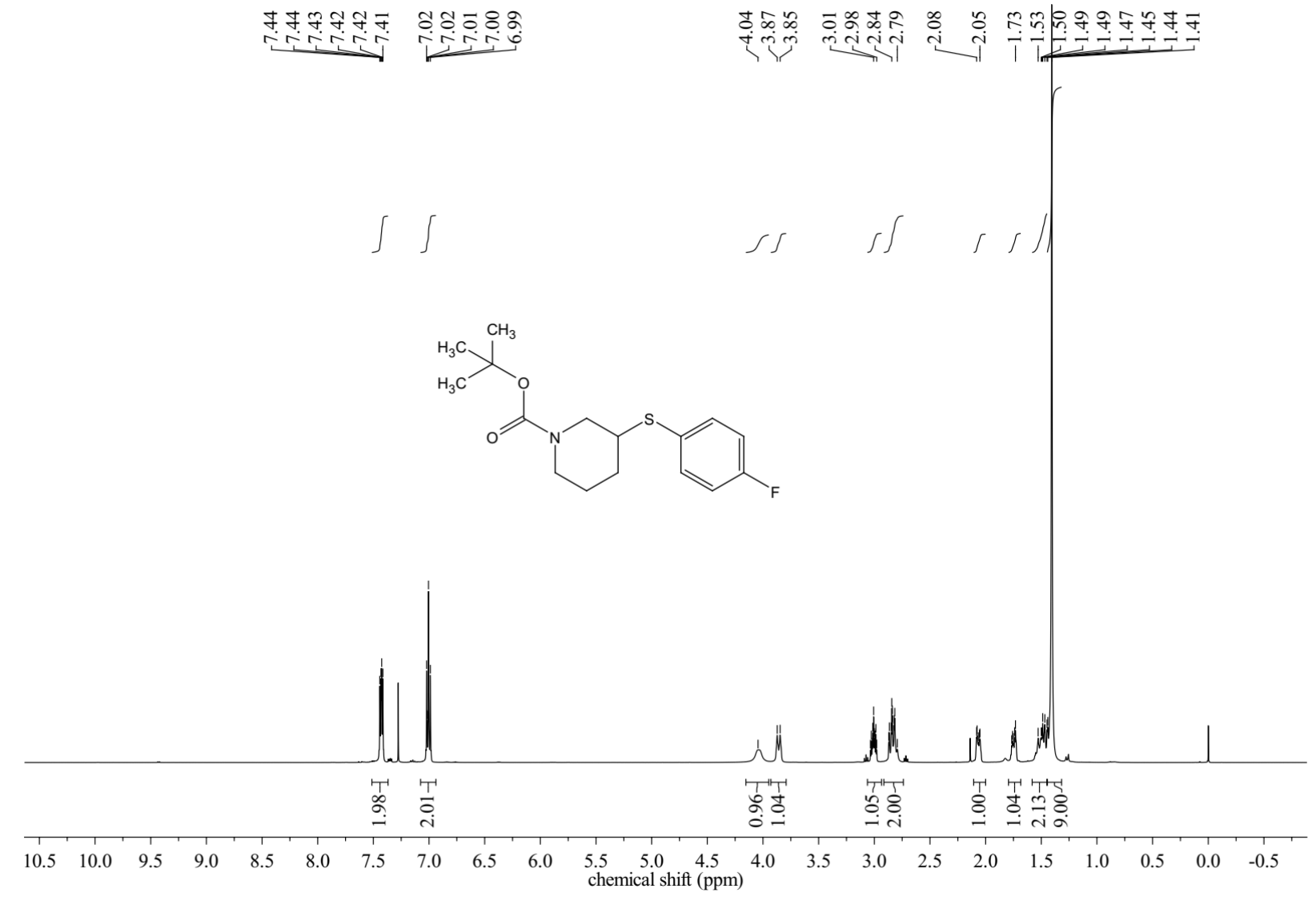

${ }^{13} \mathrm{C}\left\{{ }^{1} \mathrm{H}\right\}$ NMR spectrum of tert-Butyl 3-((4-fluorophenyl) thio) piperidine-1-carboxylate (20) $\left(125 \mathrm{MHz}, \mathrm{CDCl}_{3}\right)$ :

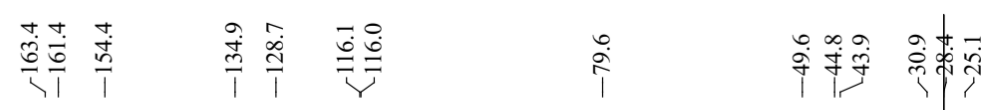

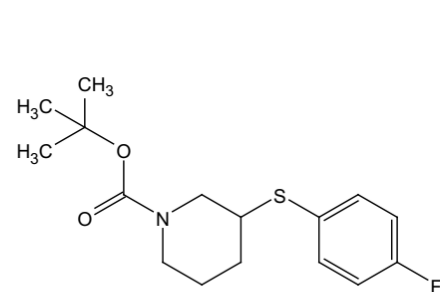

$\begin{array}{llllllllllll}210 & 200 & 190 & 180 & 170 & 160 & 150 & 140 & 130 & 120 & 110 & 100 \\ \text { chemical shift (ppm) }\end{array}$ 
${ }^{19} \mathrm{~F}$ NMR spectrum of tert-Butyl 3-((4-fluorophenyl) thio) piperidine-1-carboxylate (20) (375 $\left.\mathrm{MHz}, \mathrm{CDCl}_{3}\right)$ :

$\stackrel{\stackrel{7}{7}}{i}$
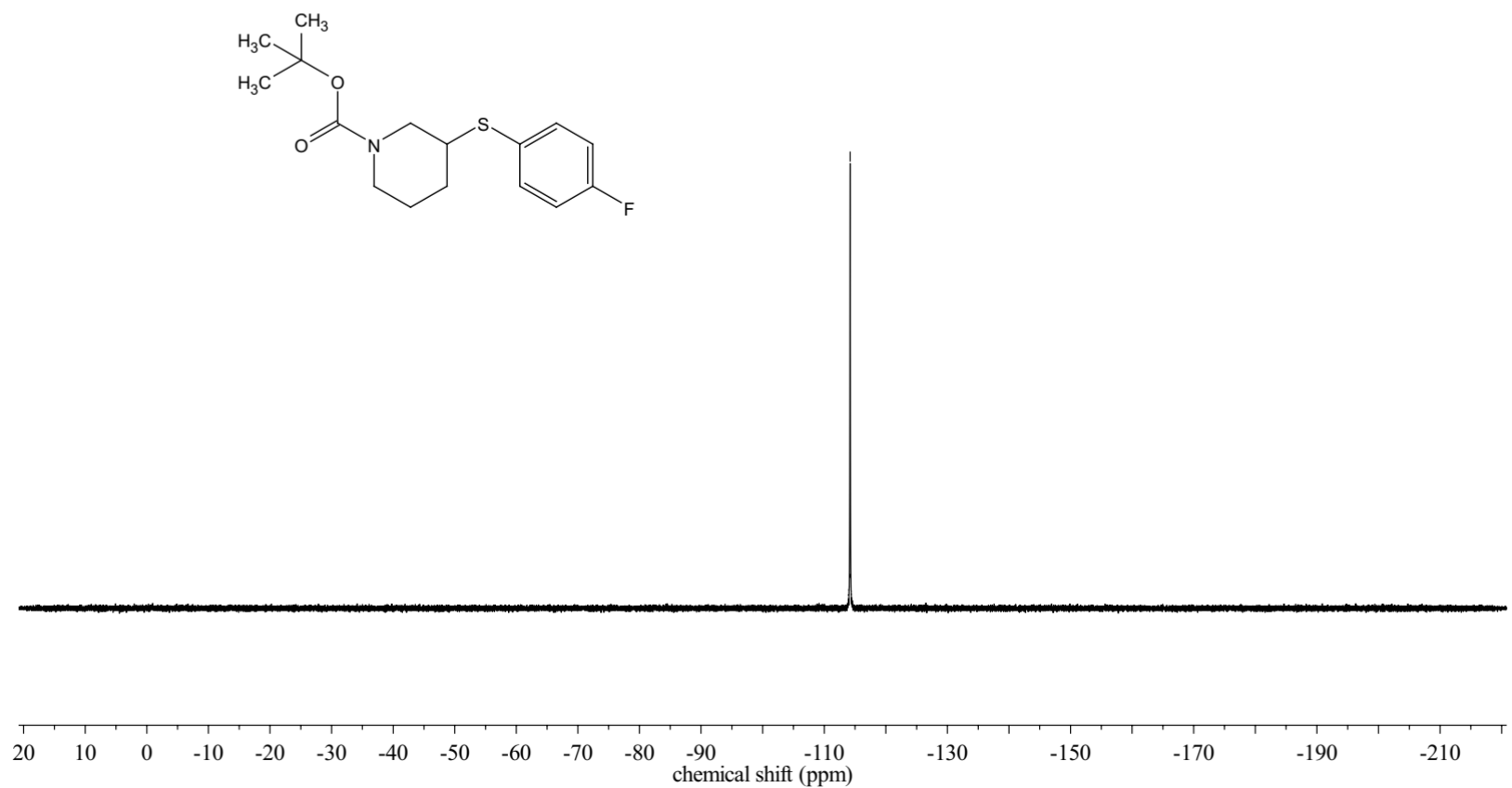

${ }^{1} \mathrm{H}$ NMR spectrum of tert-Butyl 3-((4-chlorophenyl) thio) piperidine-1-carboxylate (21) (400 $\left.\mathrm{MHz}, \mathrm{CDCl}_{3}\right)$ :

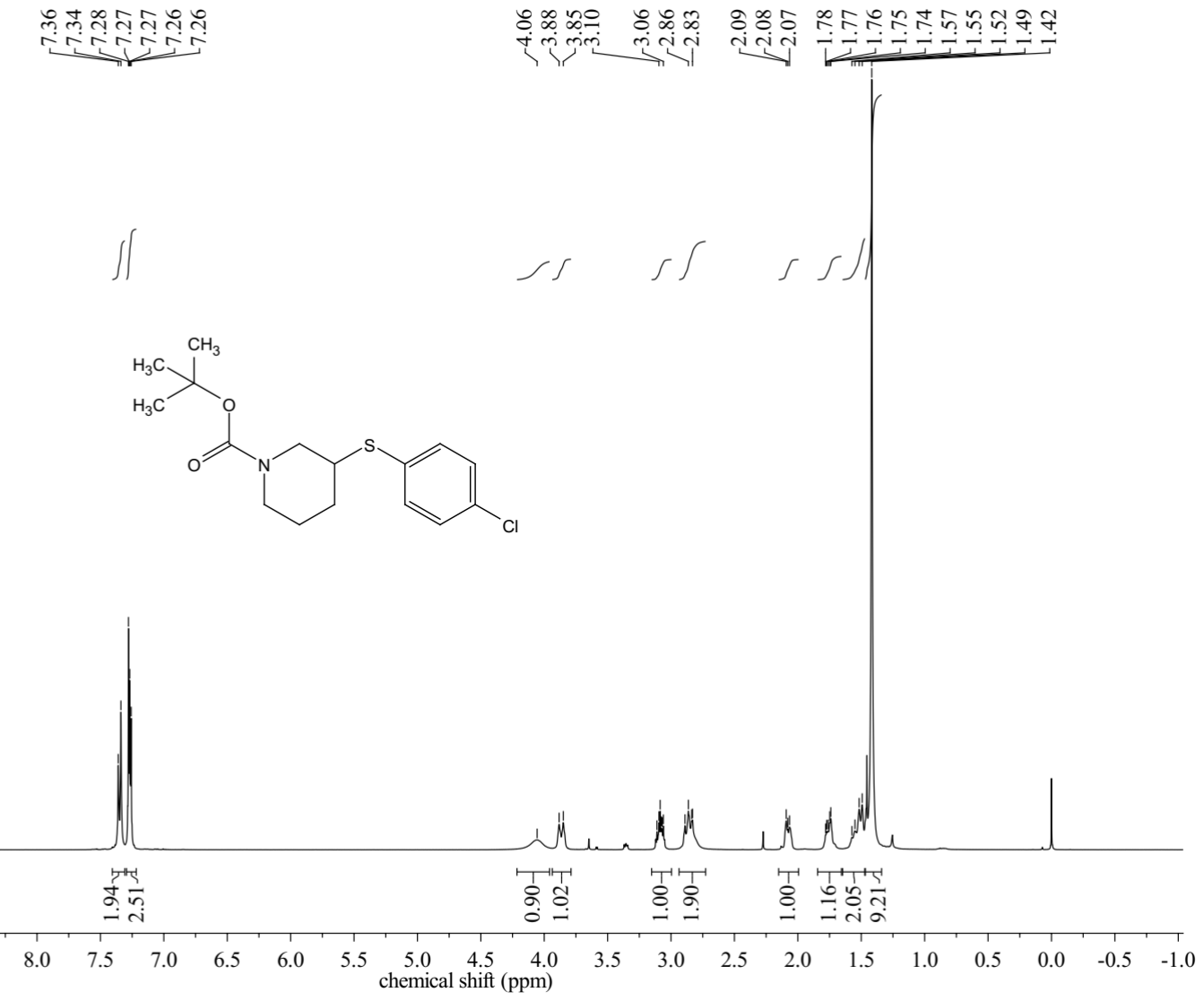

S29 
${ }^{13} \mathrm{C}\left\{{ }^{1} \mathrm{H}\right\}$ NMR spectrum of tert-Butyl 3-((4-chlorophenyl) thio) piperidine-1-carboxylate (21) $\left(100 \mathrm{MHz}, \mathrm{CDCl}_{3}\right)$ :

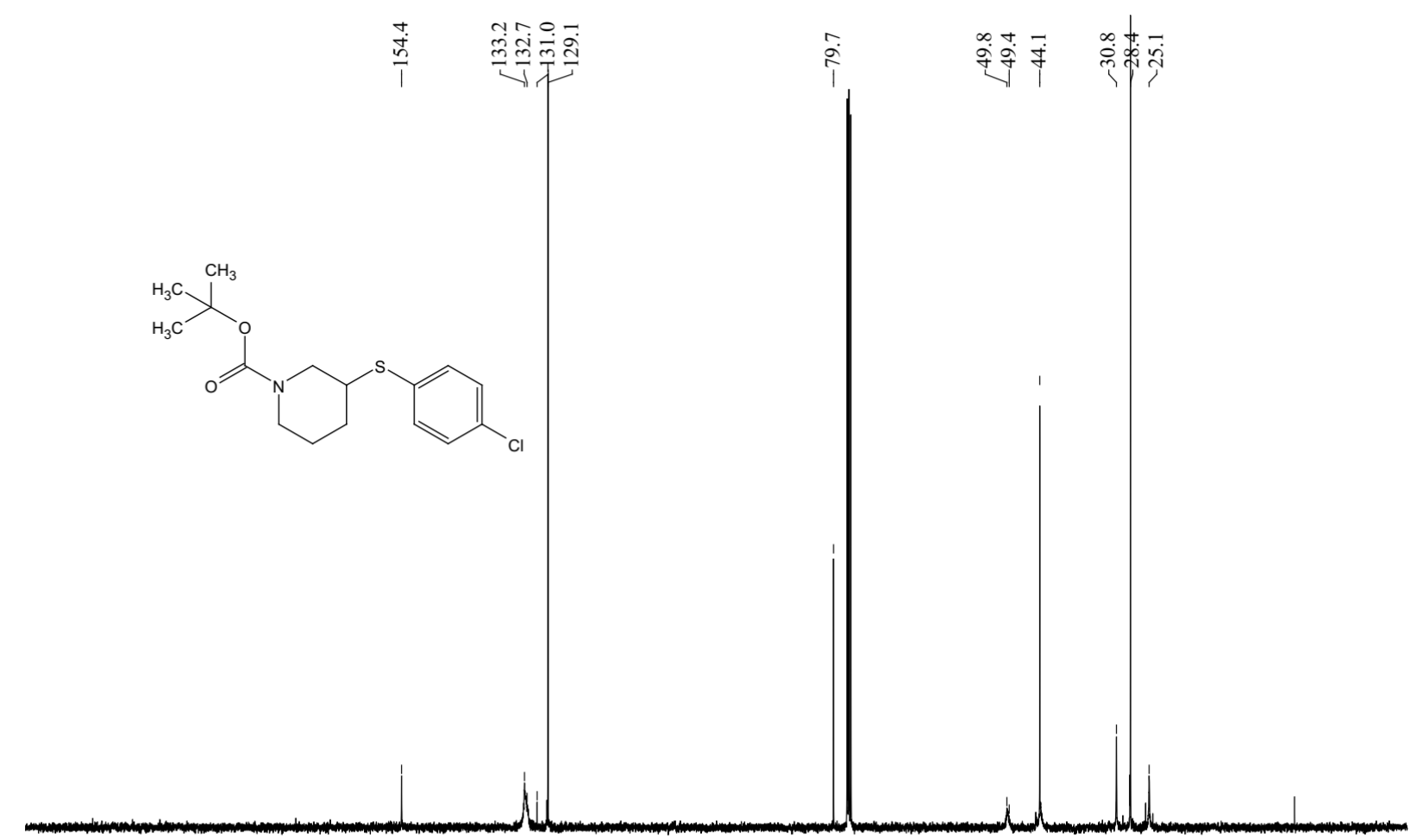

$\begin{array}{llllllllllllllllllllllllllll}210 & 200 & 190 & 180 & 170 & 160 & 150 & 140 & 130 & 120 & \begin{array}{c}110 \\ \text { chemical shift }(\mathrm{ppm})\end{array} & 80 & 70 & 60 & 50 & 40 & 30 & 20 & 10 & 0 & -10\end{array}$

${ }^{1} \mathrm{H}$ NMR spectrum of tert-Butyl 3-((4-bromophenyl) thio) piperidine-1-carboxylate (22) $\left(500 \mathrm{MHz}, \mathrm{CDCl}_{3}\right)$ :

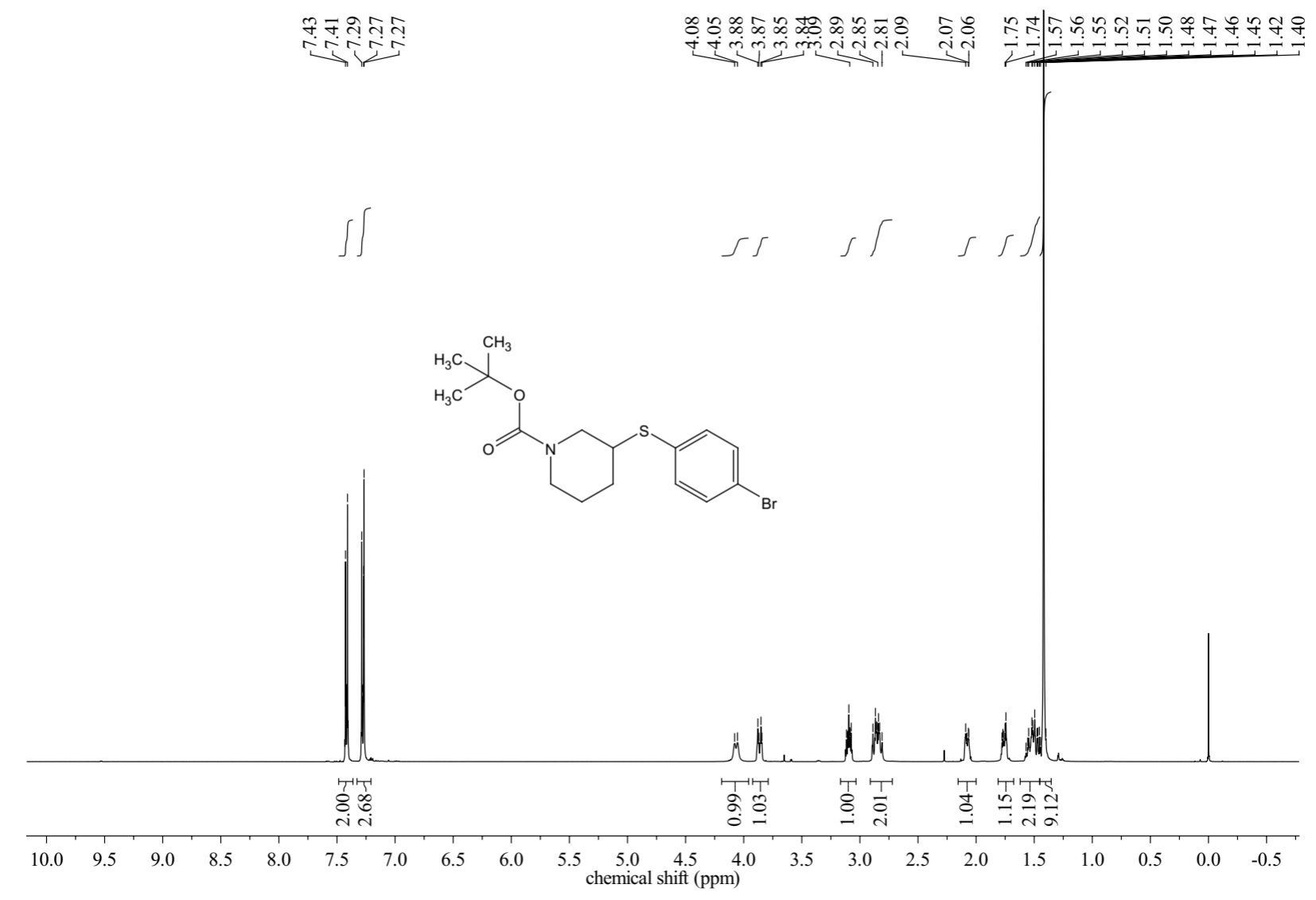


${ }^{13} \mathrm{C}\left\{{ }^{1} \mathrm{H}\right\}$ NMR spectrum of tert-Butyl 3-((4-bromophenyl) thio) piperidine-1-carboxylate (22) (125 MHz, $\left.\mathrm{CDCl}_{3}\right)$ :
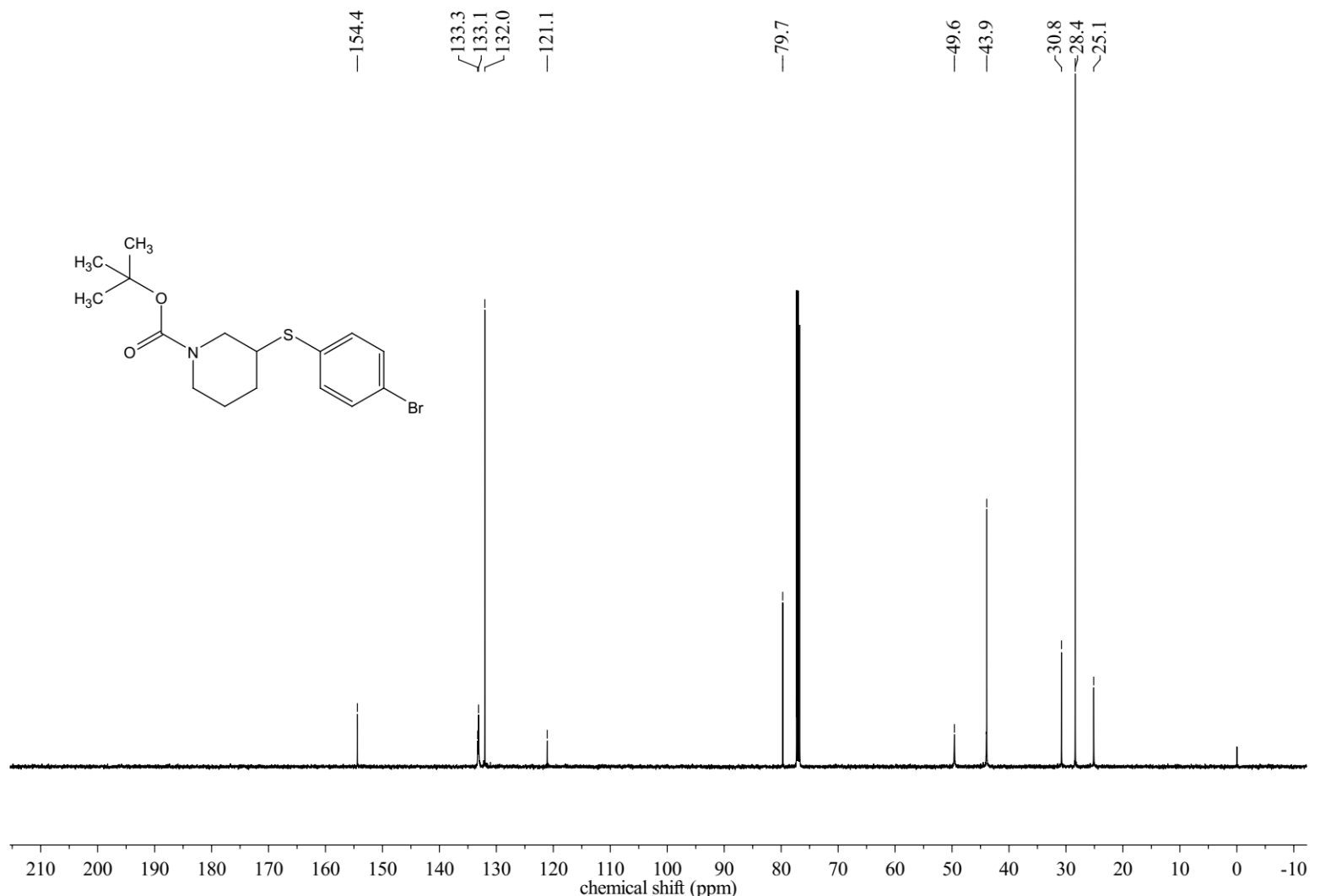

${ }^{1} \mathrm{H}$ NMR spectrum of tert-Butyl 4-((4-fluorophenyl) thio) piperidine-1-carboxylate (23) $\left(500 \mathrm{MHz}, \mathrm{CDCl}_{3}\right)$ :

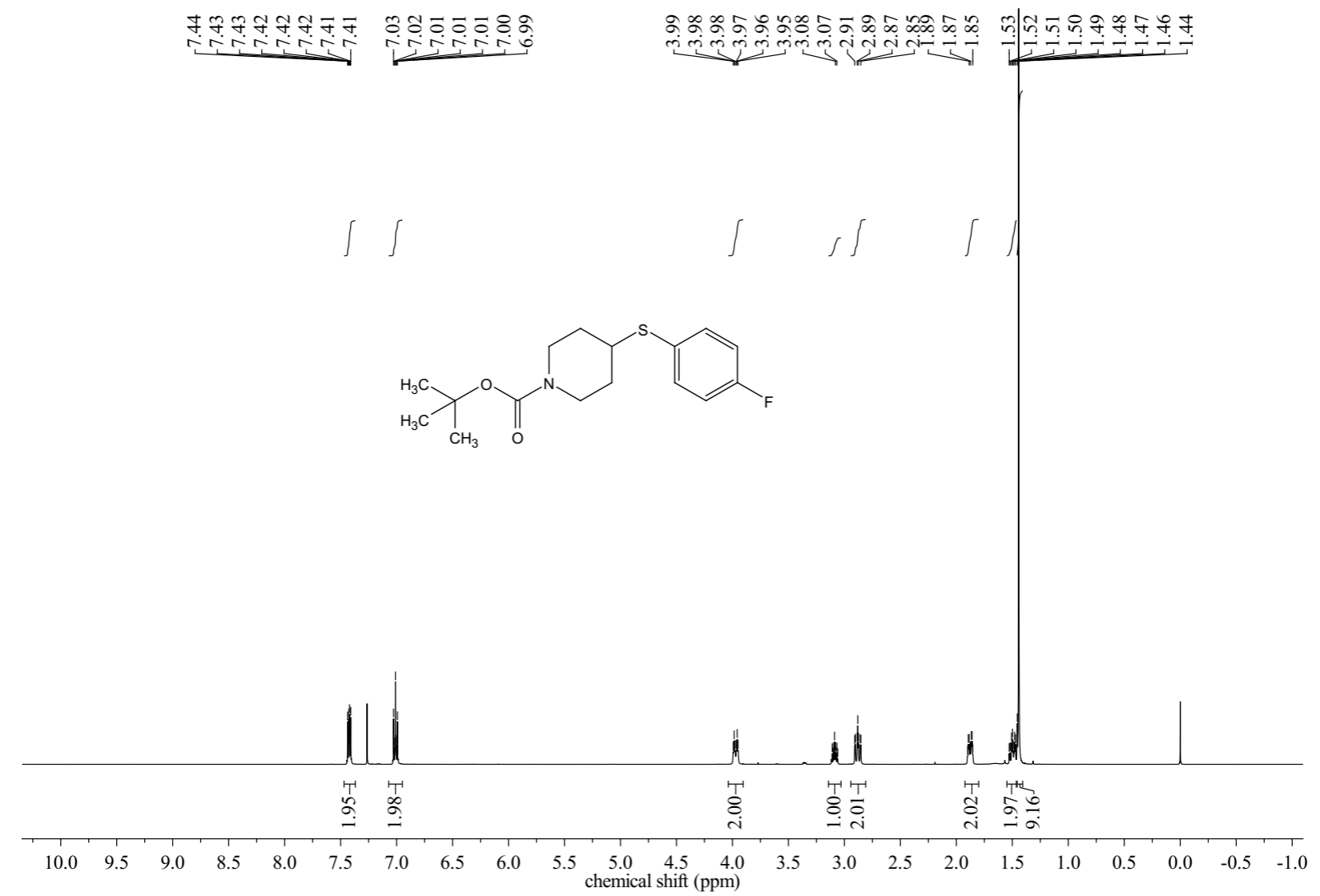


${ }^{13} \mathrm{C}\left\{{ }^{1} \mathrm{H}\right\}$ NMR spectrum of tert-Butyl 4-((4-fluorophenyl) thio) piperidine-1-carboxylate (23) $\left(125 \mathrm{MHz}, \mathrm{CDCl}_{3}\right)$ :
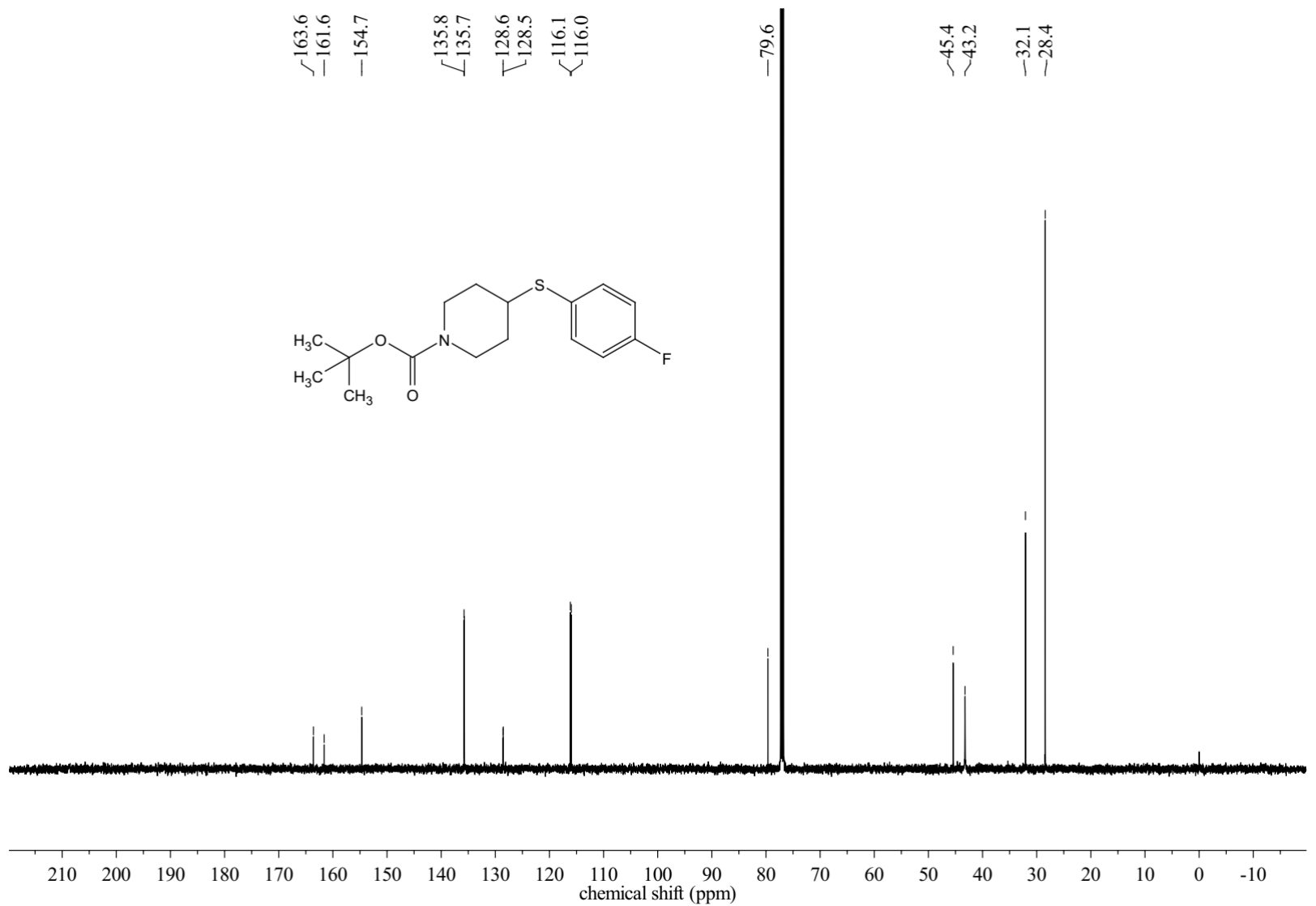

${ }^{19} \mathrm{~F}$ NMR spectrum of tert-Butyl 4-((4-fluorophenyl) thio) piperidine-1-carboxylate (23) $\left(375 \mathrm{MHz}, \mathrm{CDCl}_{3}\right)$ :

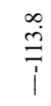<smiles>CC(C)(C)OC(=O)N1CCC(Sc2ccc(F)cc2)CC1</smiles>

$\begin{array}{llllllllllllllllllll}40 & 30 & 20 & 10 & 0 & -10 & -30 & -50 & -70 & -90 & -110 & -130 & -150 & -170 & -190 & -210 & -230 & \\ \text { chemical shift }(\mathrm{ppm}) & & & & & & & \end{array}$


${ }^{1} \mathrm{H}$ NMR spectrum of tert-Butyl 4-((4-chlorophenyl) thio) piperidine-1-carboxylate (24) (500 $\left.\mathrm{MHz}, \mathrm{CDCl}_{3}\right)$ :

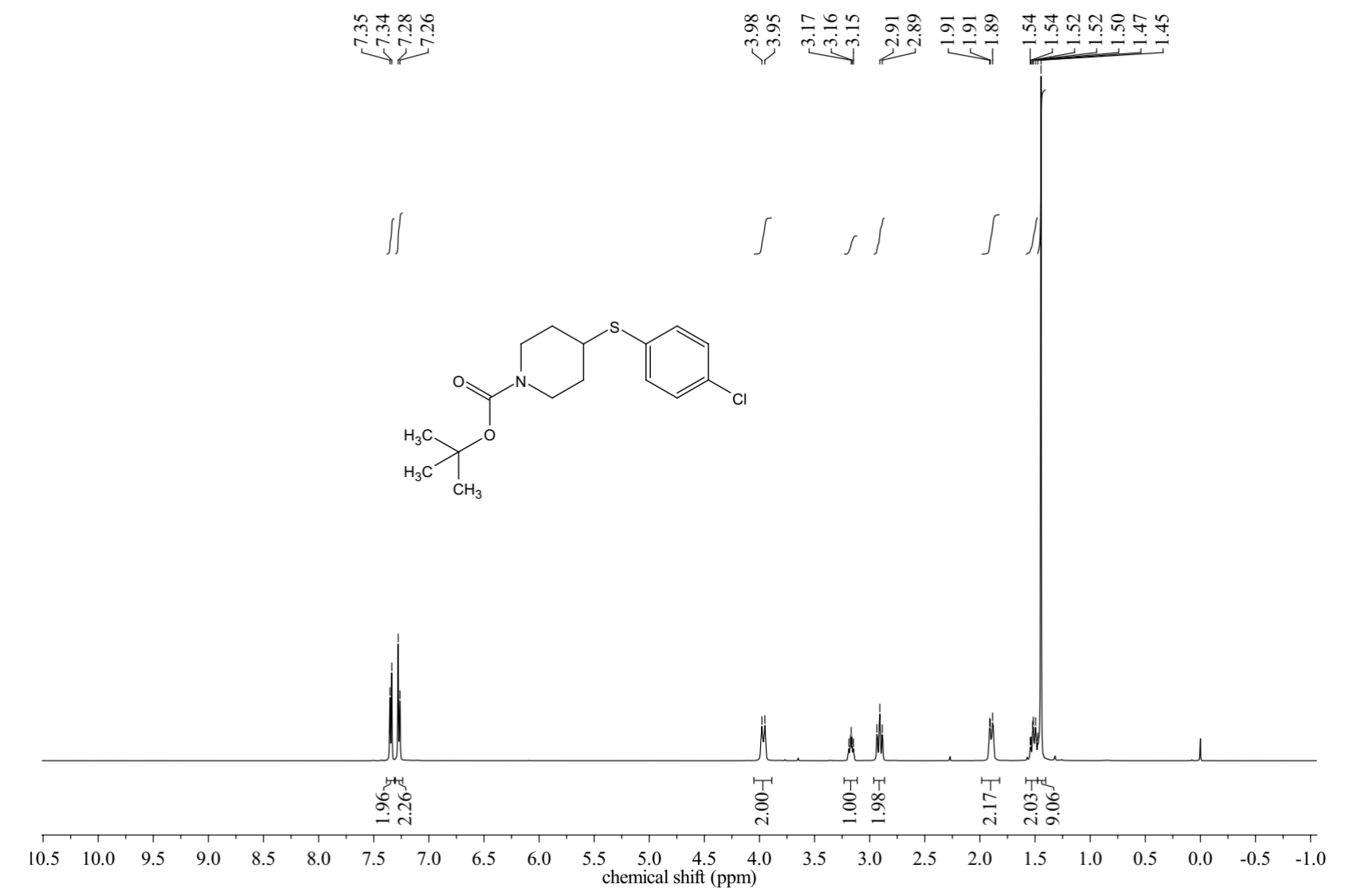

${ }^{13} \mathrm{C}\left\{{ }^{1} \mathrm{H}\right\}$ NMR spectrum of tert-Butyl 4-((4-chlorophenyl) thio) piperidine-1-carboxylate (24) (125 MHz, $\left.\mathrm{CDCl}_{3}\right)$ :

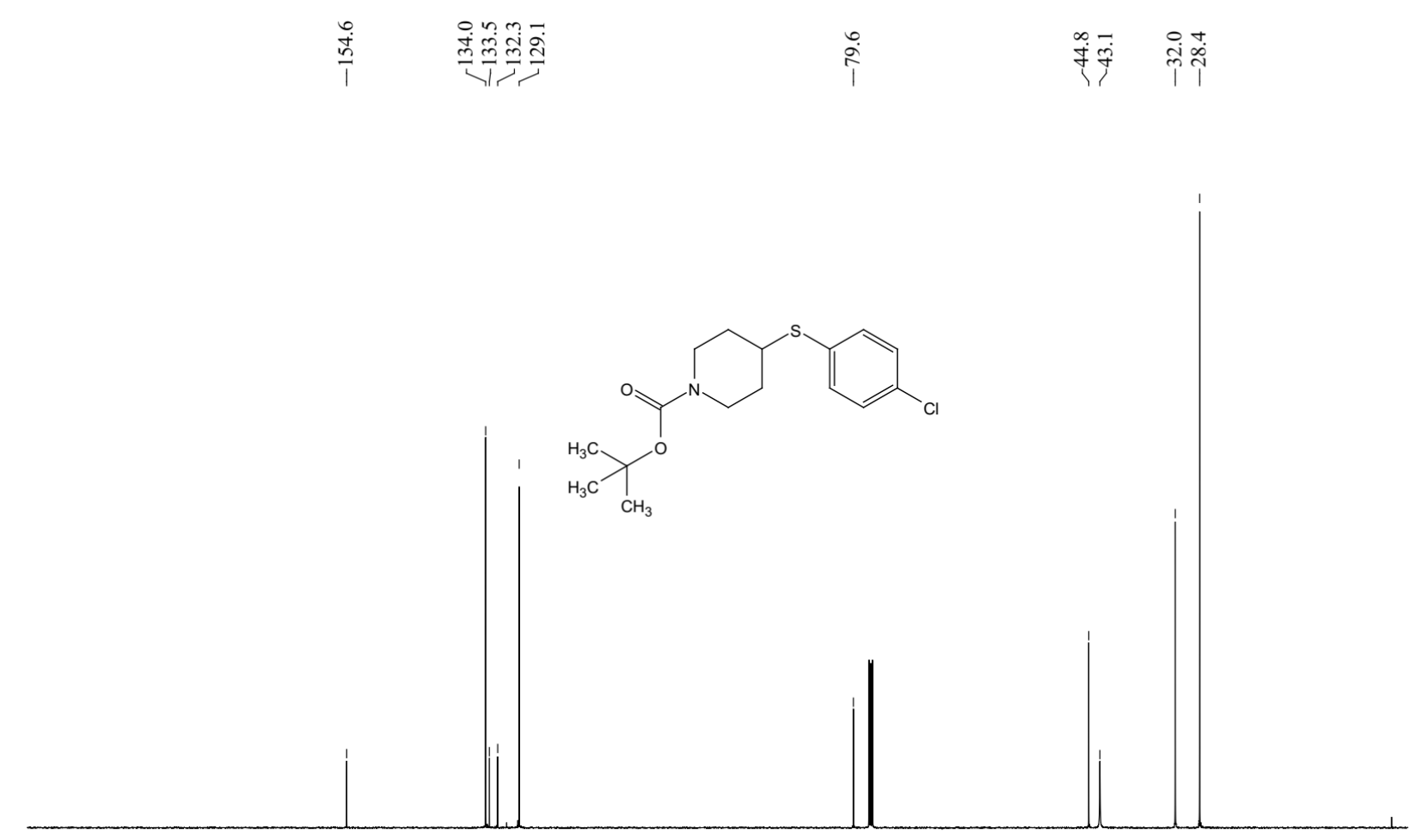

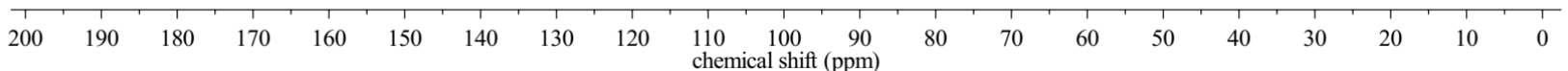


${ }^{1} \mathrm{H}$ NMR spectrum of tert-Butyl (1-((4-chlorophenyl) thio) ethyl) carbamate (25) (500 MHz, $\left.\mathrm{CDCl}_{3}\right)$ :

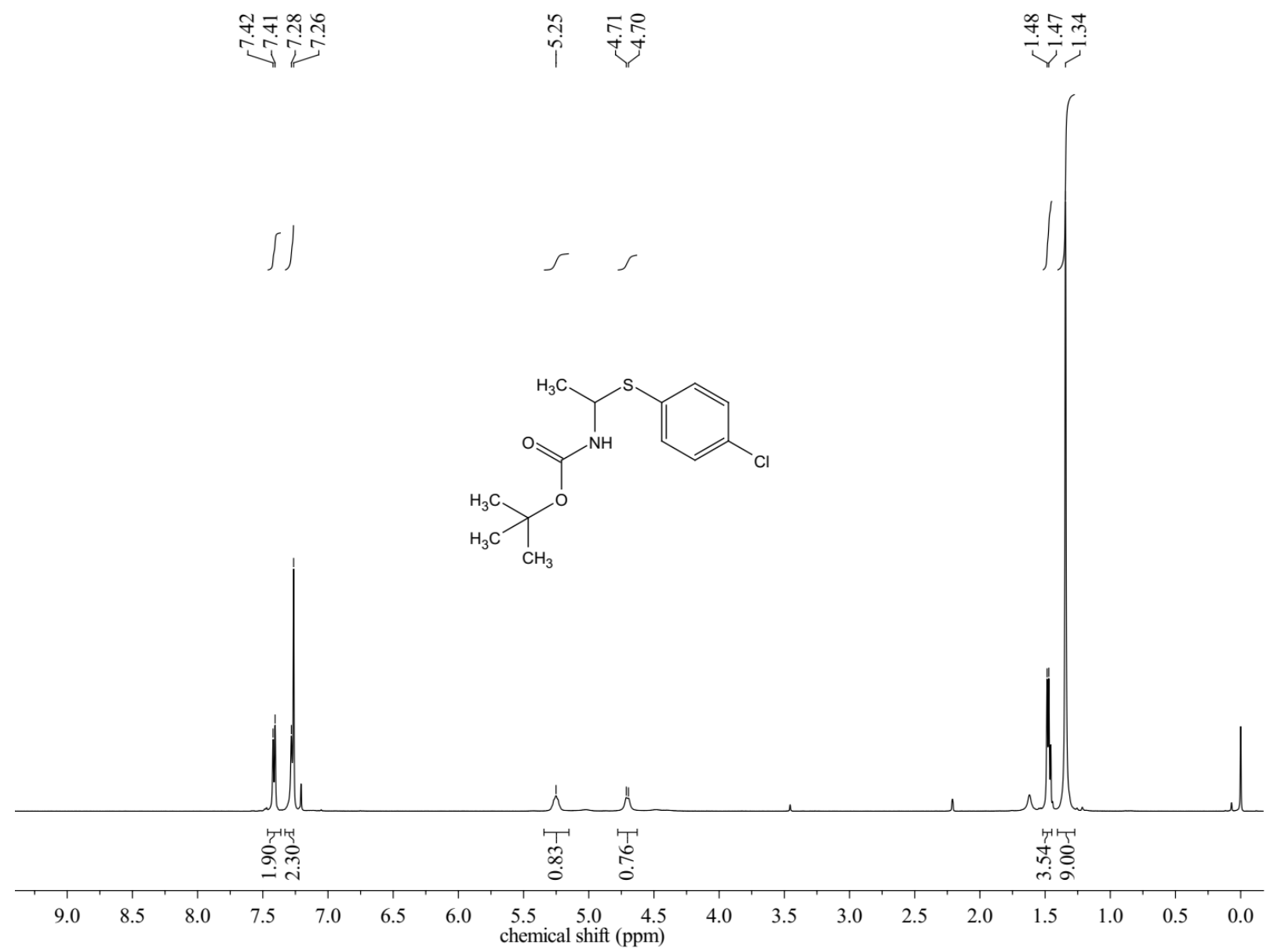

${ }^{13} \mathrm{C}\left\{{ }^{1} \mathrm{H}\right\}$ NMR spectrum of tert-Butyl (1-((4-chlorophenyl) thio) ethyl) carbamate (25) $\left(125 \mathrm{MHz}, \mathrm{CDCl}_{3}\right)$ :

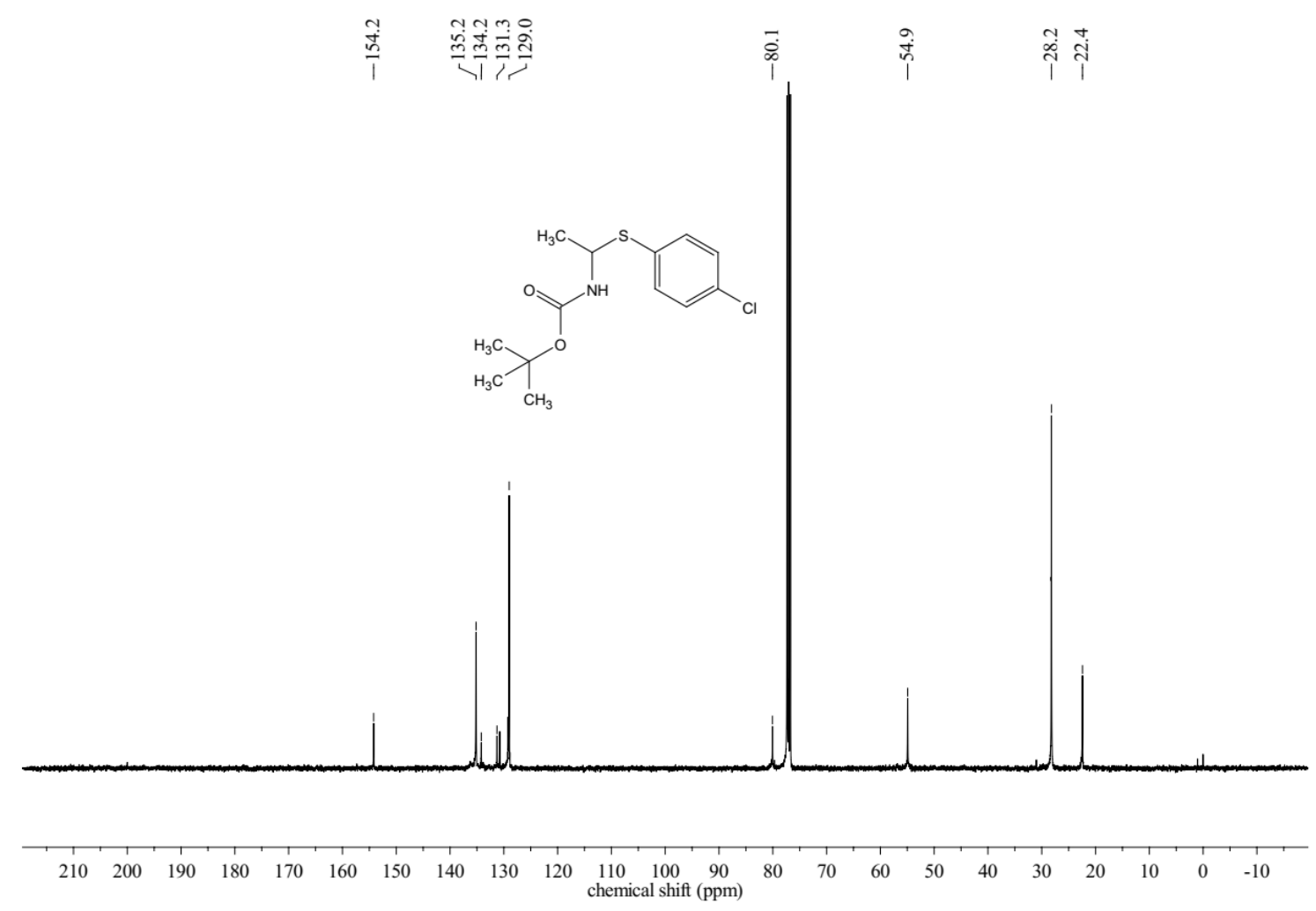


${ }^{1} \mathrm{H}$ NMR spectrum of tert-Butyl (1-((4-chlorophenyl) thio)-3-(methylthio) propyl) carbamate (26) (500 MHz, $\mathrm{CDCl}_{3}$ ):

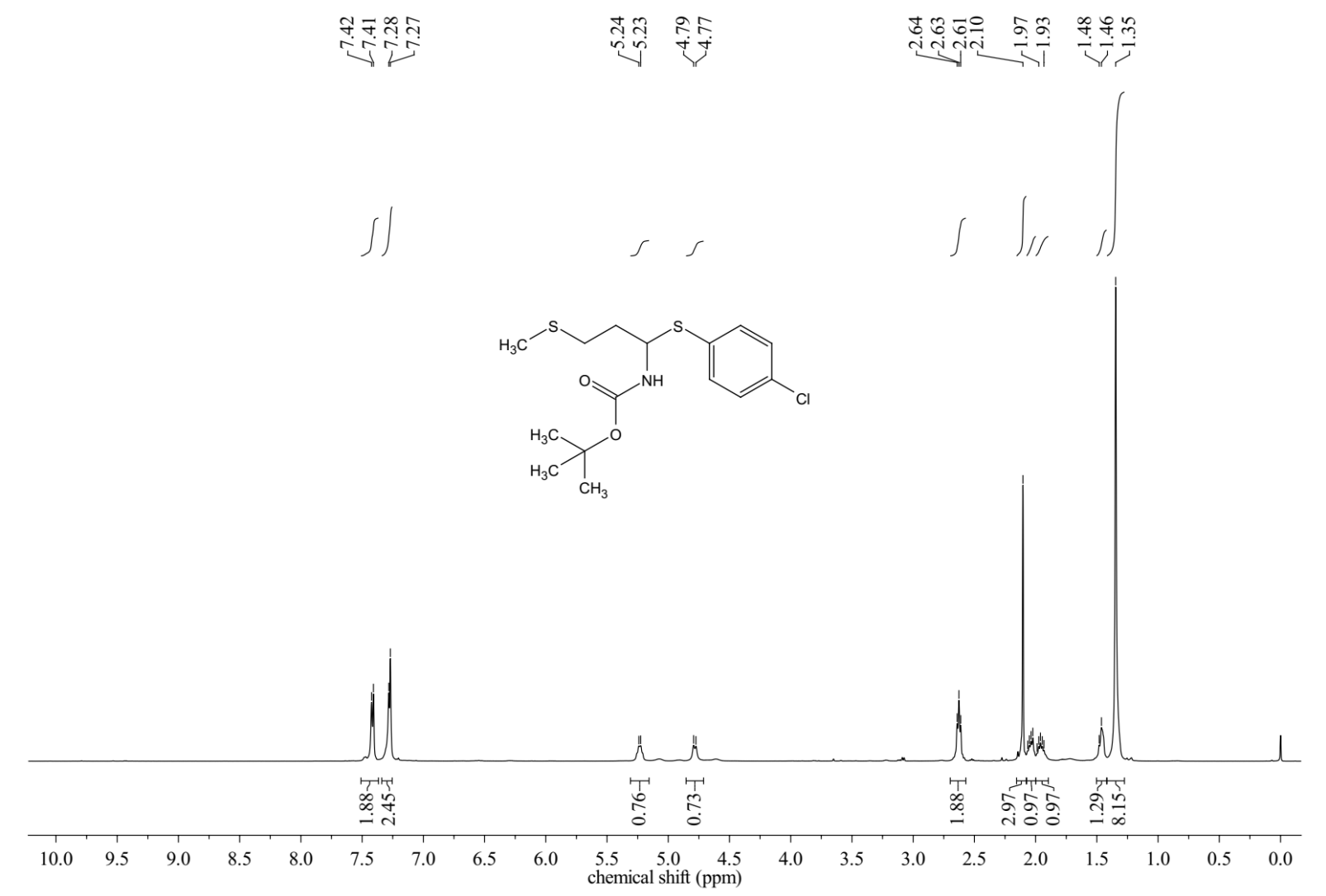

${ }^{13} \mathrm{C}\left\{{ }^{1} \mathrm{H}\right\}$ NMR spectrum of tert-Butyl (1-((4-chlorophenyl) thio)-3-(methylthio) propyl) carbamate (26) (125 $\mathrm{MHz}, \mathrm{CDCl}_{3}$ ):

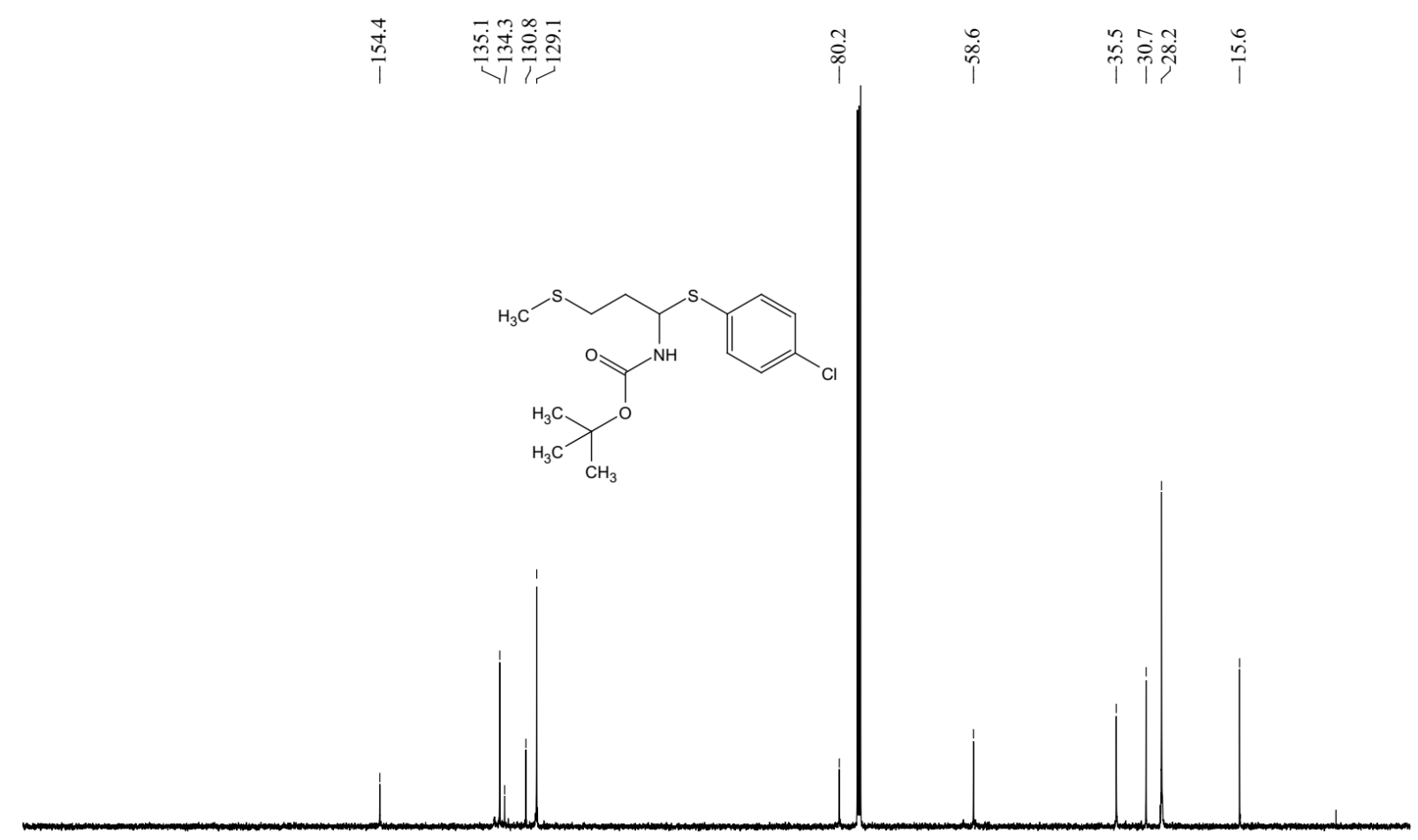

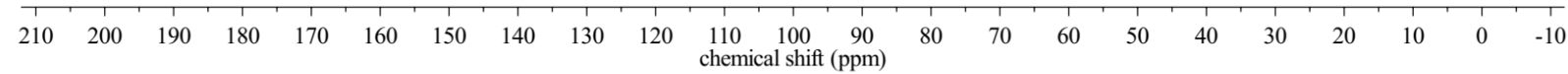


${ }^{1} \mathrm{H}$ NMR spectrum of tert-Butyl (4-chlorophenyl) sulfane (27) (500 MHz, $\mathrm{CDCl}_{3}$ ):

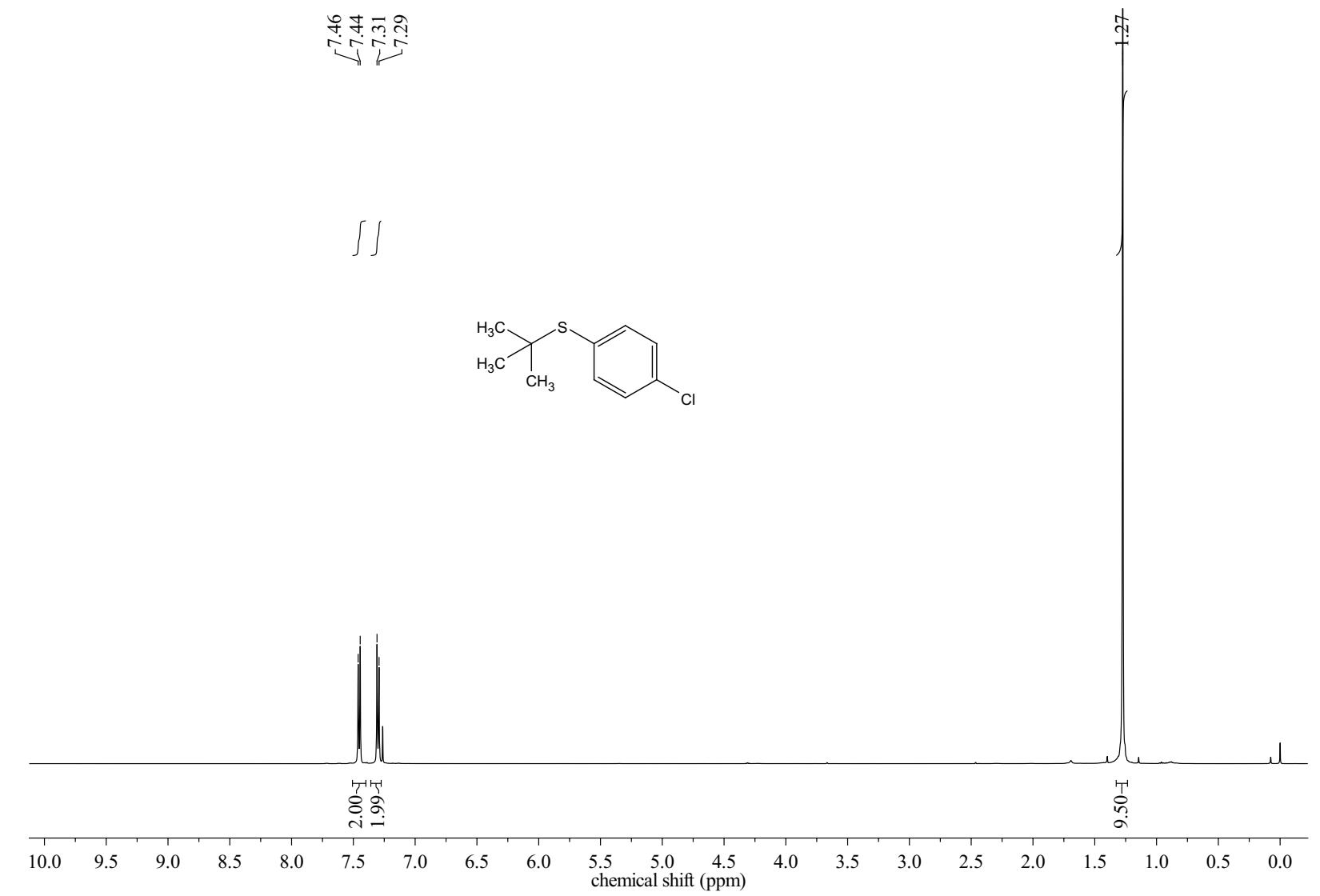

${ }^{13} \mathrm{C}\left\{{ }^{1} \mathrm{H}\right\}$ NMR spectrum of tert-Butyl (4-chlorophenyl) sulfane (27) (125 MHz, $\left.\mathrm{CDCl}_{3}\right)$ :

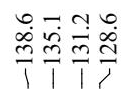

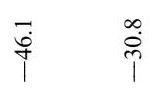

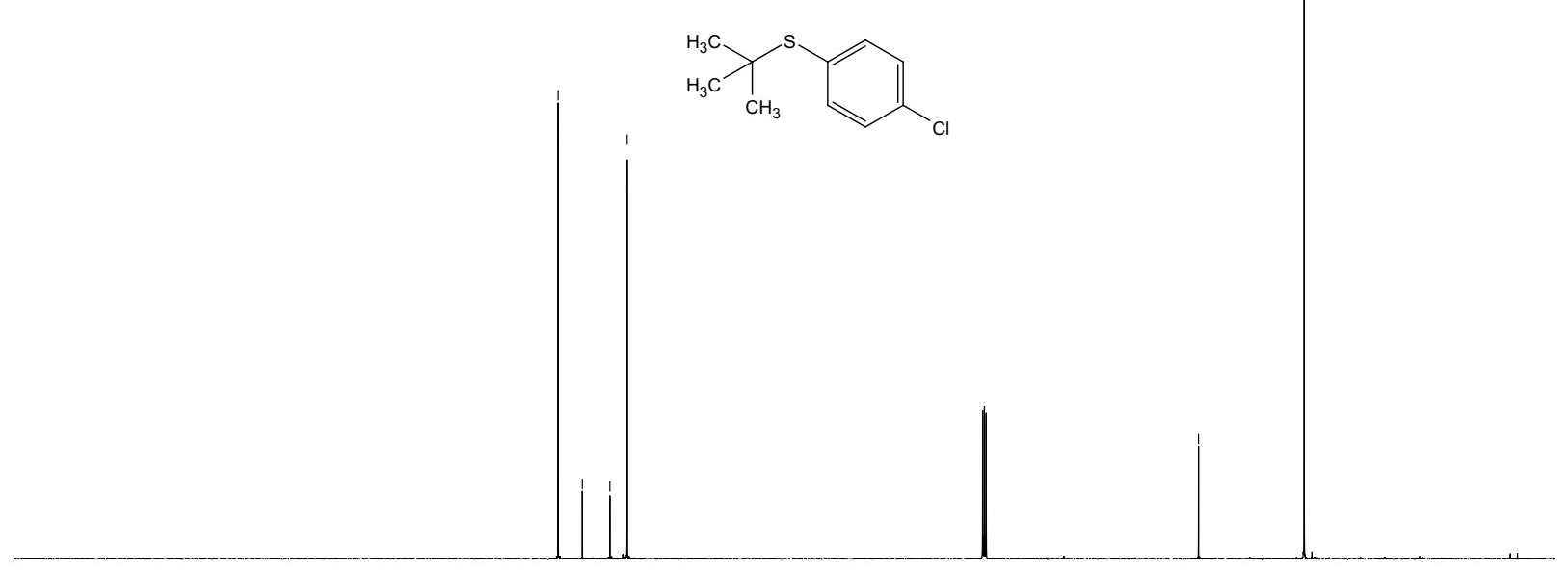

$\begin{array}{llllllllllllllllllllll}210 & 200 & 190 & 180 & 170 & 160 & 150 & 140 & 130 & 120 & 110 & 100 & 90 & 80 & 70 & 60 & 50 & 40 & 30 & 20 & 10 & 0\end{array}$ 
${ }^{1} \mathrm{H}$ NMR spectrum of 1-Adamantyl (4-chlorine)phenyl sulfide (28) (500 MHz, $\mathrm{CDCl}_{3}$ ):

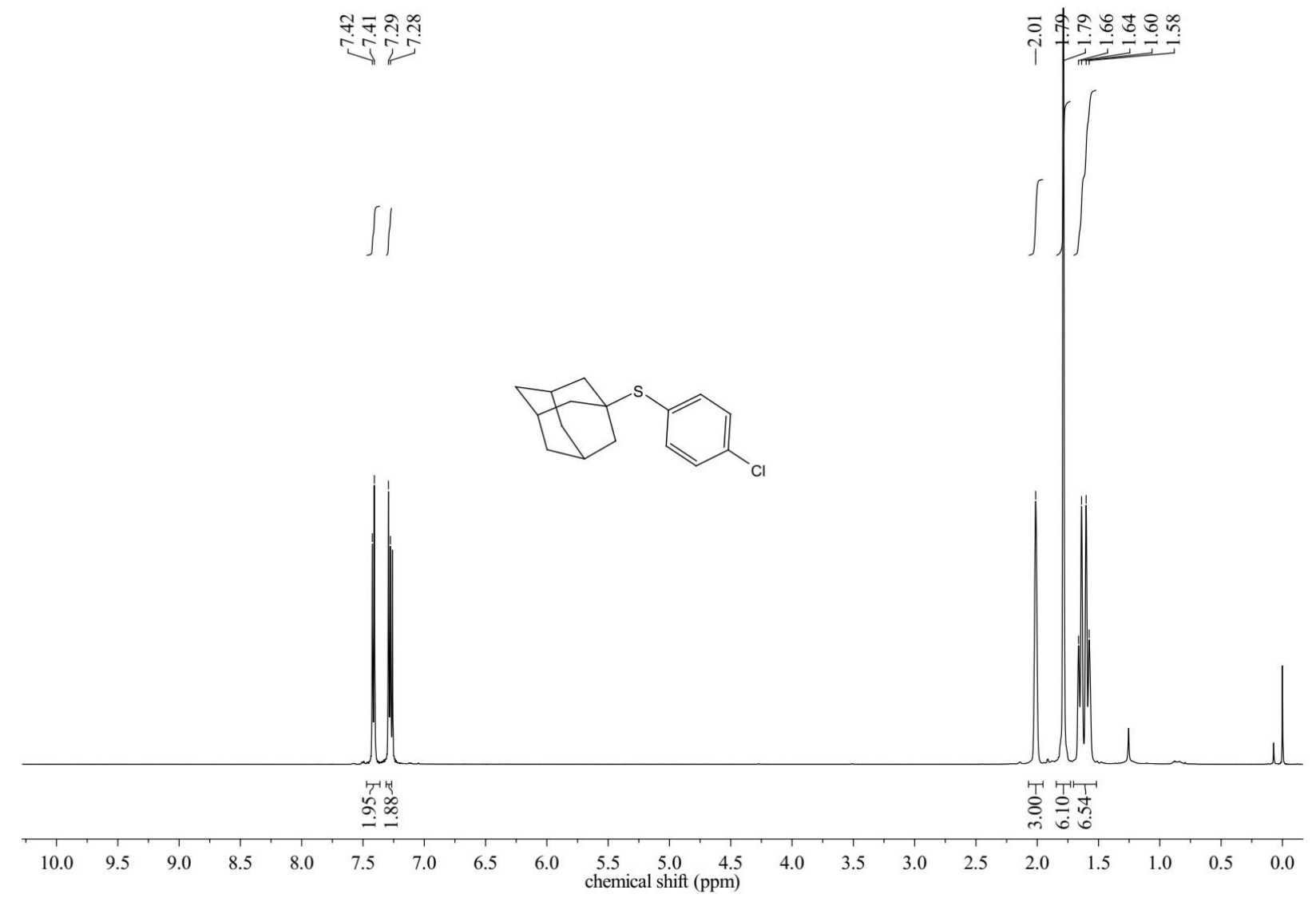

${ }^{13} \mathrm{C}\left\{{ }^{1} \mathrm{H}\right\}$ NMR spectrum of 1-Adamantyl (4-chlorine)phenyl sulfide (28) (125 MHz, $\left.\mathrm{CDCl}_{3}\right)$ :

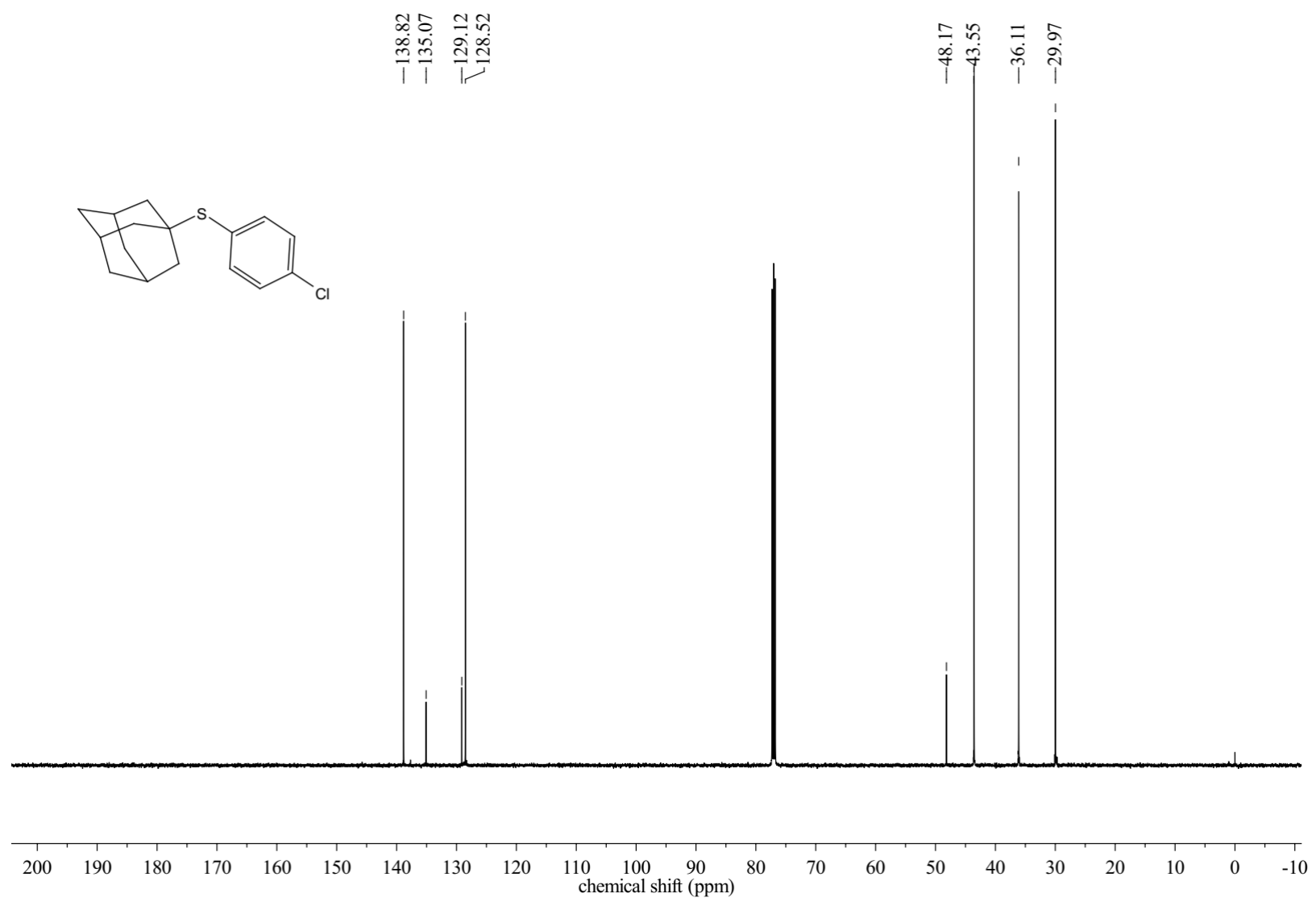


${ }^{1} \mathrm{H}$ NMR spectrum of 4-(Benzo[d]thiazol-2-ylthio) butan-2-one (29) (500 MHz, $\mathrm{CDCl}_{3}$ ):

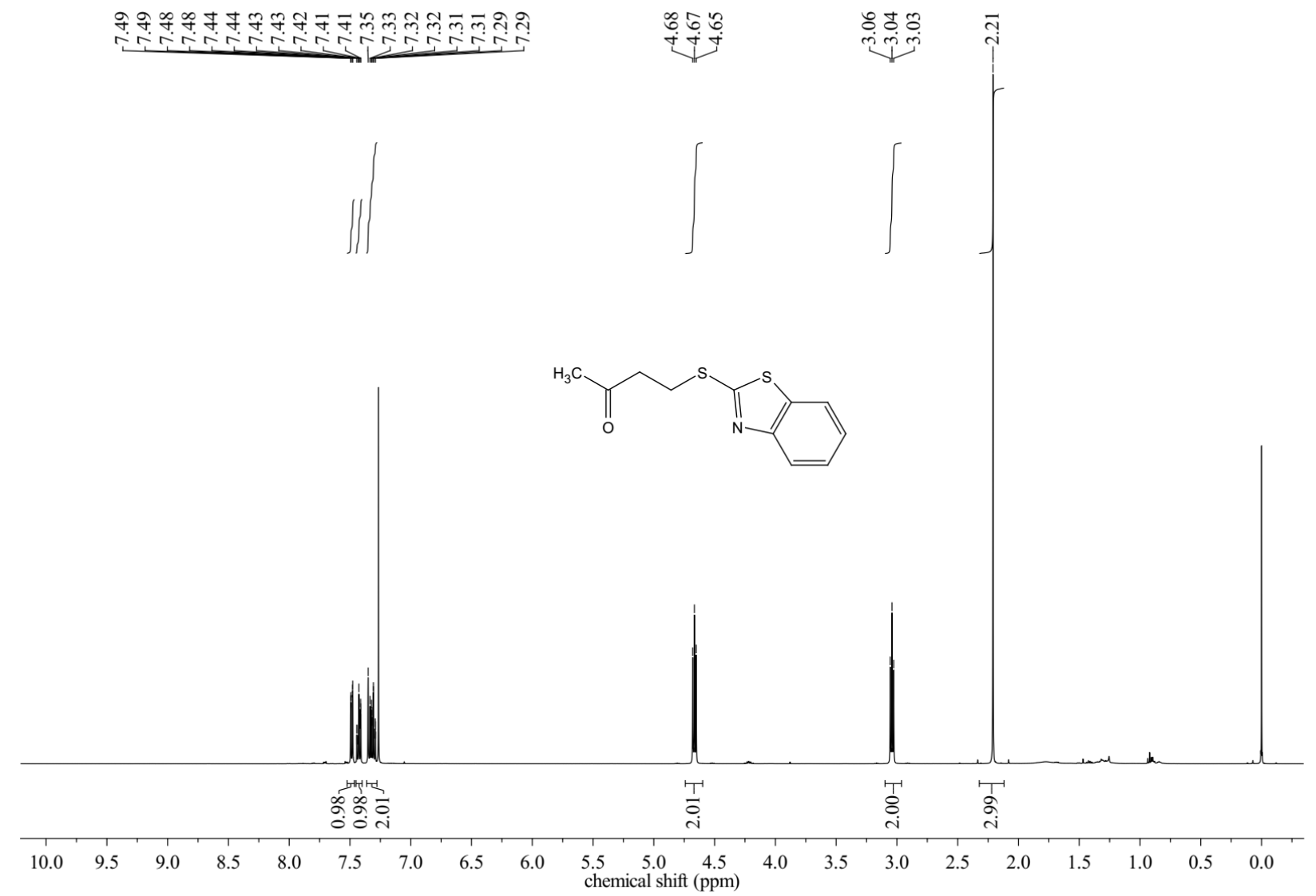

${ }^{13} \mathrm{C}\left\{{ }^{1} \mathrm{H}\right\}$ NMR spectrum of 4-(Benzo[d]thiazol-2-ylthio) butan-2-one (29) $\left(125 \mathrm{MHz}, \mathrm{CDCl}_{3}\right)$ :

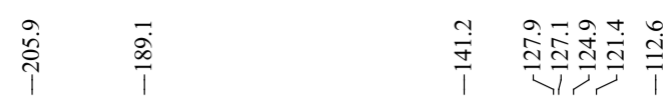

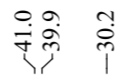
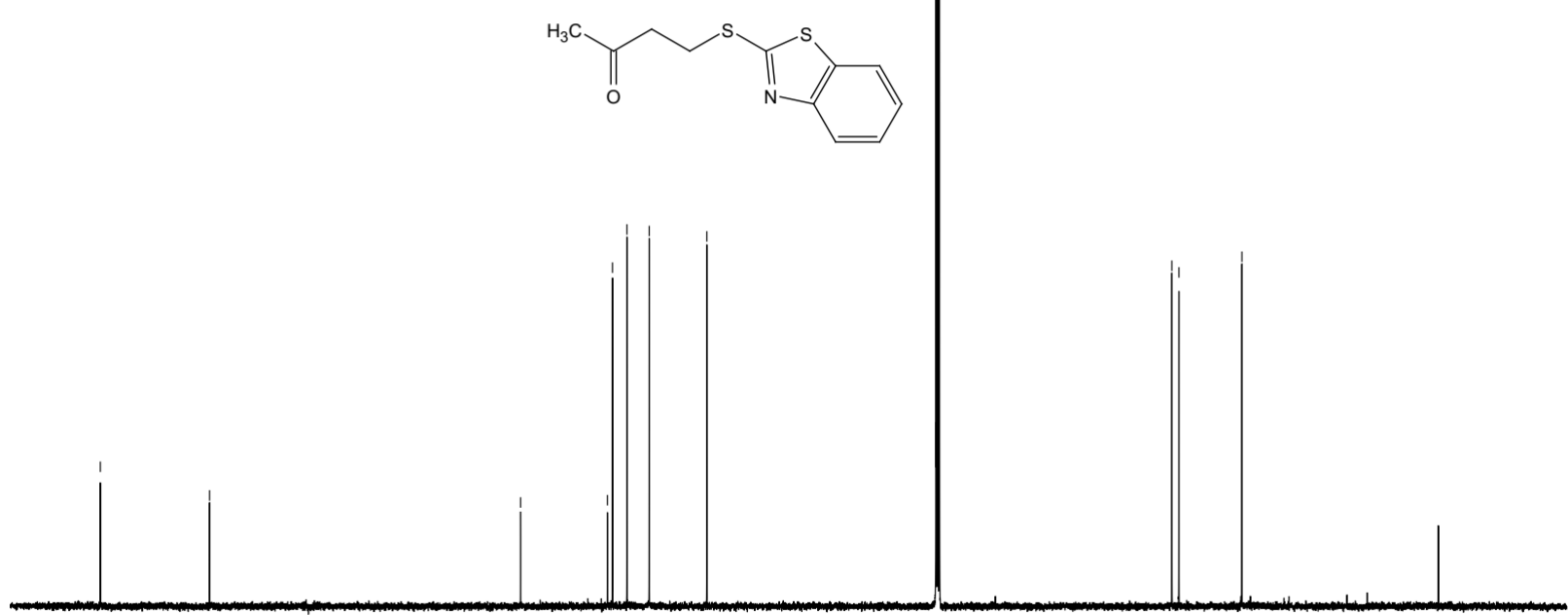

$\begin{array}{lllllllllllllllllllllll}210 & 200 & 190 & 180 & 170 & 160 & 150 & 140 & 130 & 120 & 110 & 100 & 90 & 80 & 70 & 60 & 50 & 40 & 30 & 20 & 10 & 0 & -10\end{array}$ 
${ }^{1} \mathrm{H}$ NMR spectrum of 2-((4-Bromophenethyl) thio) benzo[d] thiazole (30) $\left(400 \mathrm{MHz}, \mathrm{CDCl}_{3}\right)$ :

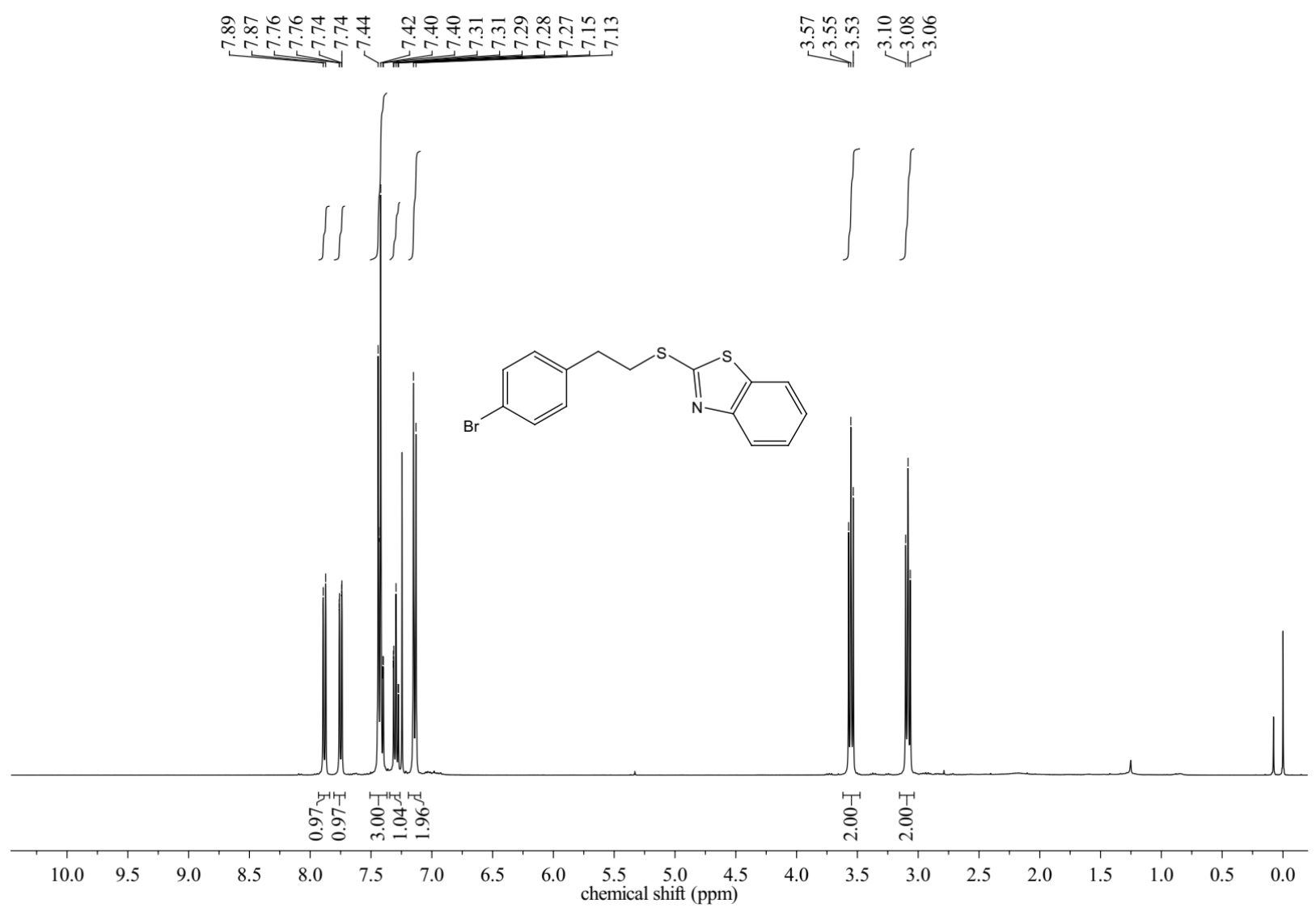

${ }^{13} \mathrm{C}\left\{{ }^{1} \mathrm{H}\right\}$ NMR spectrum of 2-((4-Bromophenethyl) thio) benzo $[d]$ thiazole (30) $\left(100 \mathrm{MHz}, \mathrm{CDCl}_{3}\right)$ :

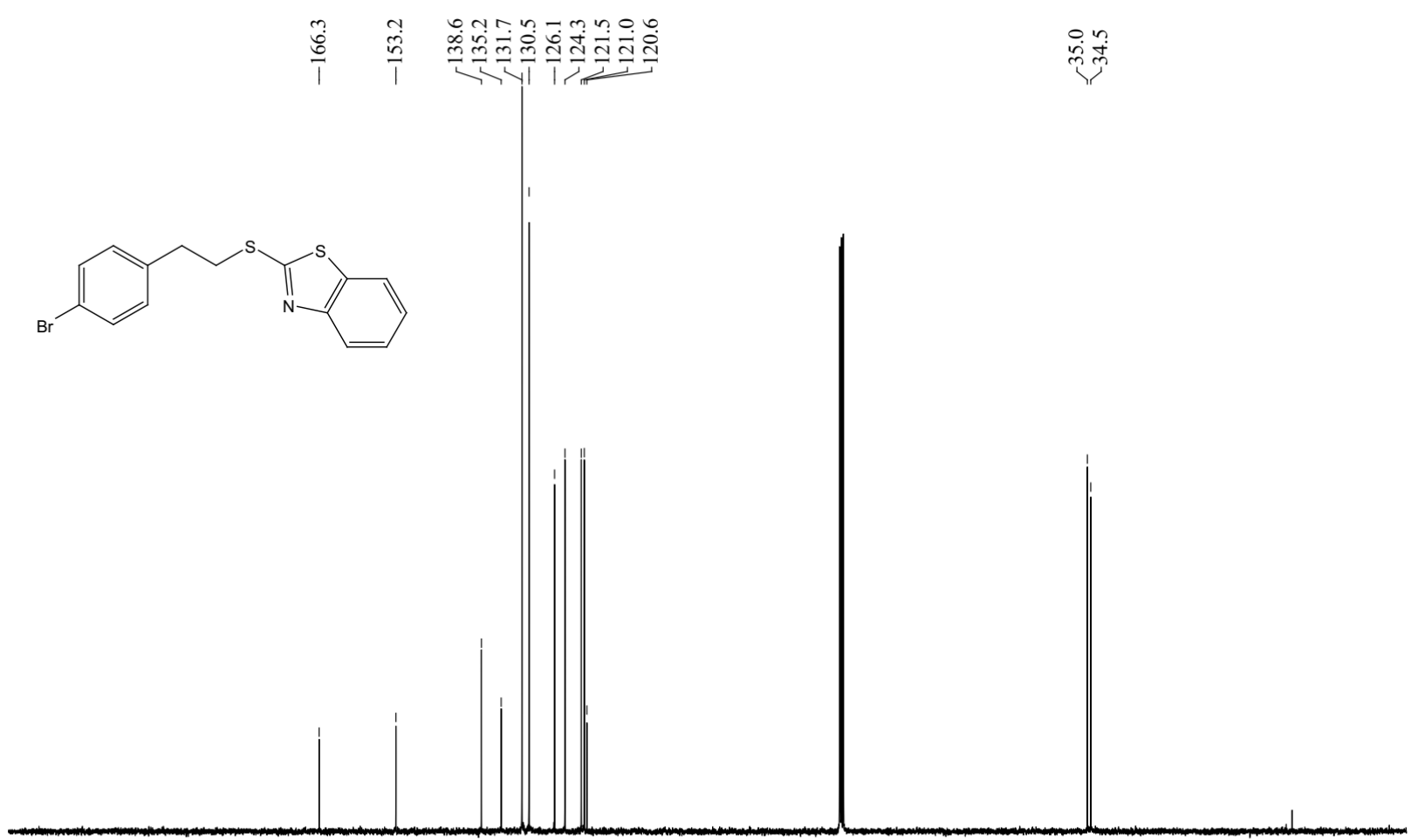

$\begin{array}{lllllllllllllllllllllll}210 & 200 & 190 & 180 & 170 & 160 & 150 & 140 & 130 & 120 & 110 & 100 & 90 & 80 & 70 & 60 & 50 & 40 & 30 & 20 & 10 & 0 & -10\end{array}$ 
${ }^{1} \mathrm{H}$ NMR spectrum of 4-((4-Bromophenethyl) thio) pyridine (31) $\left(500 \mathrm{MHz}, \mathrm{CDCl}_{3}\right)$ :

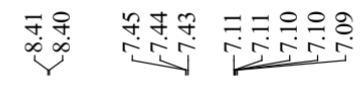

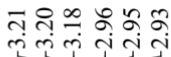
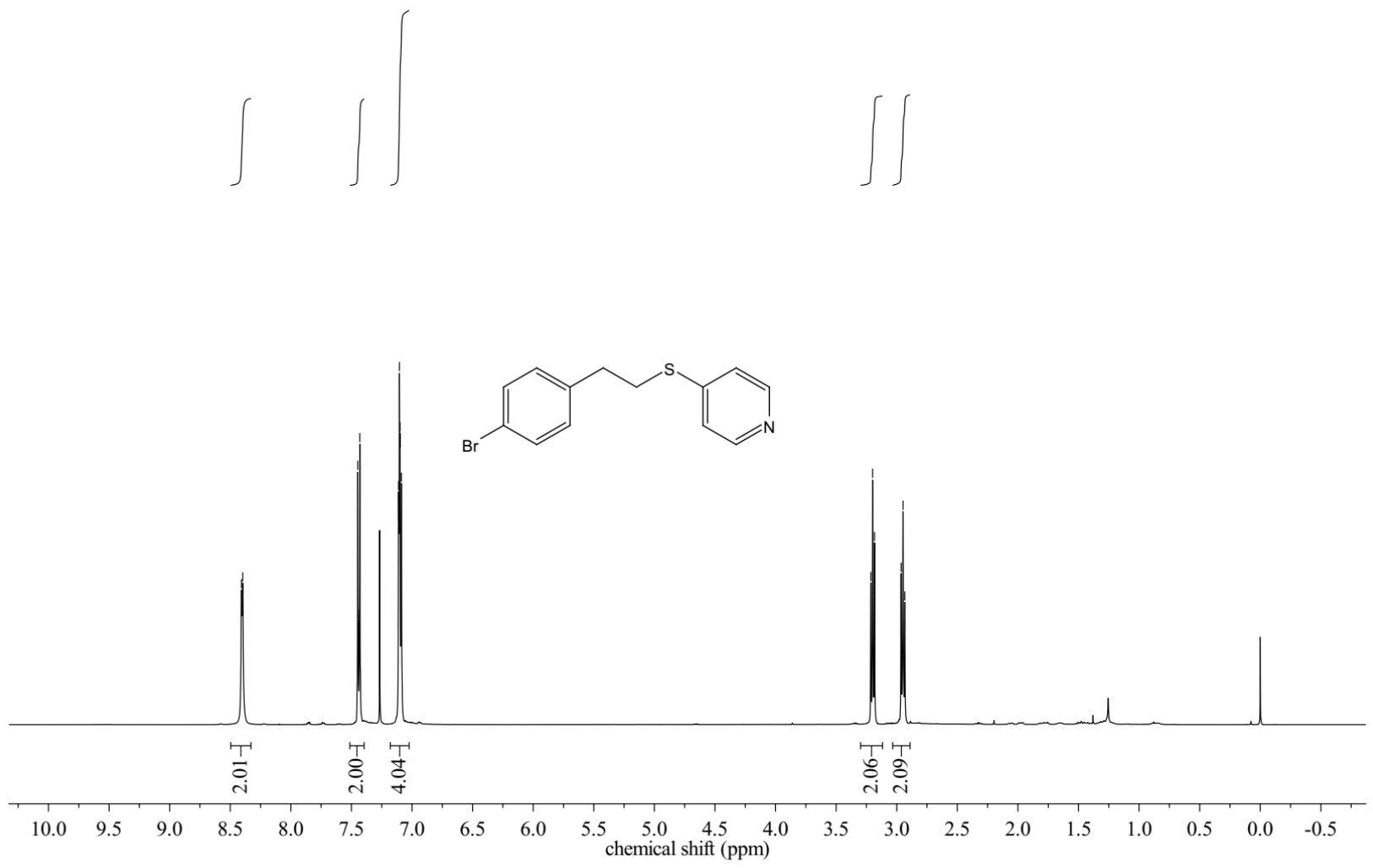

${ }^{13} \mathrm{C}\left\{{ }^{1} \mathrm{H}\right\}$ NMR spectrum of 4-((4-Bromophenethyl) thio) pyridine (31) $\left(125 \mathrm{MHz}, \mathrm{CDCl}_{3}\right)$ :

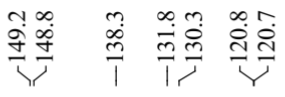
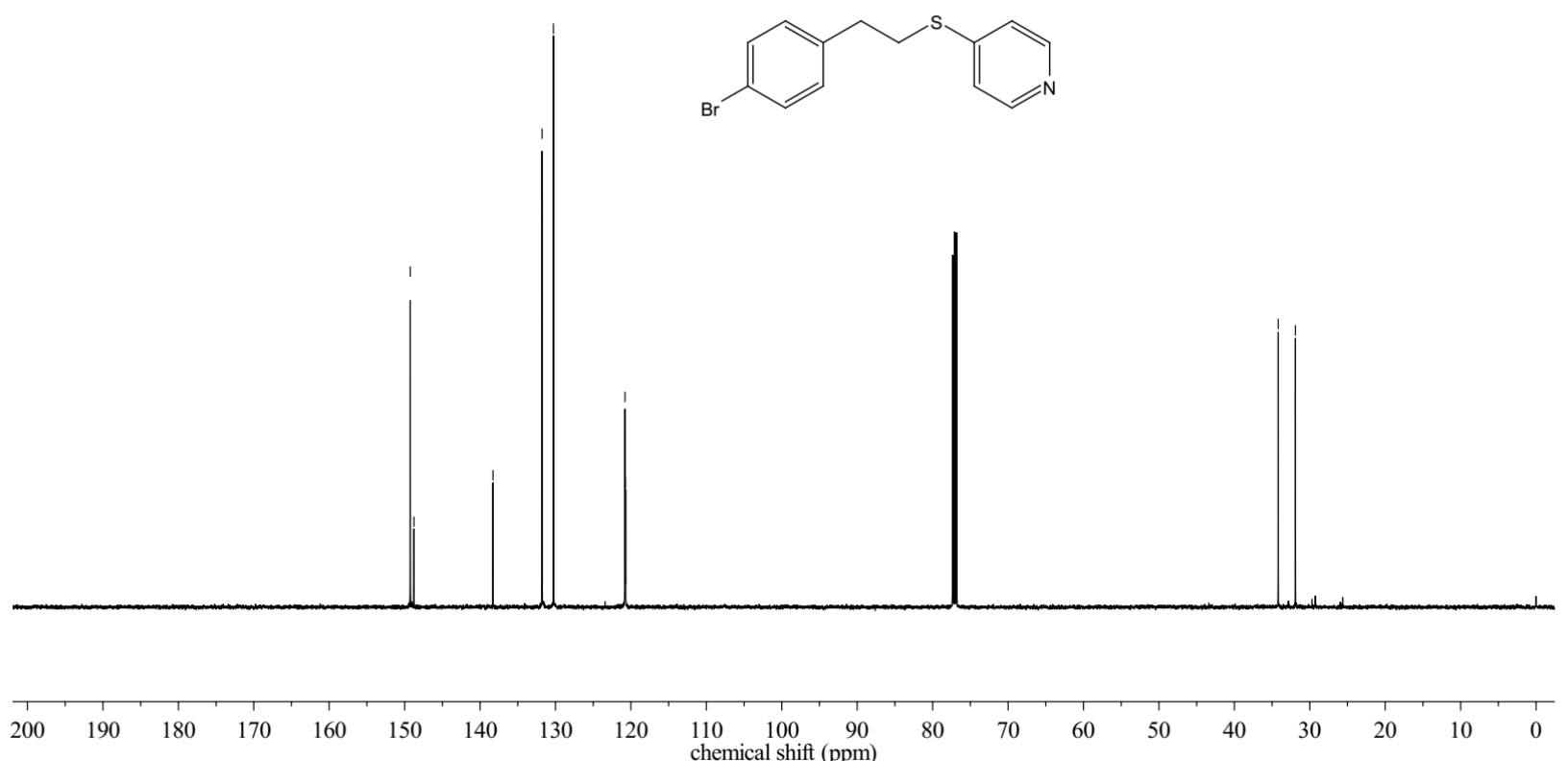
${ }^{1} \mathrm{H}$ NMR spectrum of tert-Butyl 3-(benzo[d]thiazol-2-ylthio) piperidine-1-carboxylate (32) (500 MHz, $\left.\mathrm{CDCl}_{3}\right)$ :

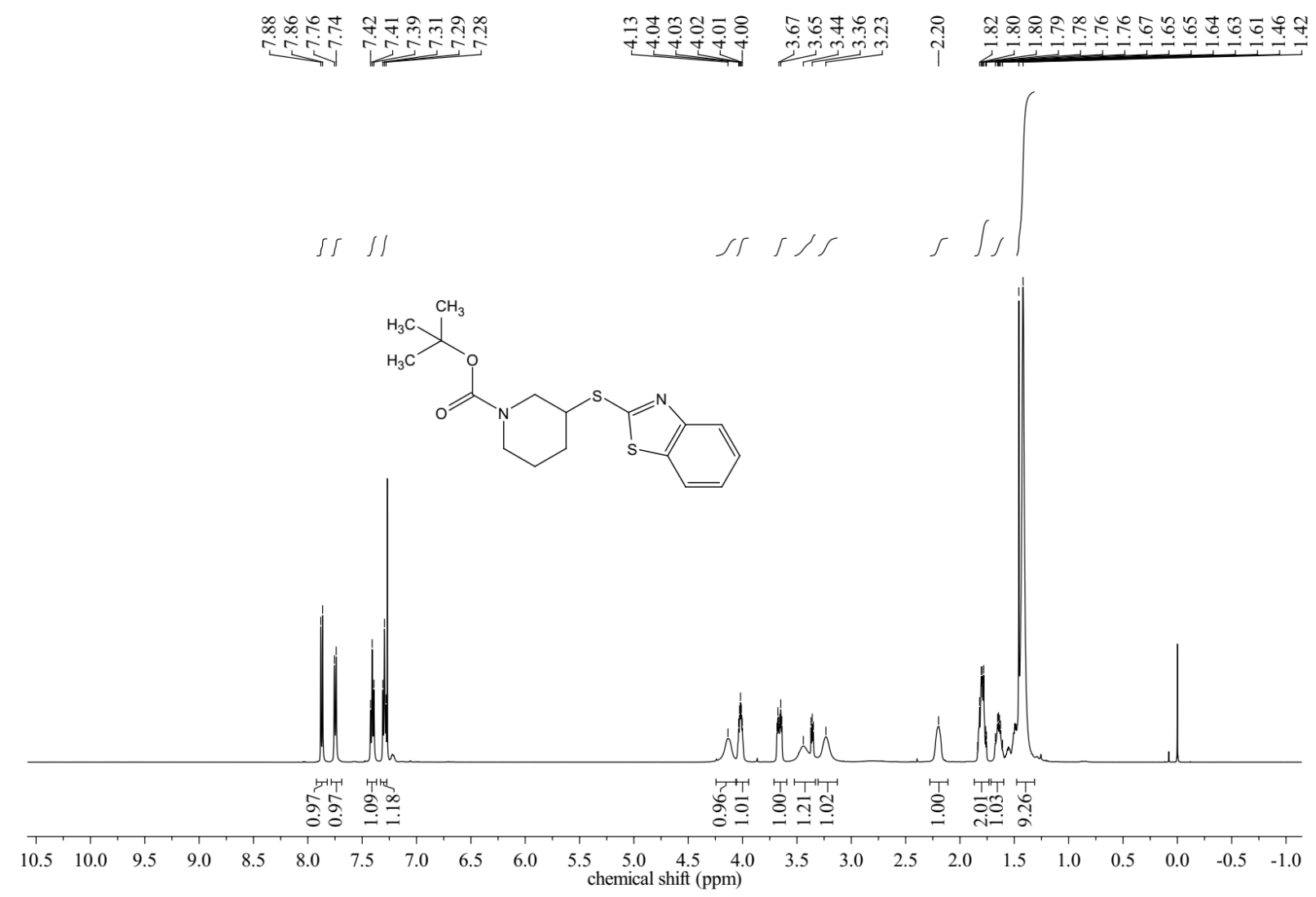

${ }^{13} \mathrm{C}\left\{{ }^{1} \mathrm{H}\right\}$ NMR spectrum of tert-Butyl 3-(benzo[d]thiazol-2-ylthio) piperidine-1-carboxylate (32) $(125 \mathrm{MHz}$, $\left.\mathrm{CDCl}_{3}\right)$ :

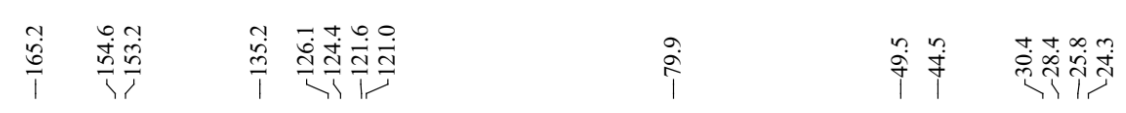
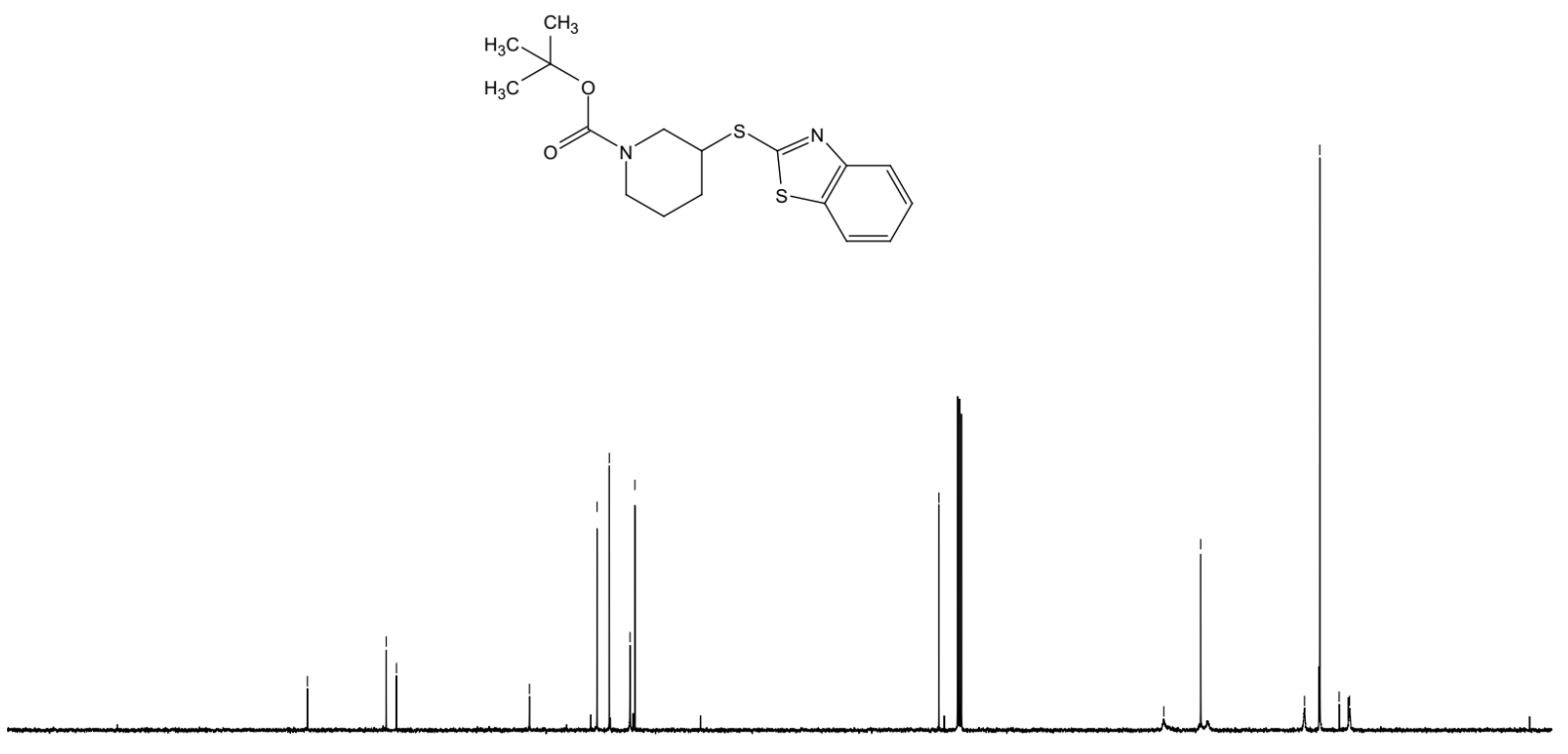

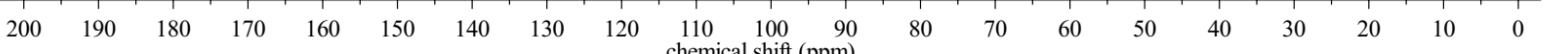


${ }^{1} \mathrm{H}$ NMR spectrum of tert-Butyl 4-(benzo[d]thiazol-2-ylthio) piperidine-1-carboxylate (33) $\left(400 \mathrm{MHz}, \mathrm{CDCl}_{3}\right)$ :

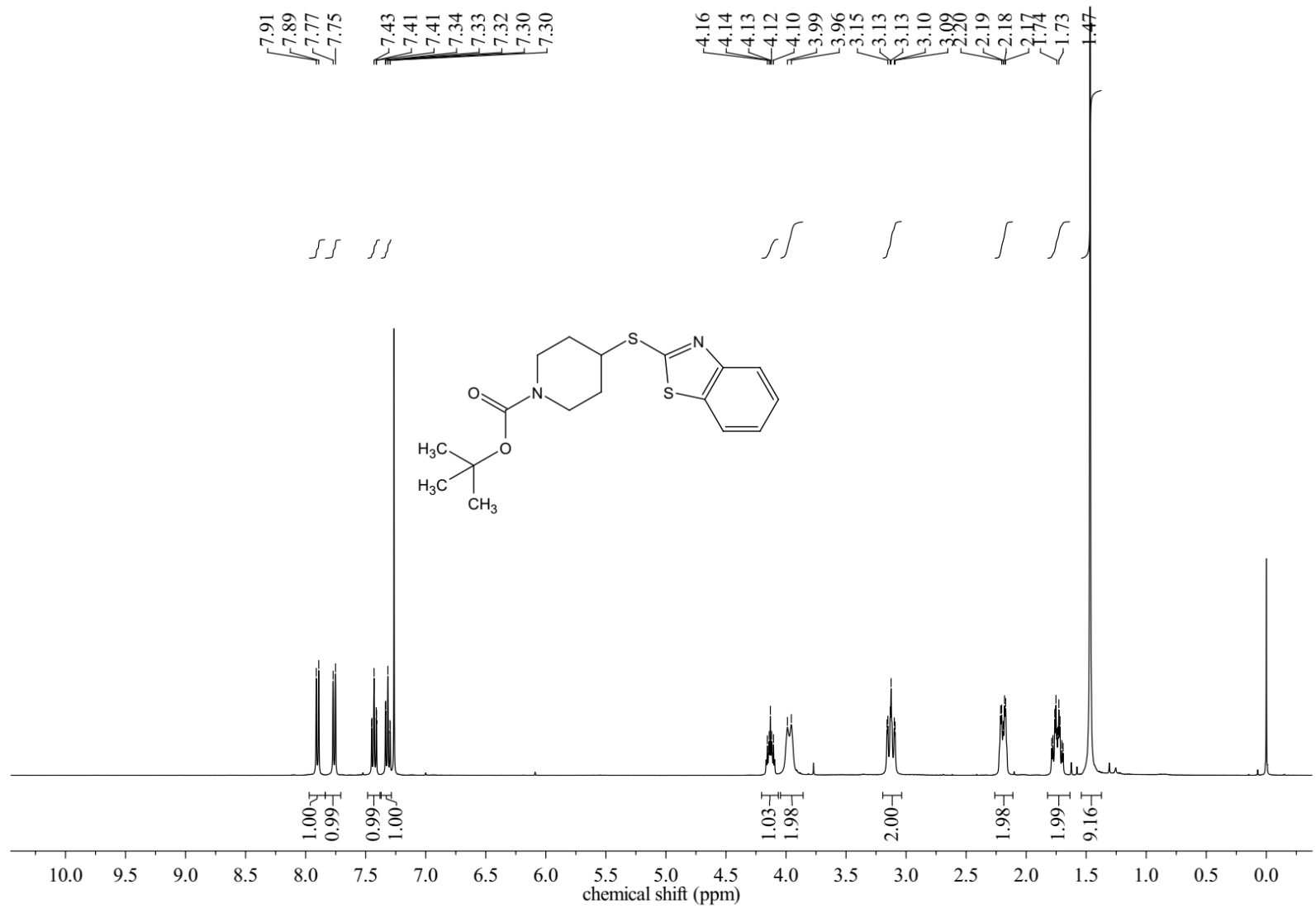

${ }^{13} \mathrm{C}\left\{{ }^{1} \mathrm{H}\right\}$ NMR spectrum of tert-Butyl 4-(benzo[ $[d]$ thiazol-2-ylthio) piperidine-1-carboxylate (33) $(100 \mathrm{MHz}$, $\left.\mathrm{CDCl}_{3}\right)$ :

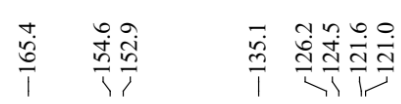
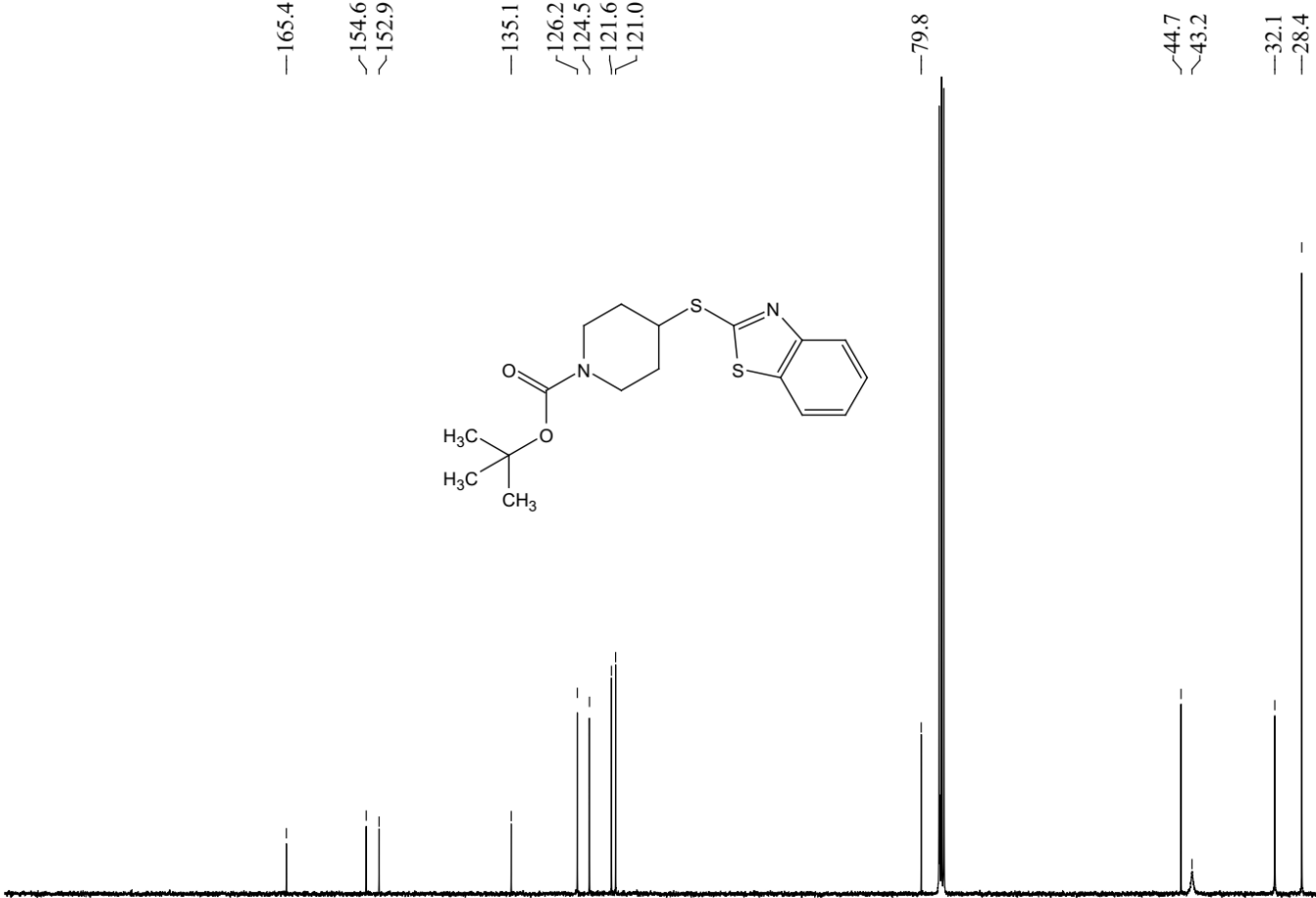

$\begin{array}{lllllllllll}200 & 190 & 180 & 170 & 160 & 150 & 140 & 130 & 120 & 110 & 100 \\ \text { chemical shift (ppm) }\end{array}$ 